Article

\title{
Petrogenesis of Lava from Christmas Island, Northeast Indian Ocean: Implications for the Nature of Recycled Components in Non-Plume Intraplate Settings
}

\author{
Trevor J. Falloon ${ }^{1, *(\mathbb{D}}$, Kaj Hoernle ${ }^{2,3} \mathbb{D}$, Bruce F. Schaefer ${ }^{4}$, Ilya N. Bindeman ${ }^{5}$, Stanley R. Hart ${ }^{6}$, \\ Dieter Garbe-Schonberg ${ }^{3}(\mathbb{D})$ and Robert A. Duncan ${ }^{7}$
}

Citation: Falloon, T.J.; Hoernle, K.; Schaefer, B.F.; Bindeman, I.N.; Hart, S.R.; Garbe-Schonberg, D.; Duncan, R.A. Petrogenesis of Lava from Christmas Island, Northeast Indian Ocean: Implications for the Nature of Recycled Components in Non-Plume Intraplate Settings. Geosciences 2022, 12, 118. https://doi.org/10.3390/ geosciences 12030118

Academic Editors: Paul A. Mueller and Jesus Martinez-Frias

Received: 2 December 2021 Accepted: 28 February 2022 Published: 3 March 2022

Publisher's Note: MDPI stays neutral with regard to jurisdictional claims in published maps and institutional affiliations.

Copyright: (c) 2022 by the authors. Licensee MDPI, Basel, Switzerland. This article is an open access article distributed under the terms and conditions of the Creative Commons Attribution (CC BY) license (https:// creativecommons.org/licenses/by/ $4.0 /)$.
1 School of Natural Sciences, College of Sciences and Engineering, University of Tasmania, Hobart, TAS 7001, Australia

2 GEOMAR Helmholtz Centre for Ocean Research Kiel, Wischhofstrasse 1-3, 24148 Kiel, Germany; khoernle@geomar.de

3 Institute for Geosciences, Kiel University, Ludewig-Meyn-Str. 10, 24118 Kiel, Germany; dieter.garbe-schoenberg@ifg.uni-kiel.de

4 Department of Earth and Planetary Sciences, Macquarie University, Sydney, NSW 2109, Australia; bruce.schaefer@mq.edu.au

5 Department of Earth Sciences, 1272 University of Oregon, Eugene, OR 97403, USA; bindeman@uoregon.edu

6 Department of Geology and Geophysics, Woods Hole Oceanographic Institution, Woods Hole, Falmouth, MA 02543, USA; shart@whoi.edu

7 College of Earth, Ocean, and Atmospheric Sciences, Oregon State University, Corvallis, OR 97333, USA; bob.duncan@oregonstate.edu

* Correspondence: trevor.falloon@utas.edu.au

\begin{abstract}
Lava samples from the Christmas Island Seamount Province (CHRISP) record an extreme range in enriched mantle (EM) type $\mathrm{Sr}-\mathrm{Nd}-\mathrm{Pb}-\mathrm{Hf}$ isotope signatures. Here we report osmium isotope data obtained on four samples from the youngest, Pliocene petit-spot phase (Upper Volcanic Series, UVS; 4.4 Ma), and four samples from the earlier, Eocene (Lower Volcanic Series, LVS; 40 Ma) shield building phase of Christmas Island. Osmium concentrations are low (5-82 ppt) with initial Os isotopic values $\left({ }^{187} \mathrm{Os} /{ }^{188} \mathrm{Os}_{\mathrm{i}}\right)$ ranging from $(0.1230-0.1679)$. Along with additional new geochemical data (major and trace elements, $\mathrm{Sr}-\mathrm{Nd}-\mathrm{Pb}$ isotopes, olivine $\delta^{18} \mathrm{O}$ values), we demonstrate the following: (1) The UVS is consistent with melting of shallow Indian mid-ocean ridge basalt (MORB) mantle enriched with both lower continental crust (LCC) and subcontinental lithospheric mantle (SCLM) components; and (2) The LVS is consistent with recycling of SCLM components related to Gondwana break-up. The SCLM component has FOZO or HIMU like characteristics. One of the LVS samples has less radiogenic Os ( $\gamma$ Os -3.4$)$ and provides evidence for the presence of ancient SCLM in the source. The geochemistry of the Christmas Island lava series supports the idea that continental breakup causes shallow recycling of lithospheric and lower crustal components into the ambient MORB mantle.
\end{abstract}

Keywords: osmium isotopes; petit-spot volcanism; olivine oxygen isotopes; intraplate volcanism; Christmas Island; Indian Ocean; CHRISP; crust recycling; lithosphere recycling; DUPAL

\section{Introduction}

A fundamental question concerns the origin of the hundreds of thousands of solitary seamounts and small isolated clusters of such seamounts on the seafloor of the world's ocean basins (>20,000 at least $1 \mathrm{~km}$ high; [1]). Most of them are not directly associated with age-progressive hotspot tracks and are therefore difficult to explain within the classic mantle plume model [2-7]. They could be the result of shallow tectonically driven processes, and several models have been proposed (e.g., [8-14]), or alternatively the result of smaller scale mantle plumes (e.g., $[15,16])$. To gain a better understanding of magmatism associated with 
enigmatic non-plume intraplate settings it is essential to provide petrogenetic constraints on the nature of mantle sources and melts in these settings. Christmas Island located in the northeast Indian Ocean $\left(10^{\circ} 29^{\prime} \mathrm{S} 105^{\circ} 38^{\prime} \mathrm{E}\right.$; Figure 1) is an ideal subject for investigation as it belongs to the extensive but diffuse Christmas Island Seamount Province (CHRISP, Figures 1 and S1; [10]), which shows no relationship to any mantle plume but instead shows complex, irregular age-distance relationships (Figure S1; [10]).

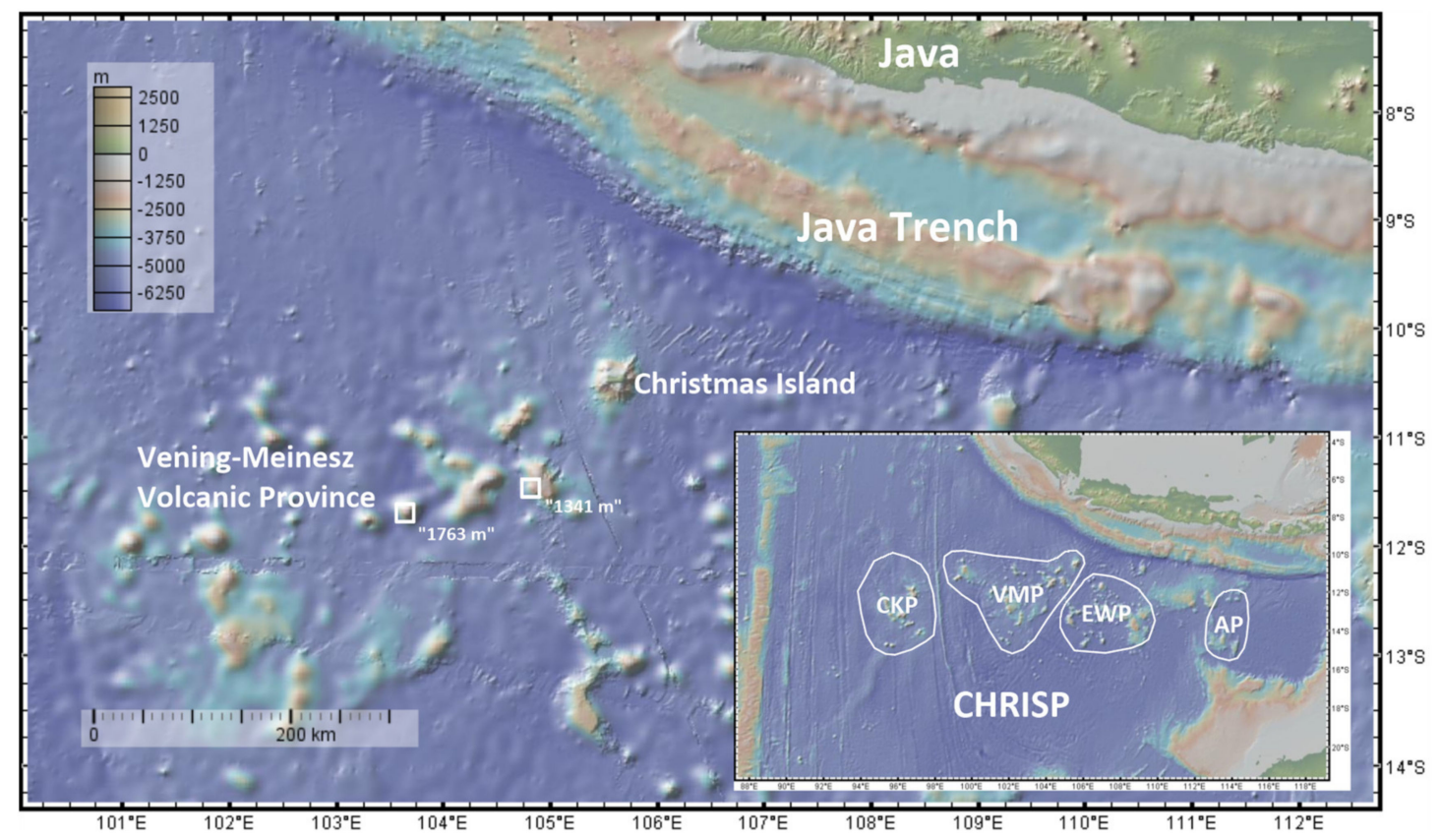

Figure 1. Bathymetric map of the NE Indian Ocean showing the location of Christmas Island. White squares show the locations of seamounts " $1763 \mathrm{~m}$ " and "1341 m" of the Vening-Meinesz Volcanic Province (VMP). Inset shows the volcanic sub-provinces of CHRISP [10] as follows: AP, Argo Basin volcanic province; EWP, Eastern Wharton Basin volcanic province; VMP, Vening-Meinesz volcanic province and CKP, Cocos-Keeling volcanic province. Map generated by GeoMapApp [17].

In addition, Christmas Island has a young (lower Pliocene) rejuvenated lava series (the upper volcanic series UVS, [10]) significantly younger than an older (upper Eocene) lava series (the lower volcanic series LVS, [10]). Rejuvenated magmatism is an enigmatic feature of intraplate volcanism in general [18-24] which is also difficult for a mantle plume model to explain in all cases.

In the case of the rejuvenated lava of Christmas Island, Hoernle et al. [10] proposed that they could be the result of lithospheric plate flexure as the Indian Plate is subducted at the Java Trench $[25,26]$ and therefore has a similar origin to the newly recognized intraplate volcanism referred to as 'petit-spot' occurring out board of oceanic trenches at the fore-bulge of the down-going subducting oceanic plate [24,27]. Hoernle et al. [10] demonstrated that the ${ }^{40} \mathrm{Ar} /{ }^{30} \mathrm{Ar}$ ages and isotopic ( $\mathrm{Sr}-\mathrm{Nd}-\mathrm{Hf}-\mathrm{Pb}$ ) compositions of dredged volcanic rocks from CHRISP were consistent with a petrogenetic model involving nearridge volcanism and shallow recycling of delaminated continental lithosphere (related to Gondwana supercontinent break-up). One of the aims of this paper is to test whether the model of Hoernle et al. [10] is also applicable to the lava from both the Eocene (LVS) and lower Pliocene (LVS) volcanic series of Christmas Island [10], by determining the osmium isotopic ( ${ }^{187} \mathrm{Os} /{ }^{188} \mathrm{Os}$ ) values on relatively unaltered (fresh) lavas. The presence of continental lithosphere should be evident in low ${ }^{187} \mathrm{Os} /{ }^{188} \mathrm{Os}$ and sub-chondritic $\gamma \mathrm{Os}_{\mathrm{i}}$ values $\left(\gamma \mathrm{Os}_{\mathrm{i}}\right.$ is the parts per 100 difference between the sample and chondrite-0.12757 [28] calculated at the age of the sample [29]) in the erupted lava [28,30-35]. 
Along with osmium isotopic analyses we present whole rock and mineral geochemistry (major and trace elements, $\mathrm{Sr}-\mathrm{Nd}-\mathrm{Pb}$ isotopes, and olivine phenocryst $\delta 18 \mathrm{O}$ values) of the Christmas Island lava series to provide petrogenetic constraints on the nature of mantle sources, and PTX (pressure, temperature, composition) conditions of melt generation. We also present whole rock geochemical and isotopic data for volcanic rocks from two seamounts of the Cretaceous-aged Vening-Meinesz volcanic sub-province (VMP) of CHRISP (Figures 1 and S1) to the southwest of Christmas Island sampled by dredging during voyage FR9_87 of the RV Franklin. In summary, our data supports the model of Hoernle et al. [10] and provides new petrogenetic constraints on the origin of non-plume intraplate magmatism and the nature of enriched DUPAL components in the Indian Oceanic mantle. DUPAL is the name which refers to a large-scale isotope anomaly in the southern hemisphere mantle centered on latitude $30^{\circ} \mathrm{S}$ [36]. Details on the geology of Christmas Island and our sampling are provided in the Supplementary Discussion.

\section{Methods}

\section{1. ${ }^{40} \mathrm{Ar}-39$ Ar Radiometric Dating}

We selected two relatively unaltered lava samples from the LVS and three from the UVS for radiometric dating (Table 1, Figure S2) using the ${ }^{40} \mathrm{Ar}^{-39} \mathrm{Ar}$ total fusion method. The least-altered, well-crystallized samples were slabbed to remove surface weathering, crushed and sieved to $0.5-1.0 \mathrm{~mm}$-size fraction, then ultrasonically washed in distilled water. We separated the groundmass fraction from phenocrysts by hand-picking under binocular microscope. The cleaned groundmass chips were loaded into evacuated glass vials and irradiated in a flux of fast neutrons (1 MW power for $6 \mathrm{hr}$ ) at the Oregon State University TRIGA reactor. We used FCT-3 biotite standard (28.04 Ma; [37]) to monitor neutron flux. Corrections for interfering reactions involving $\mathrm{Ca}$ and $\mathrm{K}$ are given in [38]. After the decay of short-lived radionuclides ( $\sim 3$ weeks) we measured the Ar-isotopic composition of the samples using an AEI MS-10S single-collector mass spectrometer, with RF-induction fusion under vacuum and Ti-getter gas clean-up. We collected 10 sets of Ar-isotopic peak heights and regressed these with time to obtain initial isotopic ratios. We calculated the ages using the corrected Steiger and Jager [39] decay constant of $5.530 \pm 0.097 \times 10^{-10} / \mathrm{yr}$, as reported by [40]. Further analytical details are provided in [41]. $\mathrm{All}^{40} \mathrm{Ar}^{-39} \mathrm{Ar}$ ages are reported at the $2 \mathrm{~s}$ level. Table 1 summarizes the results of our new geochronological data.

Table 1. ${ }^{40} \mathrm{Ar}^{-39} \mathrm{Ar}$ Total Fusion Ages for Christmas Island volcanic rocks.

\begin{tabular}{|c|c|c|c|c|c|}
\hline Sample & OSU Run\# & $\%$ rad. ${ }^{40} \mathrm{Ar}$ & Measured Age (Ma) & $2 \sigma$ Errors & Locality \\
\hline \multicolumn{6}{|c|}{ Lower Volcanic Series } \\
\hline 70452 & B3009 & 47.0 & 40.10 & 0.30 & The Dales \\
\hline 70480 & B3016 & 73.8 & 40.70 & 0.20 & Dolly Beach \\
\hline \multicolumn{6}{|c|}{ Upper Volcanic Series } \\
\hline 70457 & B3011 & 49.2 & 5.08 & 0.30 & Winifried Beach \\
\hline 70461 & B3012 & 41.6 & 4.95 & 0.06 & Winifried Beach \\
\hline 70462 & B3013 & 57.4 & 3.06 & 0.14 & Winifried Beach \\
\hline
\end{tabular}

\subsection{Mineral Chemistry}

The mineralogy of representative lava from both the LVS and UVS were analyzed using either EDS (energy dispersive spectroscopy) or WDS (wavelength dispersive spectroscopy) microprobe techniques. The compositions of representative phenocryst and groundmass phases are presented in Table S3. For the three representative primitive lava (LVS samples 70480 and 70470 and UVS sample 70453), olivine and clinopyroxene were hand-picked under binocular microscope and individually mounted in epoxy before analysis (Table S4). EDS analyses (Table S3) were obtained using a Jeol JXA-50A microprobe at the Central Science laboratory, University of Tasmania (UTAS), Hobart (operating conditions $15 \mathrm{kV}$, $7 \times 10^{-10} \mathrm{~A}$, calibration was on pure $\mathrm{Cu}$ ) following the methods outlined by [42]. Internal 
standard "Delegate Cpx" was used to monitor beam current and analysis quality. WDS analyses of olivine and clinopyroxene (Table S4) were obtained using a Cameca SX100 electron microprobe at the Central Science laboratory, University of Tasmania, Hobart (operating conditions $15 \mathrm{kV}$ and $30 \eta \mathrm{A}$ and a beam size of $1-2 \mu \mathrm{m}$ ). Each element was calibrated against a relevant oxide standard. Counting times for $\mathrm{Mg}, \mathrm{Si}, \mathrm{Al}$ and Fe was $20 \mathrm{~s}$ for the peak and $10 \mathrm{~s}$ for the background on both sides of the peak. Counting times for $\mathrm{Ca}, \mathrm{Cr}$ and $\mathrm{Ni}$ were $30 \mathrm{~s}$ for the peak and $15 \mathrm{~s}$ for the background on both sides of the peak. International standard USNM 111312/444 (San Carlos olivine) was used as primary standard and analyzed throughout analytical sessions. The accuracy of the electron microprobe analyses is $\sim 2 \%$ for major elements

\subsection{Whole Rock Geochemistry}

The geochemistry of rock samples from the FR9_87 RV Franklin voyage (Table S1), the 1987 field season (Table S2) and from [43] were determined either at the University of Tasmania or Becquerel Laboratories Pty Ltd., Sydney, Australia using the following techniques: (1) major elements were determined by XRF (X-ray fluorescence) using an automated Phillips PW1410 spectrometer, and the method of [44]. Accuracy for major elements is generally $<1 \%$ while for minor elements it is $<1-6 \%$; (2) trace element geochemistry was determined by XRF, ICP-MS (inductively coupled plasma mass spectrometry) and INAA (instrumental neutron activation analysis) analyses. XRF analyses were determined on pressed powder pills (10 grams, $32 \mathrm{~mm}$ ) using a combination of ScMo and Au $3 \mathrm{~kW}$ side window X-ray tubes and a Philips PW1480 x-ray spectrometer. Analyses of international and secondary standards and detection limits are presented in Table S5. ICP-MS trace element analyses were obtained using the methods of $[45,46]$. ICP-MS analyses were performed on duplicate high-pressure $\mathrm{HF}^{-\mathrm{HClO}_{4}}$ digestions. Sub-boiling double distilled acids and ultrapure water were used, as were clean sampler and skimmer cones, ICP torch, spray chamber, nebulizer and sample introduction tubes (including auto-sampler tubing). Prior to sample analysis the instrument was purged for at least $24 \mathrm{~h}$ with $5 \% v / v \mathrm{HNO}_{3}$ and $0.05 \% v / v$ HF rinse solution. Analyses of standards and detection limits are presented in Table S5. INAA analyses of REE, Th, Ta and Hf were determined by Dr H. Waldron of Becquerel Laboratories Pty Ltd. at Lucas Heights, Sydney, Australia. Detection limits, as assessed from replicate analyses of standard rocks, are as follows: Th, $0.1-0.25$ ppm (depending on length of radiation and counting schedule); Ta, 0.2-0.5 ppm (again depending on length of radiation and counting schedule); Hf, 0.5 ppm; La, 0.1 ppm; Ce, 1.5 ppm; Nd, 2.5 ppm; Sm, 0.05 ppm; Eu, 0.2 ppm; Tb, 0.5 ppm; Ho, 0.5 ppm; Yb, 0.1 ppm; Lu, 0.05 ppm. Accuracy is generally better than $5 \%$ for Th, Ta and Hf and between $5-10 \%$ for the REE. The geochemistry of rock samples from the study of [10] were carried out by Acme Analytical Laboratories Ltd., Vancouver, Canada, using the following techniques:(1) major elements were determined by ICP-ES analysis. A precision of better than $2 \%$ was obtained for major elements; and (2) trace elements were determined by ICP-MS. A precision better than $10 \%$ was achieved for all elements. Analyses of standard rocks are presented in Table S5.

The measured $\mathrm{Sr}, \mathrm{Nd}$, and $\mathrm{Pb}$ isotope compositions (Table 2) were determined at both Massachusetts Institute of Technology and Woods Hole Oceanographic Institution following the analytical techniques described in $[47,48]$. Two sigma precision of the measured isotopic data is $0.0025 \%$ for $\mathrm{Sr}, 0.0020 \%$ for $\mathrm{Nd}$ and $\pm 0.05 \% \mathrm{amu}^{-1}$ for $\mathrm{Pb}$ [49]. The following international standards were used: BCR-1 for neodymium; Eimer and Amend $\mathrm{SrCO}_{3}$ for strontium and NBS-981 for lead. The isotope data on our new samples were determined solely on leached powders, excepting samples 70480 and 70471, for which both leached and unleached powders were analyzed for $\mathrm{Pb}$ isotopes. 
Table 2. $\mathrm{Sr}, \mathrm{Nd}$ and $\mathrm{Pb}$ isotopic composition of volcanic rocks from Christmas Island and dredged by the RV Franklin voyage FR9_87.

\begin{tabular}{|c|c|c|c|c|c|c|c|}
\hline Sample & Lava Series & ${ }^{87} \mathrm{Sr} /{ }^{86} \mathrm{Sr}$ & ${ }^{143} \mathrm{Nd} /{ }^{144} \mathrm{Nd}$ & ${ }^{206} \mathrm{~Pb} /{ }^{204} \mathrm{~Pb}$ & ${ }^{207} \mathrm{~Pb} /{ }^{204} \mathrm{~Pb}$ & ${ }^{208} \mathrm{~Pb} /{ }^{204} \mathrm{~Pb}$ & Leached \\
\hline 70472 & LVS & 0.703980 & 0.512806 & 19.151 & 15.675 & 39.334 & $\mathrm{Y}$ \\
\hline 70480 & LVS & 0.703930 & 0.512724 & 18.915 & 15.637 & 39.071 & $\mathrm{Y}$ \\
\hline 70480 & LVS & & & 18.937 & 15.615 & 39.056 & $\mathrm{~N}$ \\
\hline 70452 & LVS & 0.704090 & 0.512702 & 18.955 & 15.644 & 39.125 & $\mathrm{Y}$ \\
\hline 70471 & LVS & 0.703770 & 0.512827 & 18.918 & 15.577 & 38.784 & $\mathrm{Y}$ \\
\hline 70471 & LVS & & & 18.852 & 15.578 & 38.779 & $\mathrm{~N}$ \\
\hline 70457 & UVS & 0.705360 & 0.512544 & 18.043 & 15.566 & 38.128 & $\mathrm{Y}$ \\
\hline 70453 & UVS & 0.705420 & 0.512498 & 17.846 & 15.566 & 38.071 & Y \\
\hline 70461 & UVS & 0.705390 & 0.512511 & 17.905 & 15.573 & 38.134 & Y \\
\hline 70462 & UVS & 0.705430 & 0.512460 & 17.904 & 15.568 & 38.118 & Y \\
\hline $70488-2$ & VM-1763m & 0.704670 & 0.512452 & 17.979 & 15.639 & 38.478 & $\mathrm{Y}$ \\
\hline $70488-5$ & VM-1763m & 0.704640 & 0.512470 & 17.960 & 15.625 & 38.427 & $\mathrm{Y}$ \\
\hline
\end{tabular}

\subsection{Osmium and Oxygen Isotopes}

Osmium isotopes were determined on representative samples from both the LVS and UVS of Christmas Island (Table 3). Samples that were selected did not contain any xenoliths, clumps of olivine or obviously resorbed olivine that may have suggested xenolithic material. Olivine was relatively small and euhedral to subhedral for all samples for which Os was analyzed. Osmium isotopes were determined using the methods outlined in the Supplementary Discussion. Oxygen isotopes were also determined using the methods outlined in [50] on olivine phenocryst separates from the same samples by laser fluorination -MAT253 system at the University of Oregon (Table 3) and normalized to San Carlos olivine standard at $5.25 \%$ o (analytical error $0.07 \%$ o).

Table 3. Os, Re and O isotopes of Christmas Island volcanic rocks.

\begin{tabular}{|c|c|c|c|c|c|c|c|c|c|c|c|c|c|}
\hline $\begin{array}{c}\text { Sample } \\
\text { No. }\end{array}$ & $\begin{array}{l}\text { Lava } \\
\text { Series }\end{array}$ & $\begin{array}{l}\text { Age } \\
\text { (Ma) }\end{array}$ & $\begin{array}{c}\text { Os } \\
(\mathrm{ppb})\end{array}$ & $2 \sigma$ & ${ }^{187} \mathrm{Os} /{ }^{188} \mathrm{Os}$ & $2 \sigma$ & $\begin{array}{c}\operatorname{Re} \\
(\mathrm{ppb})\end{array}$ & $2 \sigma$ & ${ }^{187} \mathrm{Re} /{ }^{188} \mathrm{Os}$ & $2 \sigma$ & ${ }^{187} \mathrm{Os} /{ }^{188} \mathrm{Os}_{\mathrm{i}}$ & $\gamma\left(\mathrm{Os}_{\mathrm{i}}\right)$ & $\mathcal{\delta}^{18} \mathrm{O}$ \\
\hline CH7B & UVS & 4.4 & 0.0327 & 0.0001 & 0.145560 & 0.000136 & 0.0809 & 0.0012 & 11.94 & 0.01 & 0.144684 & 13.44 & 5.30 \\
\hline CH7B & UVS & 4.4 & 0.0178 & 0.0001 & 0.145236 & 0.000085 & 0.0806 & 0.0012 & 21.86 & 0.01 & 0.143633 & 12.62 & \\
\hline CH7A & UVS & 4.4 & 0.0052 & 0.0002 & 0.159383 & 0.000572 & 0.0537 & 0.0008 & 50.19 & 0.18 & 0.155703 & 22.08 & 5.28 \\
\hline $\mathrm{CH} 3$ & UVS & 4.5 & 0.0278 & 0.0001 & 0.169787 & 0.000100 & 0.1424 & 0.0021 & 24.78 & 0.02 & 0.167921 & 31.66 & 5.40 \\
\hline $\mathrm{CH} 4$ & UVS & 4.4 & 0.0150 & 0.0001 & 0.162934 & 0.000213 & 0.0984 & 0.0015 & 31.77 & 0.04 & 0.160632 & 25.94 & 5.41 \\
\hline $\mathrm{CH} 1 \mathrm{~B}$ & UVS & 4.4 & & & & & & & & & & & 5.40 \\
\hline $\mathrm{CH} 1 \mathrm{~A}$ & UVS & 4.3 & & & & & & & & & & & 5.47 \\
\hline $\mathrm{CH} 9$ & LVS & 37.0 & 0.0247 & 0.0001 & 0.133402 & 0.000060 & 0.0864 & 0.0013 & 16.88 & 0.01 & 0.123004 & -3.39 & 5.31 \\
\hline CH11 & LVS & 42.6 & 0.0820 & 0.0002 & 0.145955 & 0.000095 & 0.2629 & 0.004 & 15.49 & 0.01 & 0.134960 & 6.03 & 5.45 \\
\hline $\mathrm{CH} 13$ & LVS & 43.6 & 0.0520 & 0.0001 & 0.169542 & 0.000216 & 0.2948 & 0.0044 & 27.44 & 0.04 & 0.149601 & 17.54 & 5.28 \\
\hline CH12 & LVS & 43.0 & 0.0630 & 0.0002 & 0.152965 & 0.000106 & 0.1183 & 0.0018 & 8.93 & 0.01 & 0.146563 & 15.15 & 5.58 \\
\hline
\end{tabular}

\section{Results}

\subsection{Radiometric Ages}

Our new radiometric ages for Christmas Island are consistent with the previous work [10]. The dated LVS samples are of Eocene age and range from 37.0-43.6 Ma (this study; $n=6 ;[10] ; n=3 ;[51]$ ). The dated UVS are of Pliocene age and range from $3.06 \pm 0.28$ to $4.95 \pm 0.12$ to $5.08 \pm 0.60 \mathrm{Ma}$ (all errors are 2 sigma; this study), $4.31 \pm 0.14$ to $4.52 \pm 0.18 \mathrm{Ma}(n=4 ;[10])$ and $4.32 \pm 0.17$ [51].

\subsection{Petrography and Mineral Chemistry}

The rocks of the LVS consists of dykes, lava and hyaloclastite breccia. Petrographically they include olivine + clinopyroxene \pm plagioclase-phyric basalts, basanites, mugearites, and minor trachytes (Table S5). Smith [52] provides detailed petrographic descriptions of LVS rocks. The mafic volcanics contain euhedral phenocrysts and microphenocrysts of olivine (EDS, Mg\# 75.4-89.2; WDS, Mg\# 70.3-89.5; Tables S3 and S4, Figures 2 and 3), clinopyroxene (augite; EDS, Mg\# 76.8-85.5; WDS Mg\# 80.3-85.9, Tables S3 and S4, Figure 2) 
and plagioclase (EDS, An 55-70). The groundmass consists of plagioclase (EDS, An 8-66) and augite microlites (EDS, Mg\# 67-79) which form an intersertal texture with altered glass, ilmenite and titanomagnetite. The olivine + clinopyroxene-phyric basalts also contain groundmass olivine. More evolved volcanic compositions contain microphenocrysts of ilmenite and apatite. Some of the olivine + clinopyroxene-phyric basalts of the LVS are distinctive in containing abundant xenolithic material (e.g., samples 70472, 70469) including ultramafic inclusions $(\sim 10-50 \mathrm{~mm}$ in size) and xenocrysts apparently derived from disrupted xenolithic material. The ultramafic inclusions are of both cumulate (websterite and wehrlite) and mantle (lherzolite and harzburgite) origin. Cumulates contain olivine (Fo78-87), augite (Mg\# 80-85), orthopyroxene (Mg\#83-87), Cr-spinel (Cr\# 50) and titanomagnetite. The mantle-derived material consists of olivine (Fo91-92), clinopyroxene (endiopside, Mg\# 93), orthopyroxene (Mg\# 91) and Al-spinel (Falloon unpublished data). The $\mathrm{Ni}$ and $\mathrm{CaO}$ abundances of the olivine phenocrysts (Figure 3 ) are typical for OIB plume-related lava [53].

The rocks of the UVS contain euhedral phenocrysts and microphenocrysts of olivine (EDS, Mg\# 85.0-89.5; WDS, 85.6-90.4, Tables S3 and S4, Figures 2 and 3) and clinopyroxene (diopside; EDS Mg\# 73-86; WDS Mg\# 71-86, Tables S3 and S4, Figure 2), set in a groundmass consisting of turbid glass with diopside microlites (Mg\# 67-84) and titanomagnetite. Crspinel occurs both as inclusions in olivine phenocrysts and as microphenocrysts (Cr\# 61-64). Petrographically these rocks are limburgites. The Ni abundances of the olivine phenocrysts (Figure 3) are typical of MORB-related lava [53]

\section{Lower Volcanic Series}
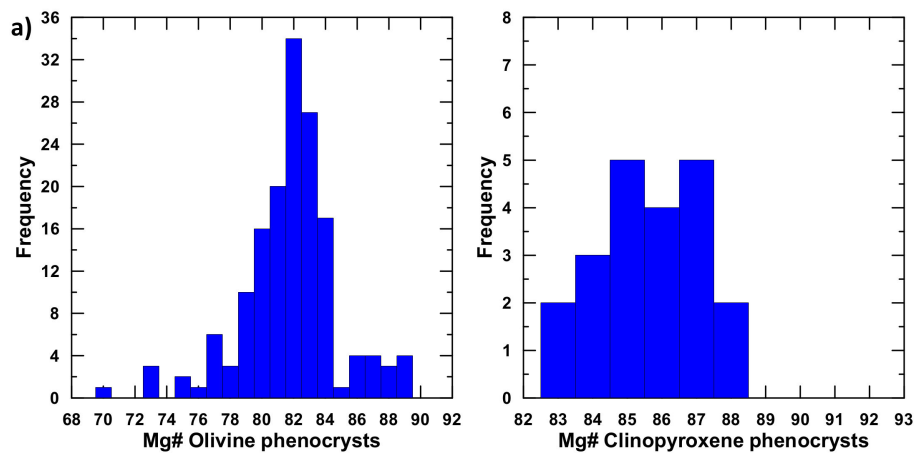

Upper Volcanic Series
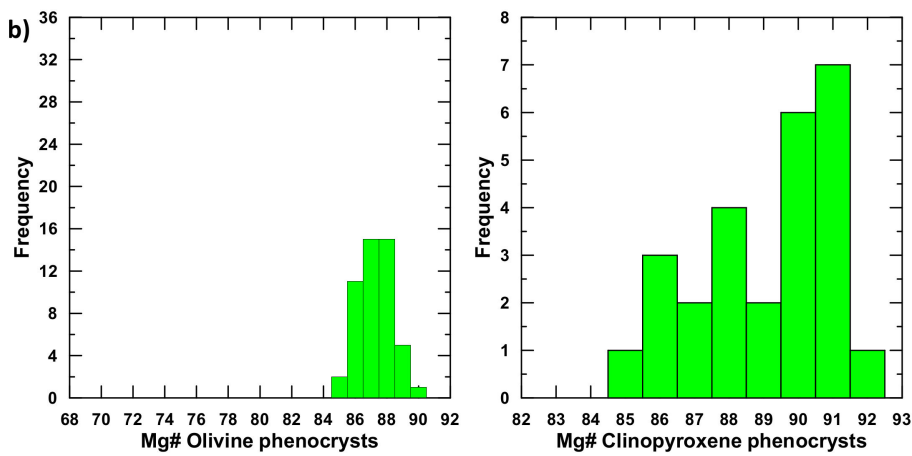

Figure 2. Histograms of olivine and clinopyroxene phenocryst compositions (Mg\#) for primitive lava of Christmas Island; (a) Lower Volcanic Series (LVS) and (b) Upper Volcanic Series (UVS). Mineral data from Table S4. 


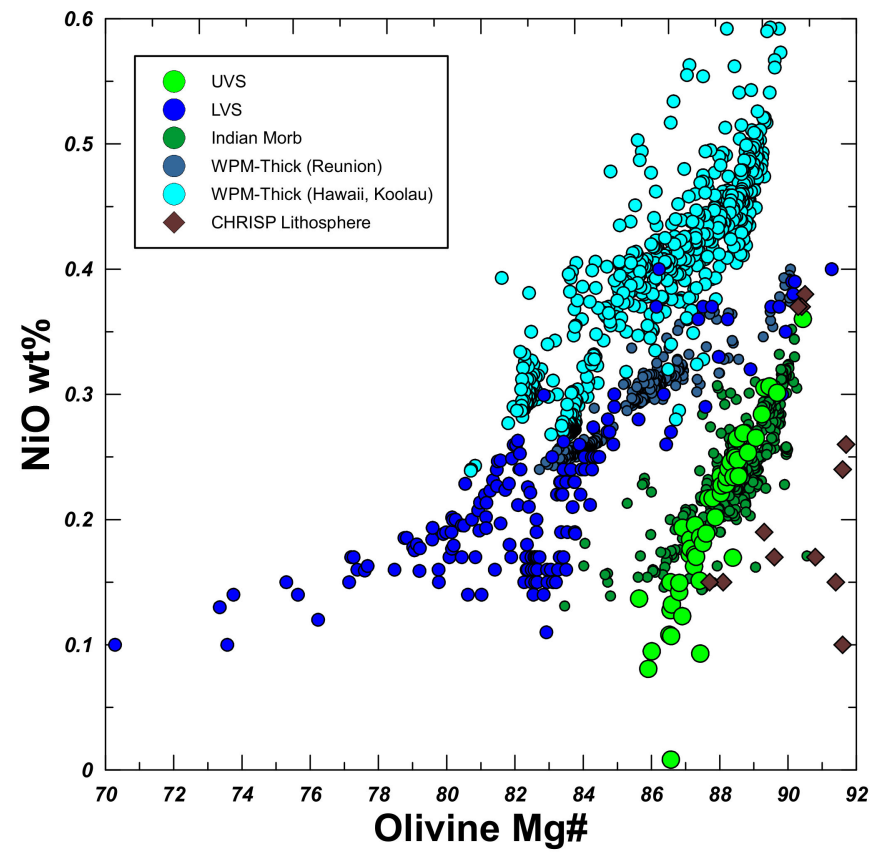

(a)

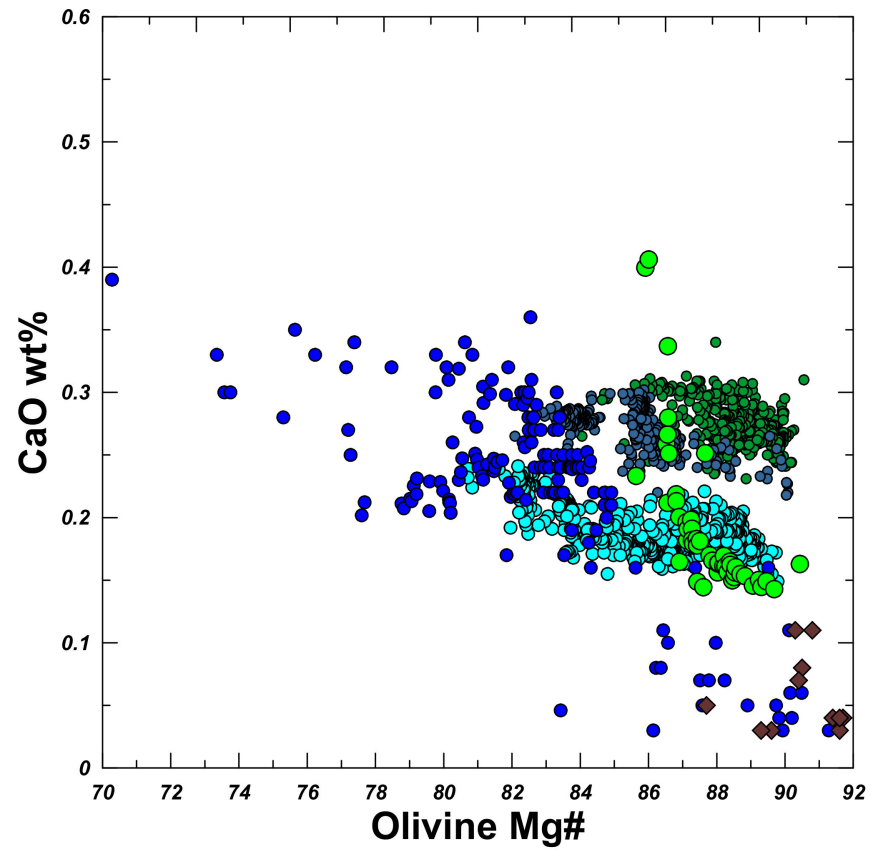

(b)

Figure 3. Olivine (a) $\mathrm{Ni}(\mathrm{ppm})$ and (b) $\mathrm{CaO}(\mathrm{wt} \%$ ) abundances versus $\mathrm{Mg \#}$ for the Christmas Island lava series (Table S4) compared to Indian MORB, Reunion and Hawaiian lavas. WPM-thick = within plate magmas erupted through thick $(>70 \mathrm{~km})$ lithosphere; UVS $=$ Christmas Island upper volcanic series; LVS = Christmas Island lower volcanic series. Olivine data from [53] and Falloon (unpublished). High Mg\# olivines with low $(\sim<0.12 \mathrm{wt} \%) \mathrm{CaO}$ abundances are inferred to be xenocrystal material from the oceanic lithosphere (CHRISP Lithosphere, $(\mathbf{b})$ ).

Altered volcanic rocks from "1341 m" and "1763 m" seamounts to the southwest of Christmas Island (Figures 1 and S6, Table S1) have phenocryst assemblages like rocks of the LVS of Christmas Island. The rocks contain pseudomorphs after olivine phenocrysts, now completely replaced by secondary minerals, together with part-resorbed plagioclase, and clinopyroxene phenocrysts set in an altered cryptocrystalline groundmass with plagioclase microlites.

\subsection{Whole-Rock Geochemistry}

Loss on ignition (LOI) values vary significantly for both the LVS and UVS (Figure 4), consistent with petrographic evidence for alteration. Out of 33 LVS samples, six have elevated LOI of 3.0-5.5 wt.\%. Out of 16 UVS samples, four have LOI between 3.0-3.9 wt.\%. However, this alteration has not significantly changed the primary geochemical characteristics of the lavas. There are no correlations between LOI with age of sample or any geochemical element or index (Figure 4). Furthermore, mobile incompatible oxides/elements such as $\mathrm{K}_{2} \mathrm{O}$ correlate positively with immobile incompatible elements excluding submarine samples for the older LVS series, e.g., $\mathrm{TiO}_{2}\left(\mathrm{r}^{2}=0.90\right.$, excluding one outlier), $\mathrm{Zr}\left(\mathrm{r}^{2}=0.95\right.$, combining XRF and ICP-MS data) and $\mathrm{Nb}\left(\mathrm{r}^{2}=0.92, \mathrm{XRF}+\mathrm{ICP}-\mathrm{MS}\right.$ data), La $\left(\mathrm{r}^{2}=0.94\right.$, ICP-MS data only), Th $\left(\mathrm{r}^{2}=0.95\right.$, ICP-MS data), Ta $\left(\mathrm{r}^{2}=0.90\right.$, ICP-MS data) and $\mathrm{Hf}\left(\mathrm{r}^{2}=0.96\right.$, ICP-MS data). Also, mobile oxides/elements correlate well with each other, e.g., $\mathrm{K}_{2} \mathrm{O}$ vs. $\mathrm{Na}_{2} \mathrm{O}\left(\mathrm{r}^{2}=0.79\right), \mathrm{U}\left(\mathrm{r}^{2}=0.90\right.$, ICP-MS data), $\mathrm{Rb}\left(\mathrm{r}^{2}=0.97, \mathrm{XRF}+\mathrm{ICP}-\mathrm{MS}\right.$ data). Thus, we are confident in using the geochemistry of the lava for rock classification as well as in comparing the major and trace-element data with the lava compositions from other localities. In Figure S7 we demonstrate excellent correlations for trace element abundances determined by different (XRF, ICP-MS and INAA) techniques. We are therefore confident 
that the trace element abundances reported in this study can be used to develop potential petrogenetic models for Christmas Island magma genesis.
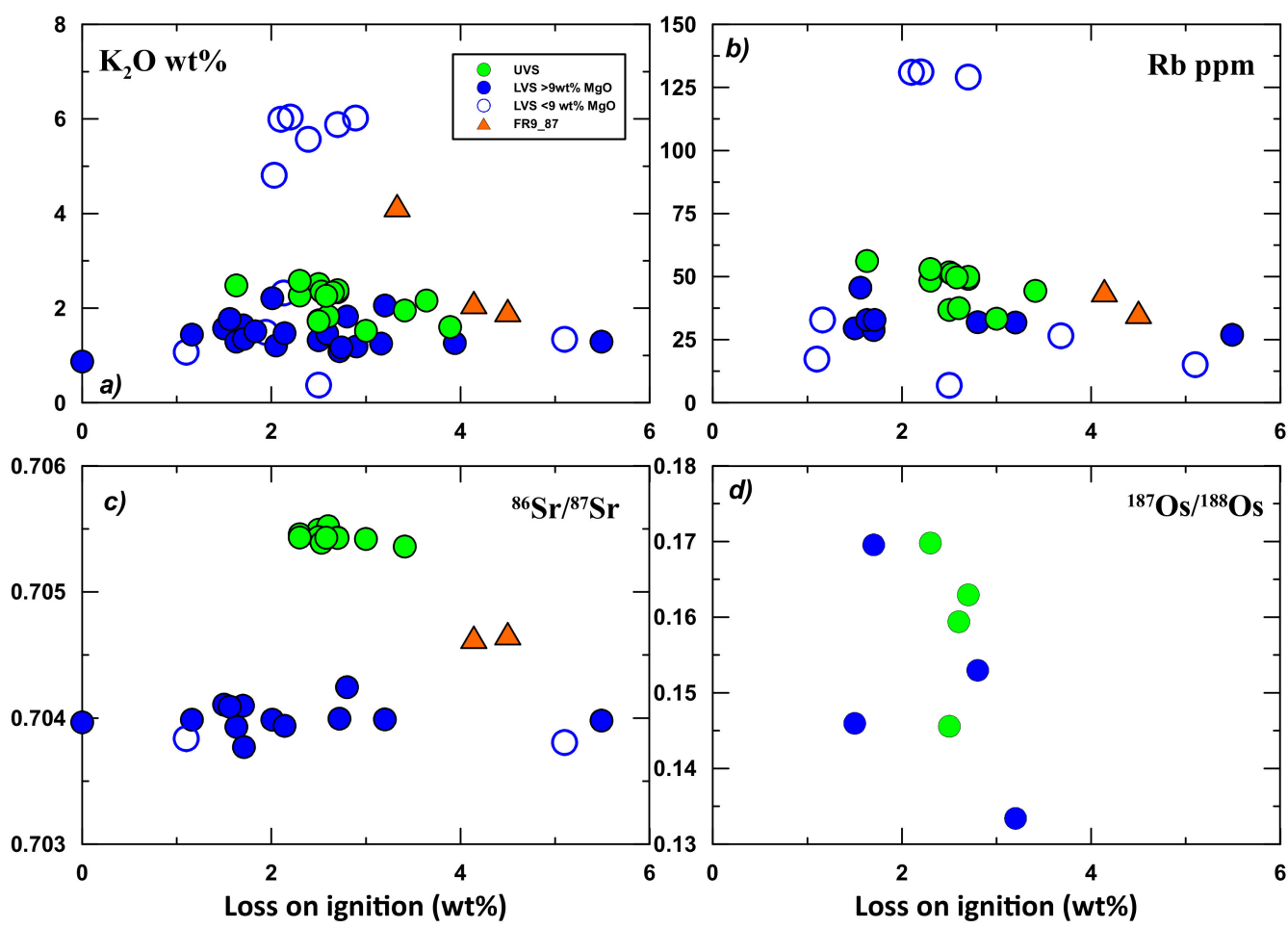

Figure 4. Loss on Ignition (LOI) values for Christmas Island high $\mathrm{MgO}$ lava ( $>9 \mathrm{wt} \%$ ) and low $\mathrm{MgO}$ lava $(<9 \mathrm{wt} \%$ ) (Table S5) and dredged lava from the VMP by the RV Franklin during voyage FR9_87 (Table S5) versus (a) $\mathrm{K}_{2} \mathrm{O}$ wt \%; (b) $\mathrm{Rb} \mathrm{ppm}$; (c) ${ }^{87} \mathrm{Sr} /{ }^{86} \mathrm{Sr}$ values (Table 2, [10,43]), (d) ${ }^{187} \mathrm{Os} /{ }^{188} \mathrm{Os}$ values (Table 3).

In the TAS (total-alkalis vs. silica) classification plot (Figure 5; [54]) whole rock (Table S5) and scans of unaltered glassy groundmass (Table S3) of the Christmas Island series lava are clearly distinct. The LVS forms a sodic $\left(\mathrm{Na}_{2} \mathrm{O} / \mathrm{K}_{2} \mathrm{O} \sim>2\right)$ alkaline series (Mg\# 71-10) whereas the UVS forms a primitive slightly potassic $\left(\mathrm{Na}_{2} \mathrm{O} / \mathrm{K}_{2} \mathrm{O} \sim<0.9\right)$ alkaline series (Mg\# 72-63). Both series appear to form coherent liquid lines of descent based on the variation of compatible to incompatible trace elements (e.g., Ni vs. Zr; Figure 6) suggesting a limited range in parental magma compositions for each lava series.

The more primitive rocks from both lava series show a restricted range in REE (Figure 7a) and the two series can be clearly distinguished-with the UVS being more enriched in LREE and have relatively higher $(\mathrm{La} / \mathrm{Yb})_{\mathrm{N}}$ values compared to the LVS (22-29 vs. 11-20). This results in crossing REE patterns (Figure 7a), which can be explained by differences in petrogenetic conditions and mantle sources for the two volcanic series (see discussion in Section 4 below). In contrast, rocks with $<9 \mathrm{wt} \% \mathrm{MgO}$ have much more variable patterns and range in abundances (Figure $7 \mathrm{~b}$ ) - this could be due to differences in parental magmas, crystal fractionation and potentially assimilation of depleted mantle lithosphere or crustal components during magma evolution. As we wish to explore the nature of primitive magmatic components in order to constrain the petrogenesis of the two volcanic series on Christmas Island, we restrict our discussion to rocks with $\mathrm{MgO}$ values $>9 \mathrm{wt} \% \mathrm{MgO}$. 


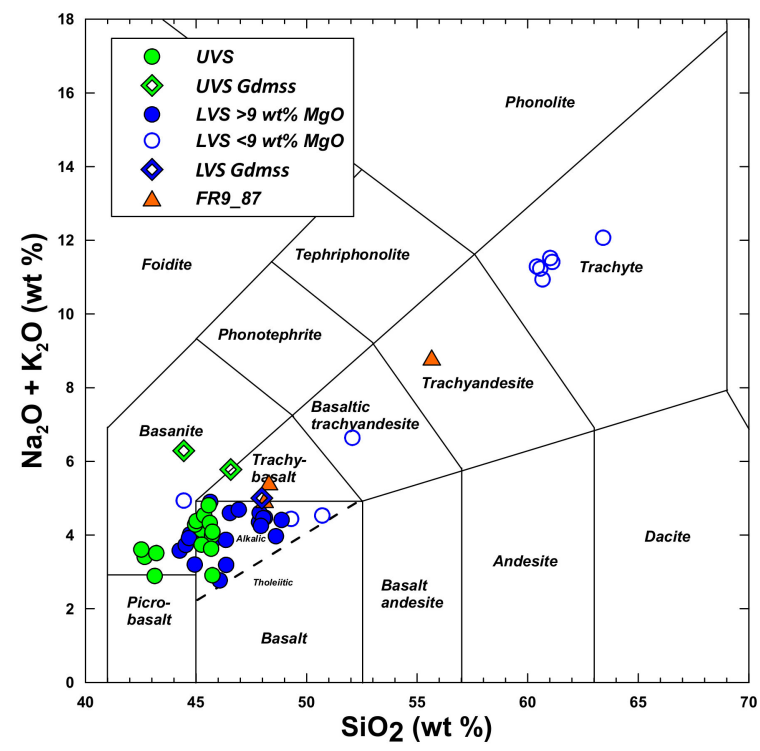

Figure 5. Christmas Island lava plotted in the total alkali $\left(\mathrm{Na}_{2} \mathrm{O}+\mathrm{K}_{2} \mathrm{O}\right)$ vs. silica $\left(\mathrm{SiO}_{2}\right)(\mathrm{TAS})$ classification for igneous volcanic rocks [54]. Data from Tables S3 and S5.

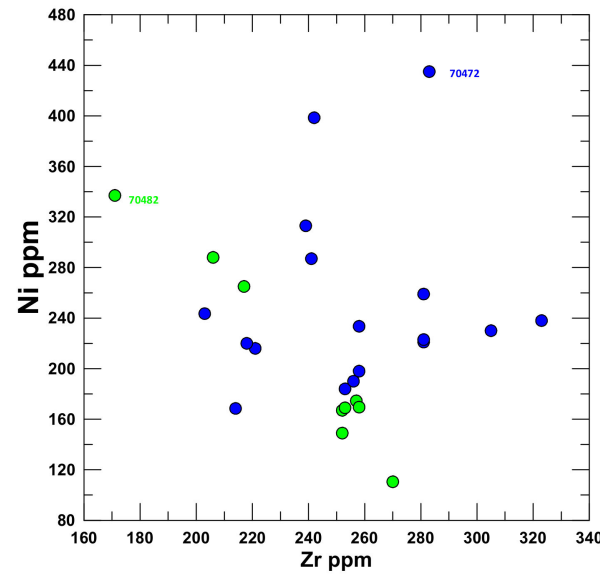

(a)

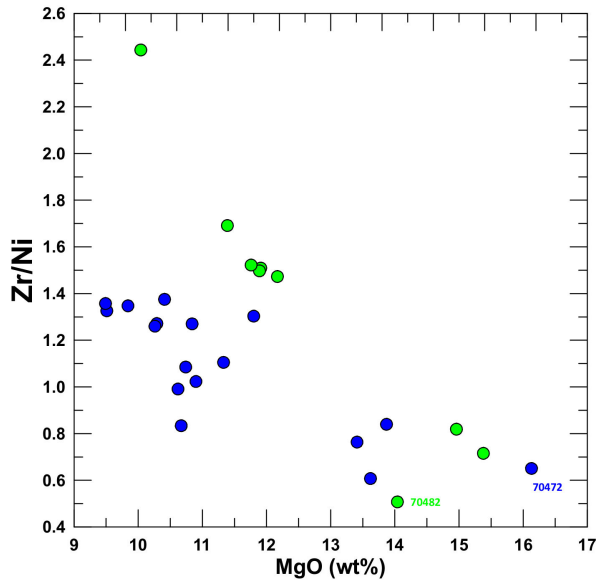

(b)

Figure 6. The Ni ppm (a) and $\mathrm{Zr} / \mathrm{Ni}$ values (b) versus $\mathrm{Zr}$ ppm for the Christmas Island lava series. Outliers 70472 has accumulated olivine and xenolithic material whereas 70482 was recovered by dredging during FR9_87 and most likely represents a slightly different parental magma composition of the UVS.

In Figures 8 and 9, the major and trace element abundances of the Christmas Island lava series are plotted against their $\mathrm{MgO}$ contents. The two suites can be clearly distinguished on nearly all of the plots, in particular the UVS compared to the LVS have, in general, lower $\mathrm{TiO}_{2}, \mathrm{FeO}^{\mathrm{T}}, \mathrm{Na}_{2} \mathrm{O}, \mathrm{Nb}, \mathrm{Y}, \mathrm{Ni}$ and higher $\mathrm{CaO}, \mathrm{K}_{2} \mathrm{O}, \mathrm{Rb}, \mathrm{Ba}, \mathrm{La}, \mathrm{Sr}$ abundances (Figures 8 and 9). The primitive mantle normalised abundance patterns (NAPs) of the Christmas Island volcanic series are presented in Figure 10. The NAPs of the UVS are all very similar (Figure 10a) -indicating a limited range of parental compositions. In particular, the NAPs for the UVS all show prominent enrichment anomalies in $\mathrm{Ba}$ and $\mathrm{Pb}$. In contrast to the UVS, the NAPs of LVS show more variability (Figure 10b), suggesting a range of parental magmas, they all in general show the same overall relative enrichment in $\mathrm{Nb}$ relative to $\mathrm{U}$ and $\mathrm{K}$ and a depletion in $\mathrm{Pb}$ relative to $\mathrm{Ce}$. 


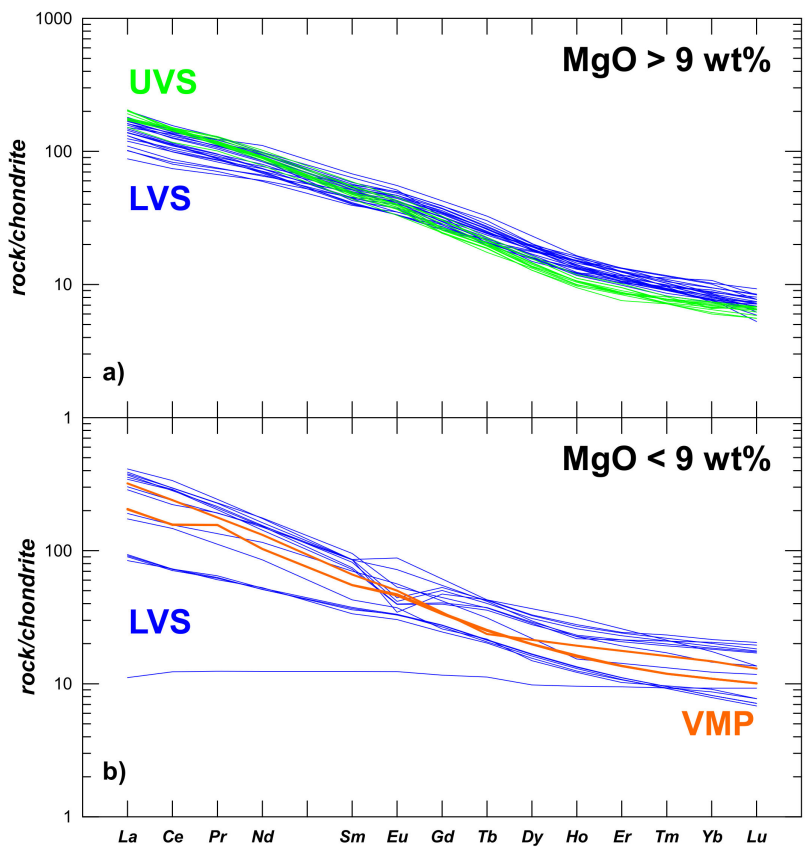

Figure 7. Chondrite normalized REE patterns for the Christmas Island lava series. (a) Lava with $\mathrm{MgO}$ contents $>9 \mathrm{wt} \% \mathrm{MgO}$ and in (b) lava with $<9 \mathrm{wt} \% \mathrm{MgO}$, also plotted in (b) are the lava from the VMP dredged by the RV Franklin during voyage FR9_87.
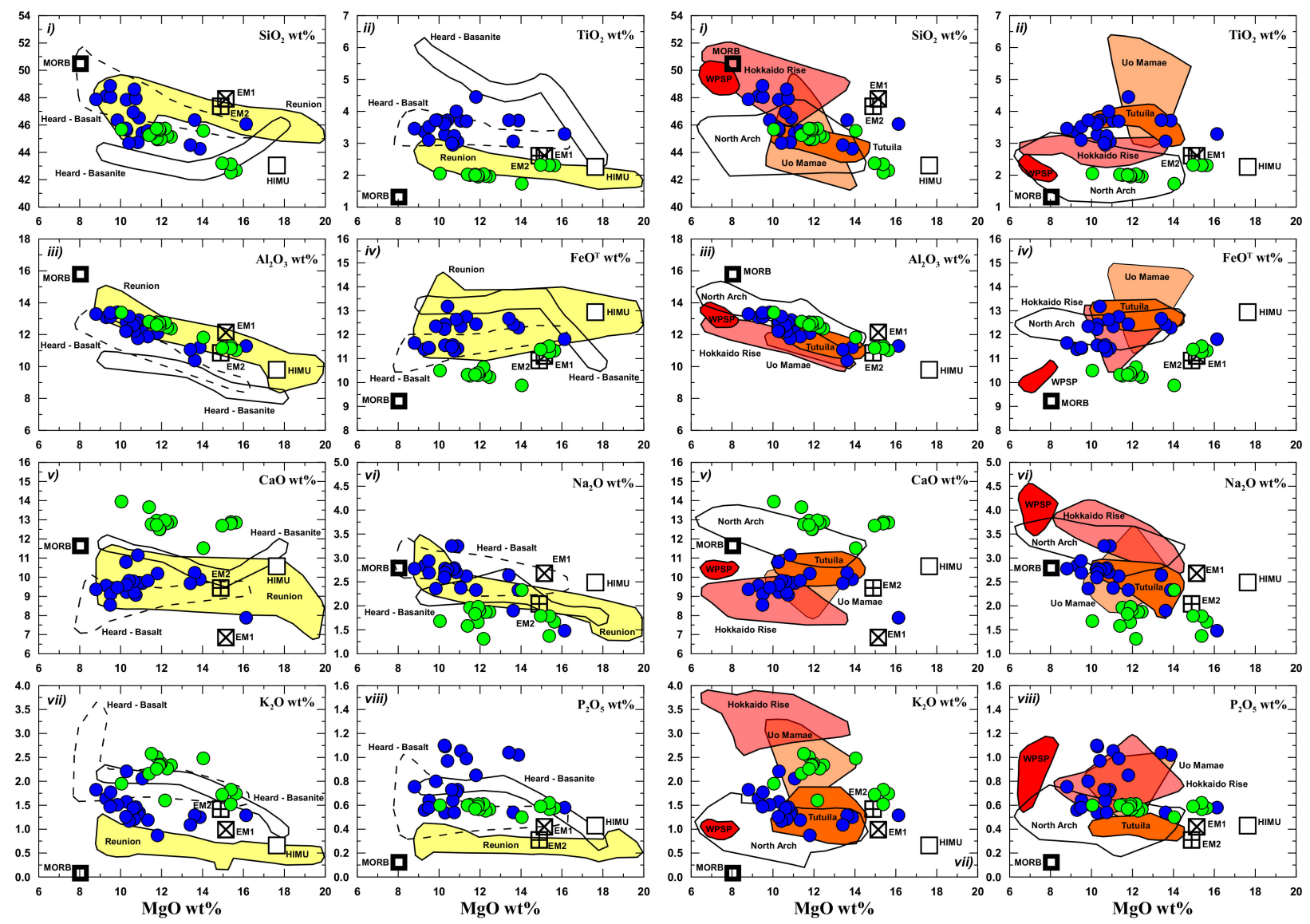

(a)

(b)

Figure 8. (a) Major elements ( $w t \%)$ versus $\mathrm{MgO}(w t \%)$ of Christmas Island lava series (LVS—blue 
circles; UVS-green circles) compared to the Indian Ocean plumes Reunion and Kerguelen. Symbols, fields and data sources as follows: Bold square-average $(n=147)$ Indian N-MORB $\left((\mathrm{La} / \mathrm{Sm})_{\mathrm{N}}<1.0\right.$; [55]); DMM (depleted morb mantle), HIMU (high- $\mu$ mantle), EM1 (enriched mantle 1), EM2 (enriched mantle 2) parental magmas [56]; Kerguelen (Heard Island basaltic and basanite series, >9 wt\% MgO; [57]); Reunion (yellow field, Piton de la Fournaise, lava 9-20 wt\% MgO; [58]). (b) Major elements ( $\mathrm{wt} \%$ ) versus $\mathrm{MgO}(\mathrm{wt} \%)$ of Christmas Island lava series compared to petitspot lava and lava associated with lithospheric flexure. Symbols as for (a), and the following: Hokkaido Rise (light red field; [27]); North Arch volcanic field [59]; Uo Mamae seamount (light orange field; [60-62]); Tutuila Island (orange field; [22]); Western Pacific Seamount Province (red field, WPSP; [63]).
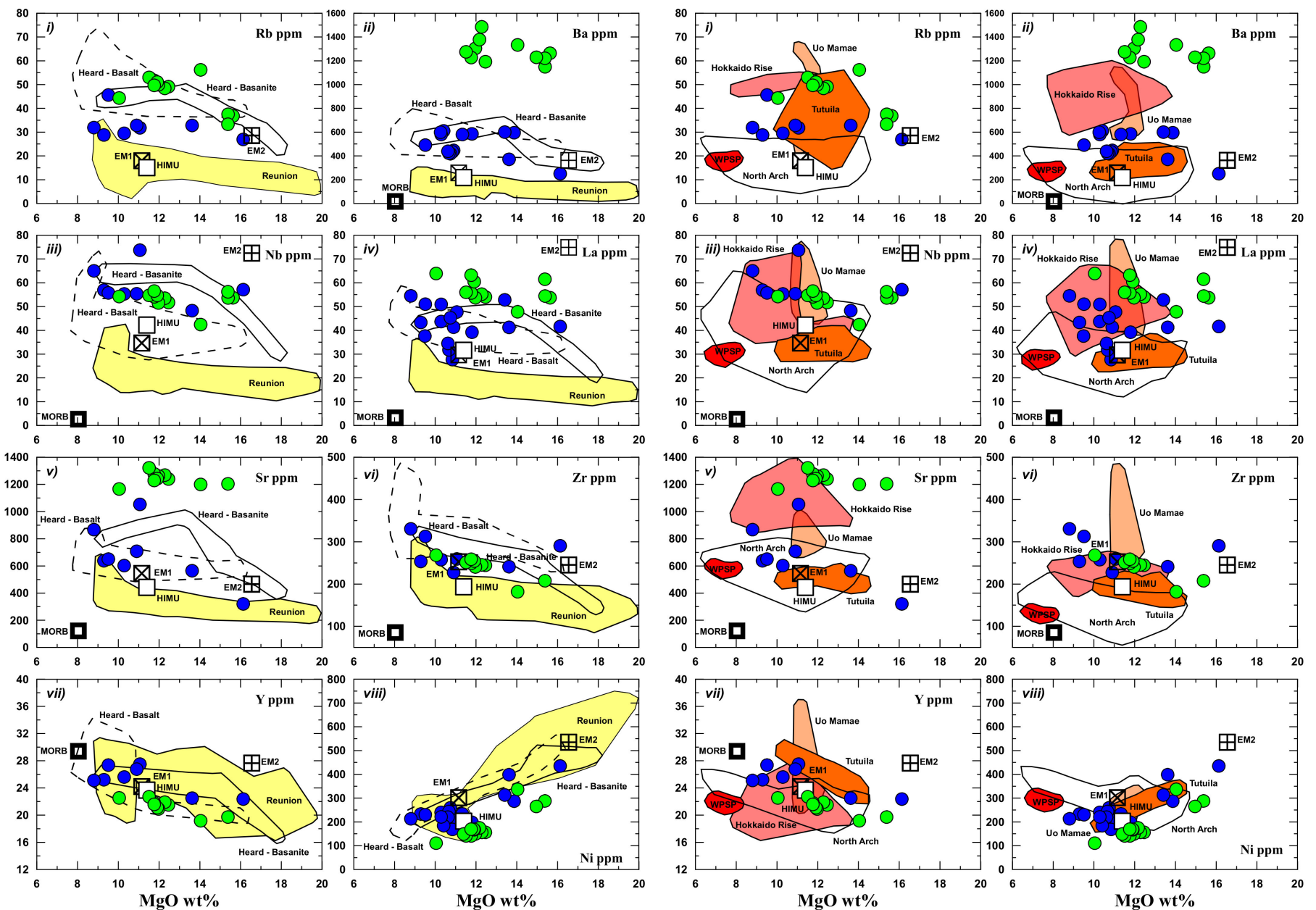

(a)

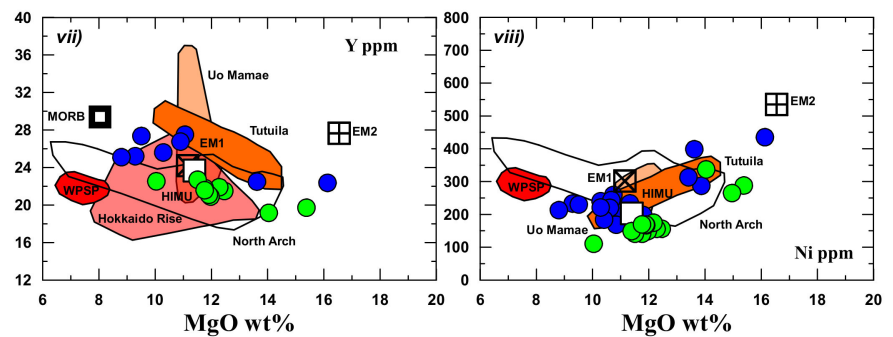

(b)

Figure 9. Trace element (ppm) abundances versus $\mathrm{MgO}(\mathrm{wt} \%$ ) of Christmas Island lava series compared to (a) Indian Ocean plumes Reunion and Kerguelen and (b) petit-spot lava and lava associated with lithospheric flexure. Symbols, fields and data sources as for Figure 8, except for the following: HIMU—average $(n=14)>9 \mathrm{wt} \% \mathrm{MgO}$ lava from Mangaia Island [64]; EM1—average $(n=11)>9 \mathrm{wt} \% \mathrm{MgO}$ lava from Pitcairn Island and adjacent seamounts [65,66]; EMII-average $(n=6)>9 \mathrm{wt} \% \mathrm{MgO}$ lava from Savaii Island, Samoa [67]. 


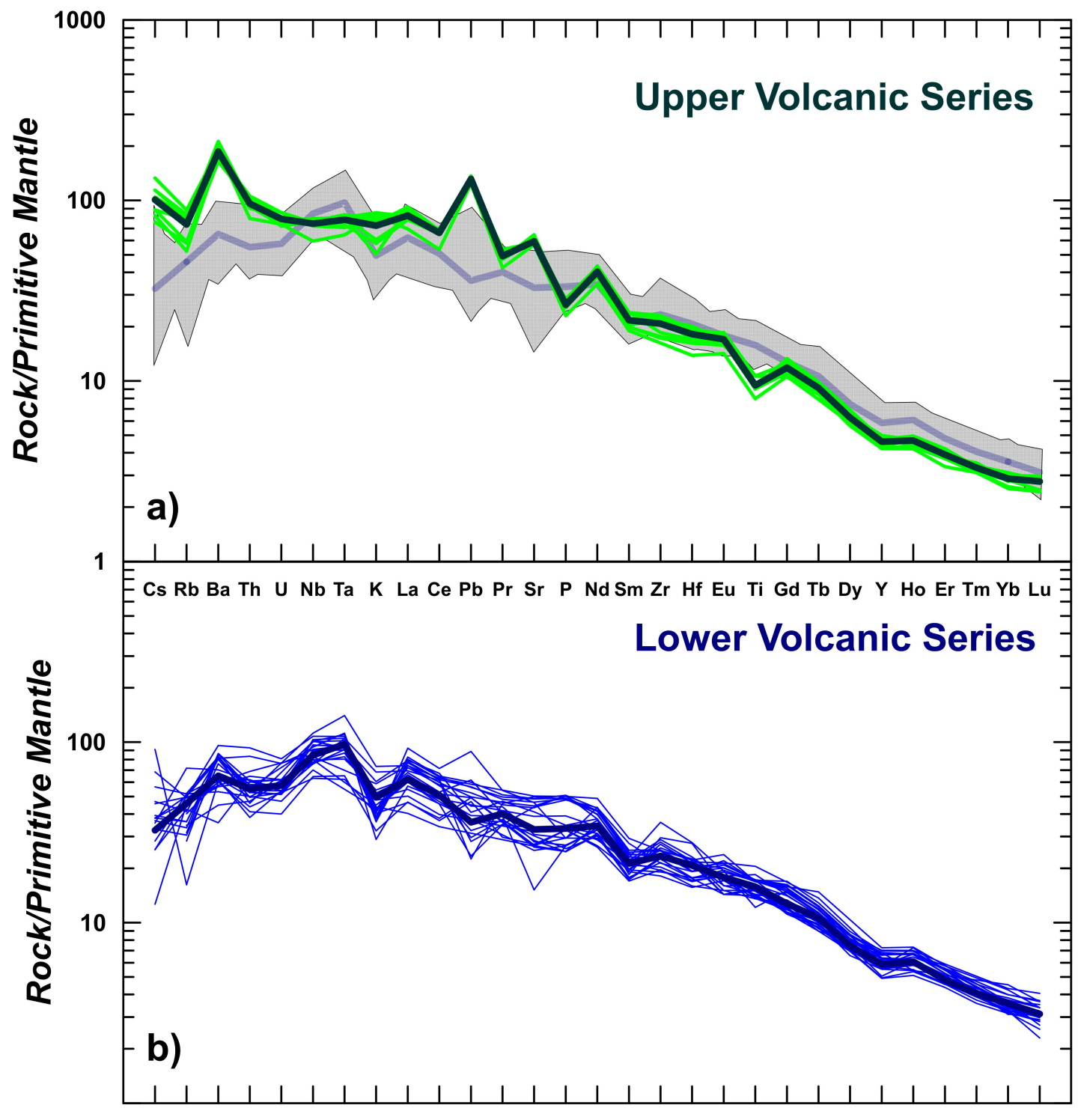

Cs Rb Ba Th U Nb Ta K La Ce Pb Pr Sr P NdSm Zr Hf Eu Ti Gd Tb Dy Y Ho Er Tm Yb Lu

Figure 10. Primitive mantle normalized trace element abundance patterns for Christmas Island lava series; (a) Upper volcanic series— thin green lines, lava with $>9 \mathrm{wt} \% \mathrm{MgO}$, thick dark green lineaverage; pale blue thick line is the average pattern for LVS lava with $>9 \mathrm{wt} \% \mathrm{MgO}$ for comparison; gray field encompasses the range in patterns for the LVS lava in panel b; (b) Lower volcanic seriesthin blue lines, lava with $>9 \mathrm{wt} \% \mathrm{MgO}$, thick dark blue line-average. Primitive mantle normalizing values from [68].

The dredged volcanic rocks from two seamounts of the WMP (FR9_87; Table S5) all have high LOI, reflecting seafloor alteration. However, despite this alteration, they display a high degree of geochemical coherence (Figures 4 and 7). In terms of major element geochemistry, the dredged volcanics have relatively low $\mathrm{MgO}$ abundances $(\sim<4.5 \mathrm{wt} \%)$ and are most similar to the evolved lava of the Christmas Island LVS, which is consistent with their petrographic affinities.

\subsection{Sr-Nd-Pb Isotopic Geochemistry}

The new isotopic data presented here (Table 2) is completely consistent with the isotopic values obtained previously by $[10,43]$. The excellent coherence of leached and unleached samples on the various isotope plots (e.g., Figure 11) suggests that there is no significant alteration component which is affecting the isotope data. The new isotope data 
confirm that the LVS ( $n=21$, new and published data) and UVS ( $n=11$, new and published data) have distinct ${ }^{87} \mathrm{Sr} /{ }^{86} \mathrm{Sr},{ }^{143} \mathrm{Nd} /{ }^{144} \mathrm{Nd},{ }^{206} \mathrm{~Pb} /{ }^{204} \mathrm{~Pb},{ }^{207} \mathrm{~Pb} /{ }^{204} \mathrm{~Pb}$ and ${ }^{208} \mathrm{~Pb} /{ }^{204} \mathrm{~Pb}$ isotope ratios, in contrast [69] who obtained a similar isotopic composition for their single Pliocene (UVS) sample to the LVS, although the LVS compositions match those of the new and data published elsewhere $[10,43]$.

\begin{tabular}{|llllll|}
\hline & UVS - this study & $\square$ & LVS - [43] & $\bigcirc$ & Kerguelen \\
$\diamond$ & UVS - [10] & $\triangle$ & FR9_87 & $\bigcirc$ & Reunion \\
$\bigcirc$ & LVS - this study & $\bullet$ & Japan Trench & $\mathbf{\square}$ & r-SCLM \\
LVS-[10] & $\bigcirc$ & Uo Mamae & $\square$ & Indian N-MORB \\
\hline
\end{tabular}

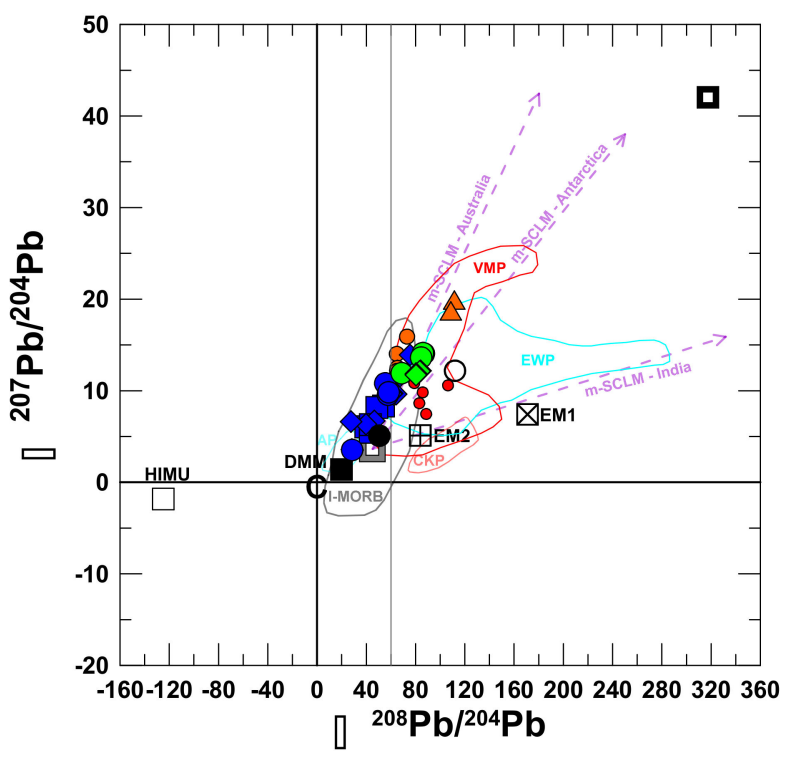

(a)

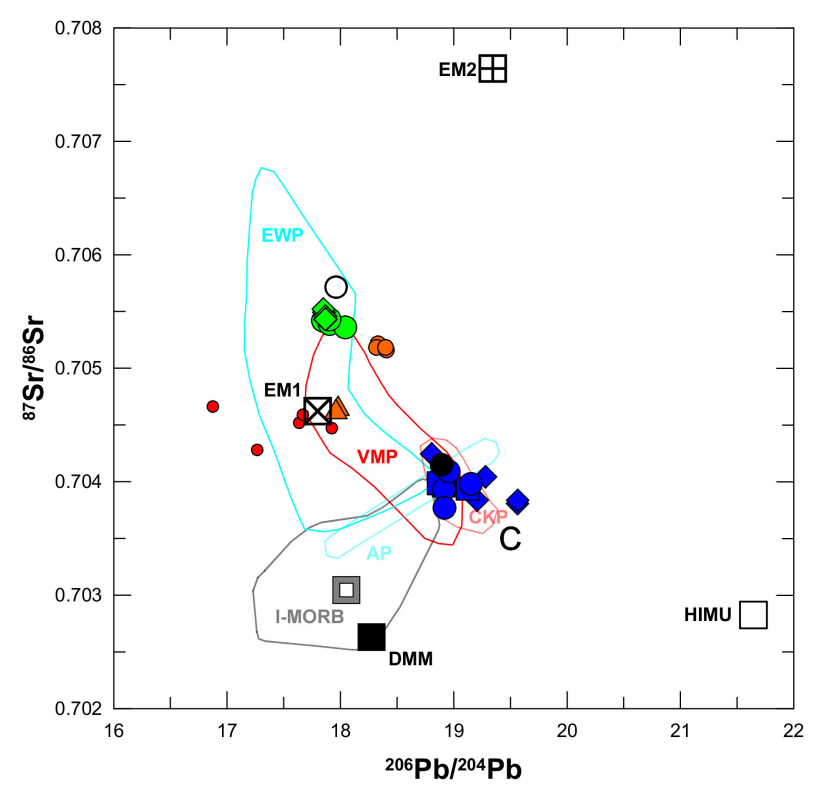

(b)

Figure 11. (a) $\Delta^{208} \mathrm{~Pb} /{ }^{204} \mathrm{~Pb}$ versus $\Delta^{207} \mathrm{~Pb} /{ }^{204} \mathrm{~Pb}[36]$ and (b) ${ }^{87} \mathrm{Sr} /{ }^{86} \mathrm{Sr}$ versus ${ }^{206} \mathrm{~Pb} /{ }^{204} \mathrm{~Pb}$ for Christmas Island lava series (Table 2; $[10,43]$ ). Delta $(\Delta)$ values measure the vertical deviation in ${ }^{207} \mathrm{~Pb} /{ }^{204} \mathrm{~Pb}$ or ${ }^{208} \mathrm{~Pb} /{ }^{204} \mathrm{~Pb}$ from a northern hemisphere reference line (NHRL, solid vertical and horizontal lines at 0 in (a)) as defined by [36]. Symbols, lines and data fields as follows: Grey vertical line at $\Delta^{208} \mathrm{~Pb} /{ }^{204} \mathrm{~Pb}=60$ is after [43] who define DUPAL hotspot lava with $\Delta^{208} \mathrm{~Pb} / \Delta^{204} \mathrm{~Pb}>60$, with ${ }^{87} \mathrm{Sr} /{ }^{86} \mathrm{Sr}>0.705$; Indian $\mathrm{N}-\mathrm{MORB}$ is the average glass $(n=157)$ where all $\mathrm{Sr}-\mathrm{Nd}-\mathrm{Pb}$ isotopes have been analyzed on the same glass sample (grey field, I-MORB (Indian morb) delineates the range of glasses; [70]); Purple dotted line labelled ' $m$-SCLM-India' (metasomatized subcontinental lithospheric mantle) trends towards the average $(n=7)$ Krishna Lamproite $\left(\Delta^{208} \mathrm{~Pb} / \Delta^{204} \mathrm{~Pb} \sim 545 ; \Delta^{207} \mathrm{~Pb} / \Delta^{204} \mathrm{~Pb} \sim 25\right.$; [71]); Purple dotted line labelled 'm-SCLM-Antarctica' trends towards inferred compositions of Antarctica m-SCLM constrained by the average $(n=26)$ composition of Gaussberg olivine lamproites [72]; Purple dotted line labelled 'm-SCLM-Australia' trends towards inferred compositions of Australian m-SCLM constrained by the average $(n=6)$ composition of Western Australian olivine lamproites ( $>9 \mathrm{wt} \% \mathrm{MgO}$; [73]); r-SCLM (refractory subcontinental lithospheric mantle; [74]); CHRISP fields [10] as follows: CKP-Cocos/Keeling Province; EWP_Eastern Wharton Province; VMP — Vening-Meinesz Province; AP_Argo Province; Japan Trench [75]; Uo Mamae [61,62]; Reunion (average $n=70$ analyses from Piton de la Fournaise; [58]); Kerguelen (Heard Island, average for the Big Ben lava series; [57]); DMM- ${ }^{206} \mathrm{~Pb} /{ }^{204} \mathrm{~Pb}$ and ${ }^{207} \mathrm{~Pb} /{ }^{204} \mathrm{~Pb}$ values from [76]) and ${ }^{208} \mathrm{~Pb} /{ }^{204} \mathrm{~Pb}$ values from [77]; HIMU-average $(n=14)>9 \mathrm{wt} \% \mathrm{MgO}$ lava from Mangaia Island [64]; EM1—average $(n=11)>9 \mathrm{wt} \% \mathrm{MgO}$ lava from Pitcairn Island and adjacent seamounts [65,66]; EMII-average $(n=6)>9 \mathrm{wt} \% \mathrm{MgO}$ lava from Savaii Island, Samoa [67]; Component- “C" ${ }^{\prime}[78]$. 
The $\Delta^{207} \mathrm{~Pb} /{ }^{204} \mathrm{~Pb}(\Delta 7 / 4 \mathrm{~Pb})$ and $\Delta^{208} \mathrm{~Pb} /{ }^{204} \mathrm{~Pb}(\Delta 8 / 4 \mathrm{~Pb})$ values of the seamount lava dredged during FR9_87 are isotopically distinct from the Christmas Island lava series and plot (Figure 11a) within the field defined by seamounts of the VMP [10]. The Christmas Island lava series almost encompass the entire range of ${ }^{87} \mathrm{Sr} /{ }^{86} \mathrm{Sr}$ and ${ }^{206} \mathrm{~Pb} /{ }^{204} \mathrm{~Pb}$ values (Figure 11b) of the VMP. On all isotope correlation diagrams the LVS could potentially serve as the geochemical end member with FOZO (focus zone)-like composition (radiogenic $\mathrm{Pb}$ ) for the VMP of CHRISP. The UVS lava however have lower ${ }^{207} \mathrm{~Pb} /{ }^{204} \mathrm{~Pb}$ and higher ${ }^{176} \mathrm{Hf} /{ }^{177} \mathrm{Hf}$ isotope ratios to serve as the enriched end member with low ${ }^{206} \mathrm{~Pb} /{ }^{204} \mathrm{~Pb}$ isotope ratios (Figure S8; [10]).

\subsection{Osmium Isotopes}

In general, the LVS has slightly higher Os abundances (range 25-64 ppt, Table 3) compared to UVS (range 15-33 ppt, Table 3, Figure 12). Although the Os abundances overlap, they can clearly be distinguished when plotted against $\mathrm{MgO}$ wt\% (Figure 12). Both lava series have similar Os ppt abundances to a range of oceanic and continental intraplate magmatic suites (Figure 12). However, the UVS Os abundances all fall below the recommended value of $50 \mathrm{ppt}$ for uncontaminated lava from the Canary and Madeira Islands $[79,80]$.

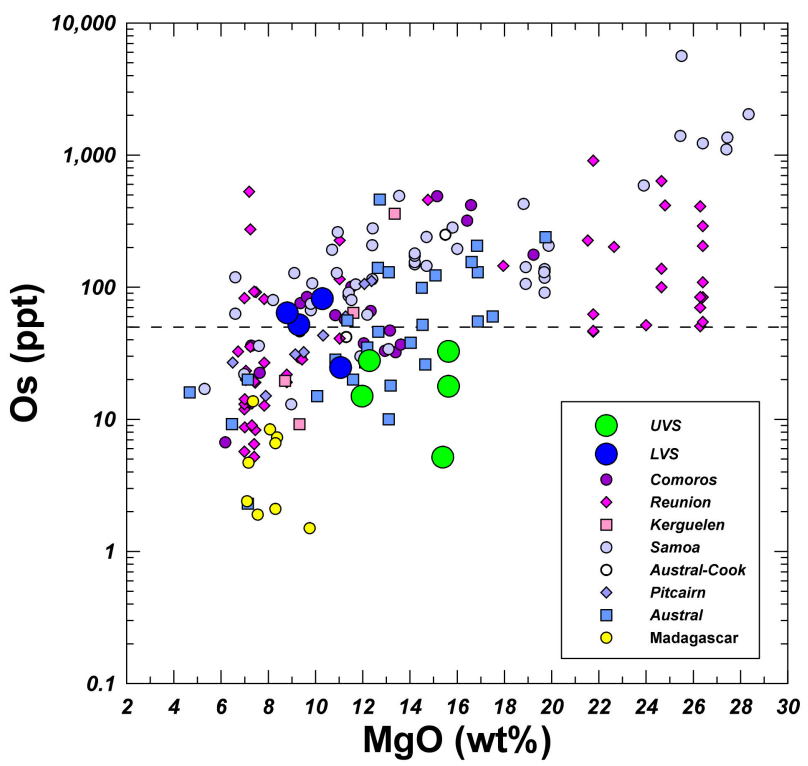

Figure 12. Os (ppt) versus $\mathrm{MgO}(\mathrm{wt} \%)$ for the Christmas Island lava series compared to other intraplate lava suites. Data sources as follows: Comoros [81]; Reunion [82-84]; Kerguelen [85]; Samoa [86,87]; Pitcairn [66]; Austral [82,88]; Austral-Cook [89]; Madagascar [74]. The horizontal dotted line at Os 50 ppt is the proposed cut off filter [79] to eliminate crustally contaminated lavas.

The LVS lava have overall lower ${ }^{187} \mathrm{Os} /{ }^{188} \mathrm{Os}_{\mathrm{i} \text { (initial) }}$ isotopic values (0.123-0.150; $\gamma \mathrm{Os}_{\mathrm{i}}=-3.4$ to 17.5; Table 3) than the UVS lava (0.144-0.167; $\gamma \mathrm{Os}_{\mathrm{i}}=12.6$ to 31.7; Table 3). In Figure $13{ }^{187} \mathrm{Os} /{ }^{188}$ Os isotopic values are plotted against Os abundances (ppt) at two different scales. In Figure 13a, the Christmas Island lava series plot in the bottom left corner-where we expect to see uncontaminated mantle derived lava $\left({ }^{187} \mathrm{Os} /{ }^{188} \mathrm{Os}\right.$ values of $\leq 0.15 ;$ [90]). In Figure $13 \mathrm{~b}$ the data falling inside the shaded rectangle in Figure 13a is shown to illustrate in more detail the relationship of the Christmas Island lava series to potential crustal and lithospheric contamination. As discussed by [91] a significant difficulty in the interpretation of Os isotopic data is the potential problem of (1) crustal contamination or alteration by seawater, especially in evolved magmas with relatively lower Os abundances which can produce anomalously high Os isotopic values at low Os ppt and (2) contamination by the lithospheric mantle either via melt-rock reaction or the incorporation of xenolithic material (especially olivine) resulting in very high Os abun- 
dances and low (subchondritic) Os isotopic values [92]. The LVS sample CH9 therefore is of interest as it has initial subchondritic Os isotopic values at relatively low Os abundances (Table 3).

One potential solution to this problem is to apply a filter, for example [79] recommend that only Os isotopic values for lava with greater than $~ 50$ ppt should be used to define uncontaminated magmatic values. Applying such a filter to the Christmas Island lava series would eliminate the majority of the data set (Figure 12). Although suites with low Os and high ${ }^{187}$ Os $/{ }^{188}$ Os values are clearly related to crustal contamination [93], applying a filter would also eliminate a significant number of data sets at low Os ppt which have been demonstrated to not have suffered crustal contamination or seawater alteration $[74,80,83,94]$. An alternative to applying a filter is to look for correlations between Os isotopic values and other geochemical indicators of crustal contamination. In Figure $4 \mathrm{~d}$, Figures S9 and S10 there are no significant correlations between ${ }^{187} \mathrm{Os} /{ }^{188}$ Os values and LOI (Figure 4d), Re abundances (Figure S9a), Re/Os values (Figure S9b), Nb/U values (Figure S10a) and $\mathrm{Ce} / \mathrm{Pb}$ values (Figure S10b). Therefore, we are confident that the Os isotopic data presented in this paper are primary magmatic values and are not the result of either seawater alteration, crustal contamination or lithospheric interaction. We also note that thus far no crustal contamination process has been recognized that can produce subchondritic Os isotope ratios, as observed in LVS sample CH9.

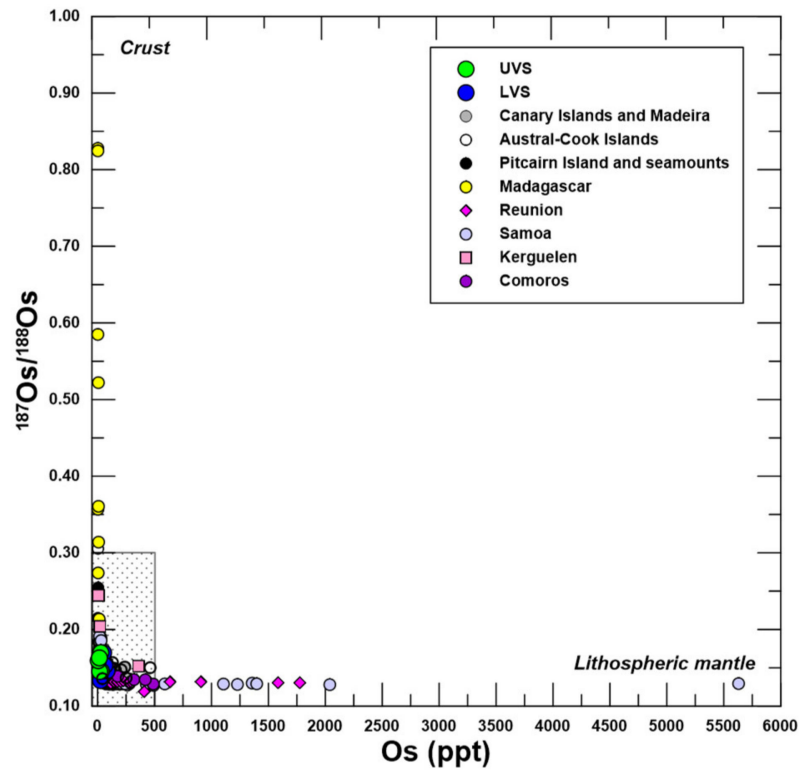

(a)

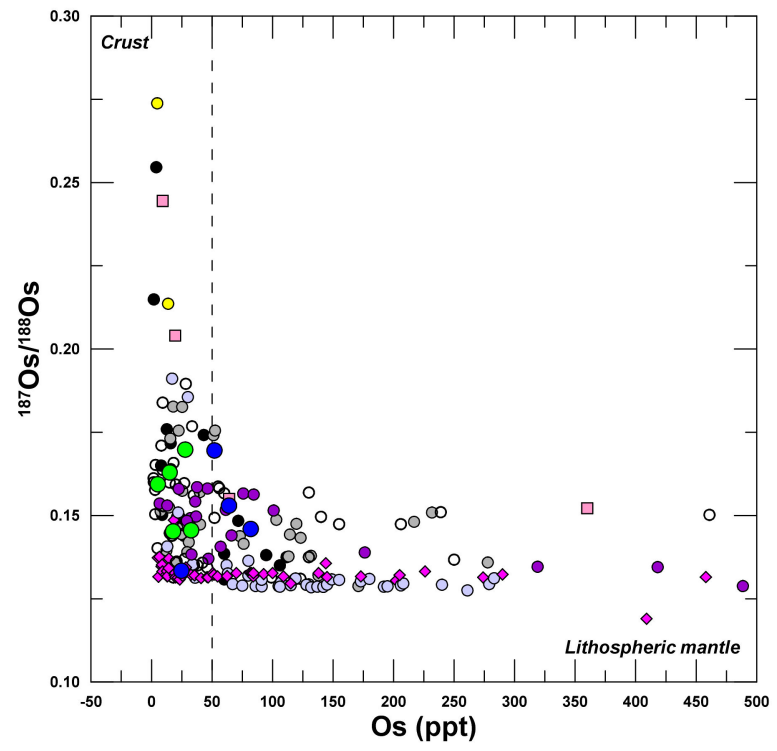

(b)

Figure 13. (a) ${ }^{187} \mathrm{Os} /{ }^{188} \mathrm{Os}$ versus Os (ppt) for the Christmas Island lava series compared to other intraplate lava suites, shaded rectangle is the area shown in (b). Symbols and data sources as for the legend to Figure 12 with the additional data and suites (see legend in (a)) as follows: Canary Islands and Madeira [79]; Pitcairn [91]; Austral-Cook [89,95]. The vertical dotted line in b) at Os 50 ppt is the proposed cut-off filter of [79] to eliminate crustally contaminated lavas. Typical lithospheric mantle ${ }^{187}$ Os $/{ }^{188}$ Os values vary between $0.105-0.135$ and Os (ppt) values vary from 500-5000 [35].

\subsection{Olivine Phenocryst Oxygen Isotopes}

Oxygen isotopes are also a very sensitive indicator of crustal contamination and post-magmatic fluid alteration $[50,96,97]$. The measured $\delta^{18} \mathrm{O}_{\mathrm{ol}(\mathrm{olivine})}$ values of olivine phenocrysts from both the LVS and UVS are almost identical (range in $\delta^{18} \mathrm{O}_{\mathrm{ol}}$ values 5.3-5.6) and only extend to slightly higher values than found in mantle peridotites $(5.2 \pm 0.2$; Figure 14). There is no correlation between initial Os isotope ratio and $\delta^{18} \mathrm{O}_{\mathrm{ol}}$ as observed in other studies $[98,99]$ and the full range of initial Os isotope ratios is present in samples with 
mantle type $\delta^{18} \mathrm{O}_{\mathrm{ol}}$. Only two samples from the older LVS have $\delta^{18} \mathrm{O}_{\mathrm{ol}}$ above the mantle range. Therefore, the olivine $\delta^{18} \mathrm{O}_{\mathrm{ol}}$ data from the Christmas Island lava series indicate that contamination and/or post-magmatic alteration cannot explain the range of Os isotopic values, which therefore must reflect the mantle Os isotopic composition.

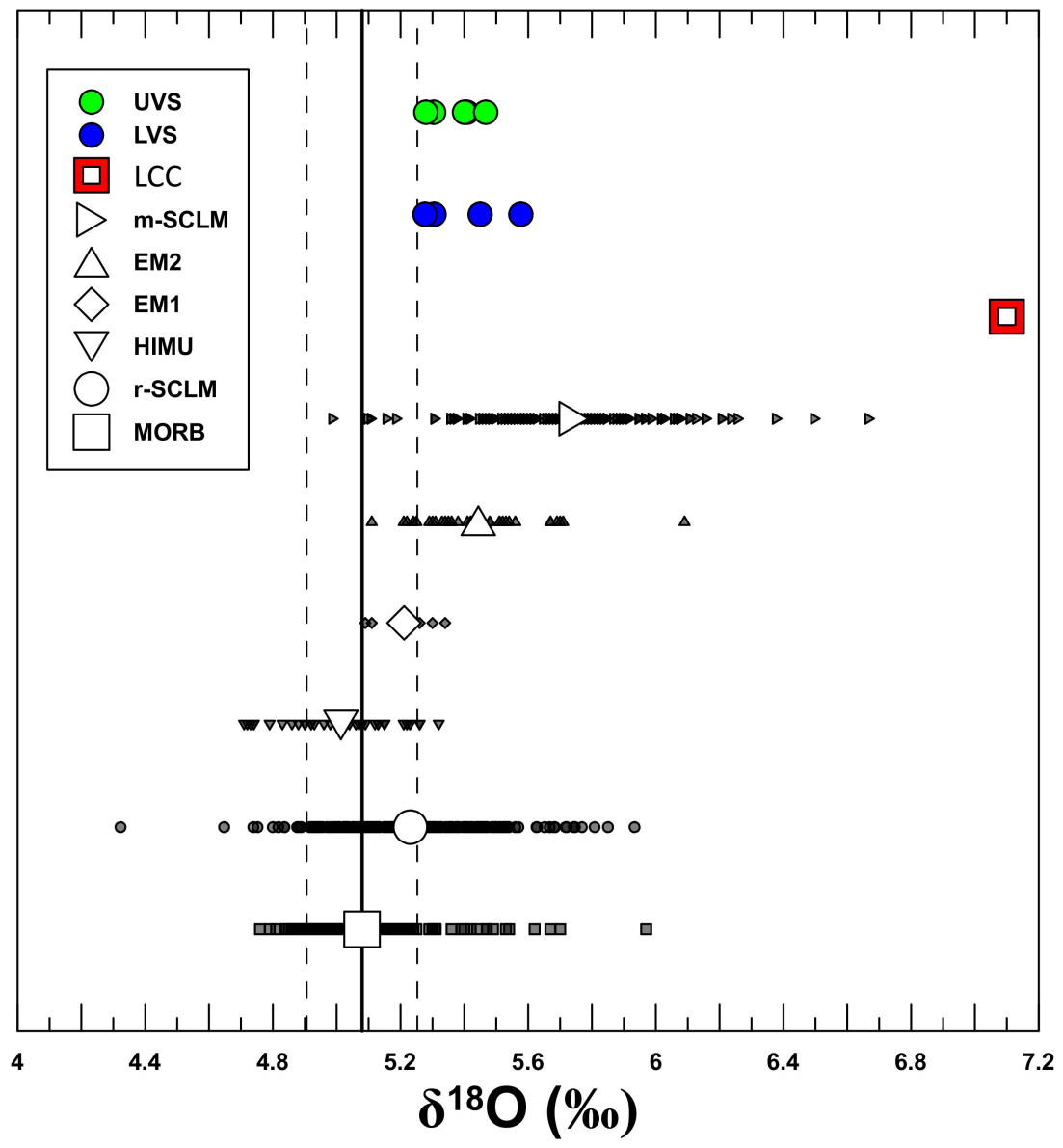

Figure 14. Olivine phenocryst $\delta^{18} \mathrm{O}$ (\% VSMOW-Vienna mean standard ocean water [50]) values for the Christmas Island lava series compared to the range and averages for other mantle derived lava series. A correction of -0.5 (\%) has been applied to glasses based on experimental and natural studies [50,96]. Data as follows: MORB glass, data points $n=198$ [96,100-104]; r-SCLM, refractorysubcontinental lithospheric mantle, data points $n=254$ [96,105-107]; HIMU, olivine phenocrysts, data points $n=41$ [96,108]; EM1, olivine phenocrysts, data points $n=8$ [106]; EM2, olivine phenocrysts, data points $n=32$ [96,109]; m-SCLM, metasomatized subcontinental lithospheric mantle, olivine phenocrysts and whole rocks, data points $n=147$ [107,110]; LCC, average lower continental crust, data points $n=74$; references [111,112]. The thick black vertical line is the MORB average and dashed black vertical lines are $\pm 1 \sigma$ standard deviation from this average.

\section{Discussion}

\subsection{Are the UVS an Example of Petit-Spot Volcanism?}

Petit-spot volcanism is a newly recognized form of intraplate volcanic phenomena occurring out board of oceanic trenches at the fore-bulge of the down-going subducting oceanic plate $[24,27,27,63,113-116]$. Petit-spot volcanism is believed to be the result of plate-flexure allowing the direct sampling of an underlying asthenosphere melt lying at the lithosphere-asthenosphere boundary (LAB) [117]. Thus petit-spot volcanism gives strong support for the long-standing idea that the LAB is defined and marked by the presence of a melt phase [116,118-121]. 
As previously stated by [10] the age of the UVS and occurrence on the outer rise of the down-going Indian plate at the Java Trench, is very similar to what has been reported from the Hokkaido Rise and Japan Trench [24,27] and thus the UVS, although erupted through an older volcanic edifice, appears to be another good example of petit-spot volcanism [10]. In Figures 8 and 9 we compare the major and trace element geochemistry of the UVS with other petit-spot lava (Hokkaido Rise, [27]; Western Pacific Seamount Province, [63]) and as well with lava associated with plate flexure (Samoa-Islands of Tuitila and Uo Mamae; Hawaii-North Arch Volcanic Field, [22,59]). In Figures 8 and 9 there is no uniformity in the geochemical compositions of lava associated with plate flexure, and as a result there is no exact match to the UVS of Christmas Island. For example, compared to the petit-spot lava of the Hokkaido Rise [27], the UVS has lower $\mathrm{SiO}_{2}, \mathrm{~K}_{2} \mathrm{O} \mathrm{TiO}_{2} \mathrm{Na}_{2} \mathrm{O}$; higher $\mathrm{CaO}$ and $\mathrm{Ba}$ abundances. However, in terms of NAPs the average UVS lava composition shows a striking similarity to averages for the Hokkaido Rise and Uo Mamae, especially with regards to peaks in $\mathrm{Ba}$ and $\mathrm{Pb}$. Although the UVS has a more pronounced Ba peak compared to Uo Mamae, all three suites have pronounced $\mathrm{Pb}$ peaks relative to $\mathrm{Ce}$ which is reflected in low $\mathrm{Ce} / \mathrm{Pb}$ (averages 13-15) values compared to other suites (Figure 15a). As well the UVS has very similar ( $\mathrm{Sr}-\mathrm{Nd}-\mathrm{Pb})$ isotopic values compared to Uo Mamae and the Hokkaido Rise (Figure 11). So, in summary, despite differences in parental magma compositions reflected in major elements, the UVS are very similar to petit-spot lava and lava associated with plate flexure in terms of NAPs and isotopic composition and most likely reflect similar enriched mantle components.

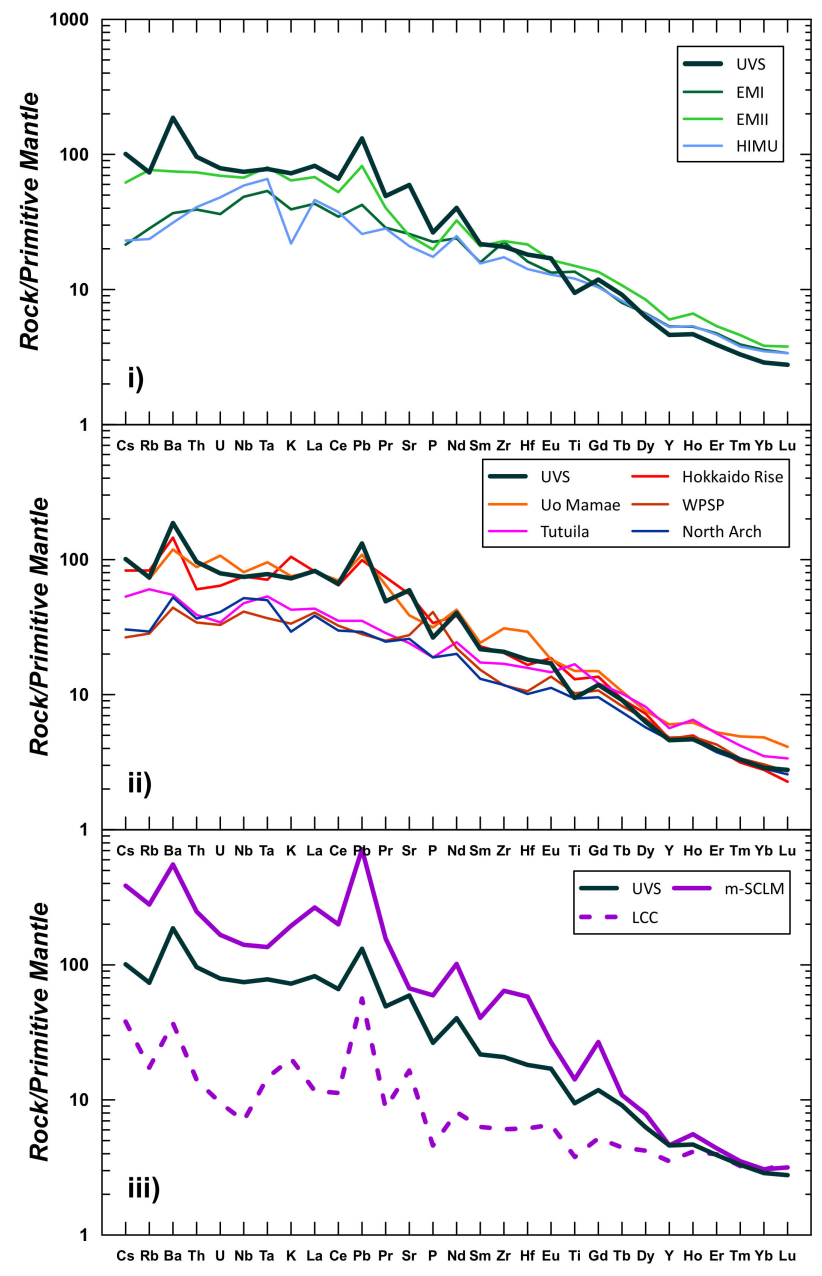

(a)

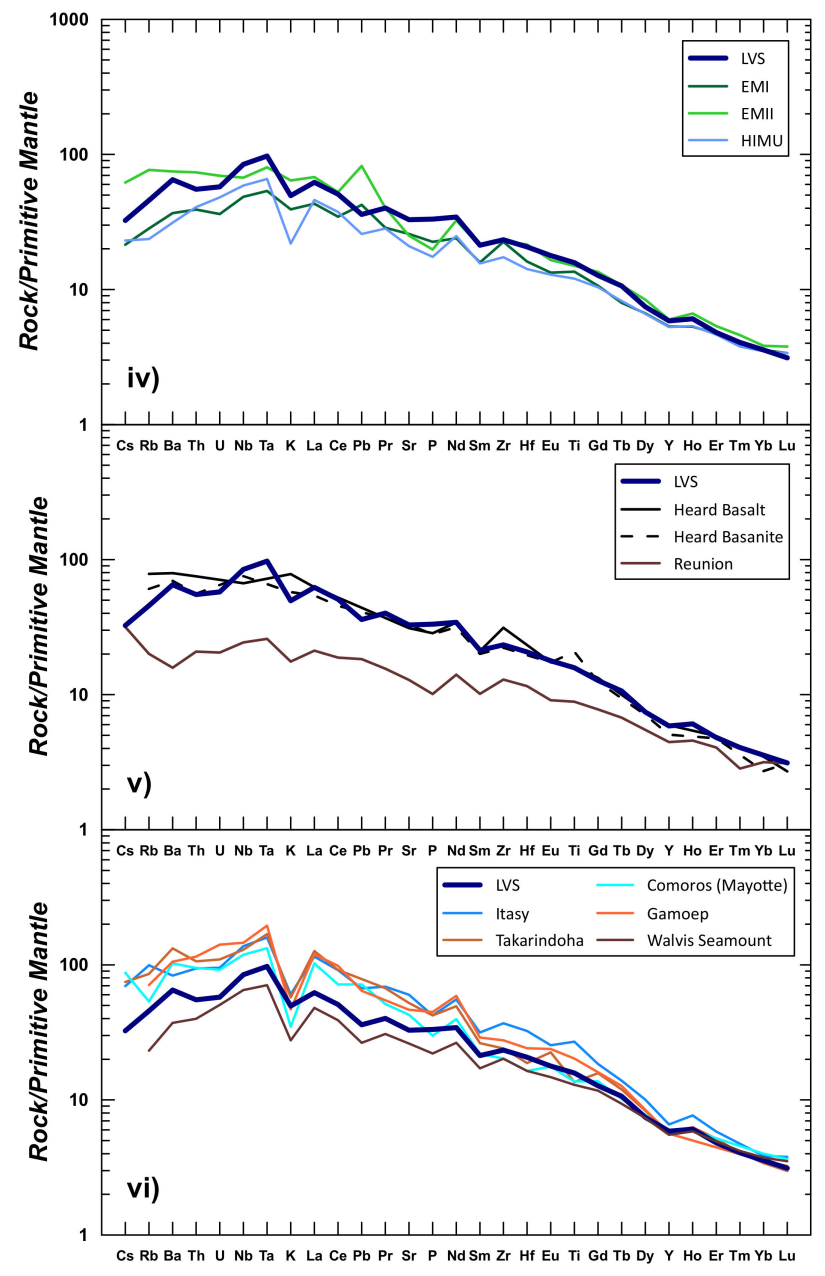

(b)

Figure 15. Primitive mantle normalized trace element abundance patterns for Christmas Island lava 
series: (a) the average ( $>9 \mathrm{wt} \% \mathrm{MgO}$ ) pattern for the Christmas Island UVS compared to other lava suites in the panels: (i) mantle end-members; (ii) petit-spot and lithospheric flexure -related suites and (iii) crustal and m-SCLM compositions; (b) the average ( $>9 \mathrm{wt} \% \mathrm{MgO}$ ) pattern for the Christmas Island LVS compared to other lava suits in the panels: (iv) mantle end-members; (v) Reunion and Kerguelen mantle plumes; (vi) African HIMU—related suites, and late-stage volcanism on the Walvis Ridge. Data sources and abbreviations as follows: HIMU-average $(n=14)>9 \mathrm{wt} \% \mathrm{MgO}$ lava from Mangaia Island [64]; EM1-average $(n=11)>9 \mathrm{wt} \% \mathrm{MgO}$ lava from Pitcairn Island and adjacent seamounts [65,66]; EMII-average $(n=6)>9 \mathrm{wt} \% \mathrm{MgO}$ lava from Savaii Island, Samoa [67]; Hokkaido Rise-average $(n=10)$ glasses and whole rocks (5-13 wt\% MgO; [27]); North Arch volcanic field—average $(n=17)>9 \mathrm{wt} \% \mathrm{MgO}$ lava [59]; Uo Mamae seamount-average $(n=4)>9 \mathrm{wt} \% \mathrm{MgO}$ lava [60-62]; Tutuila Island-average $(n=22)>9 \mathrm{wt} \% \mathrm{MgO}$ lava [22]; Western Pacific Seamount Province-average $(n=8)$ glass analyses [63]; m-SCLM is the average $(n=5)$ pattern for potassic lava derived from Gondwana Archean cratons. Data compilation as follows: Antarctica-average $(n=26)$ Gausberg lamproite [72]; Australian-average $(n=7)$ Mt. Bundey lamprophyre [122] and Western Australian olivine lamproite sample B20/1 [73]; Africa- average $(n=7)$ Finsch Mine micaceous kimberlite [73,123] and India-average $(n=2)$ Chelima lamproite [124]); Kerguelen—average $(n=9)$ Heard Island basaltic and average $(n=4)$ basanite series $>9 \mathrm{wt} \% \mathrm{MgO}$ [57]; Reunion-Piton de la Fournaise, average $(n=187)$ lava $>9 \mathrm{wt} \% \mathrm{MgO}$ [58]; Walvis Seamount-sample SO233-DR90-6 [125]; Comoros-average $(n=9)$ Mayotte South Domain lava [126]; Takarindoha-average $(n=34)$ olivine melilitite [127]; Itasy—primitive lava MI-16-16 [74]; Gamoep—average $(n=8)$ olivine melilitite [128].

An important unresolved question concerning petit-spot volcanism is whether the source of the magmas is derived directly from an ambient LAB melt phase [27] or whether petit-spot volcanism requires melt ponding at the LAB [116]. In the case of petit-spot volcanism on the Pacific Plate, outboard of the Chile Trench, Yamamoto et al. [116] suggested melt-ponding with melts derived from the nearby Juan Fernández mantle plume [116]. In Figure 16, we schematically illustrate another potential mechanism to produce melt ponding at the LAB during plate flexure. At position (1) (Figure 16a), lithospheric bending is expected to depress the lithosphere down at the pre-flexure point which might instigate brittle fracturing. As indicated by the arrow (1) (Figure 16b) the lithospheric bending is expected to cause a pressure induced breakdown of amphibole-which perhaps will cause enough melting to allow the production of petit-spot volcanism. As the oceanic plate passes over the bulge (position 2, Figure 16a), melt-freezing should occur as the mantle returns into the stability of amphibole (arrow (2), Figure 16b). This simple model can be tested if we have good constraints on the compositions of parental/primary melts for petit-spot lavas. 
a)

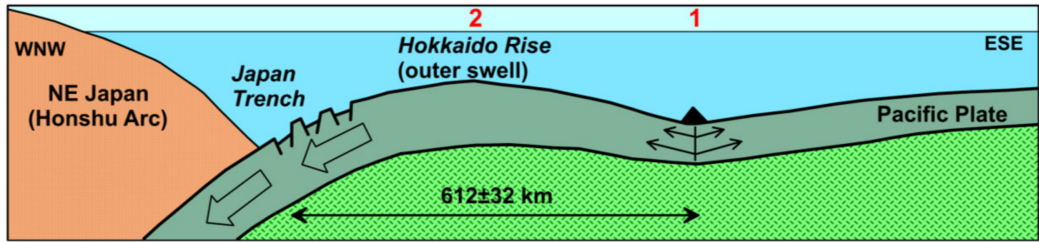

Temperature ${ }^{\circ} \mathrm{C}$

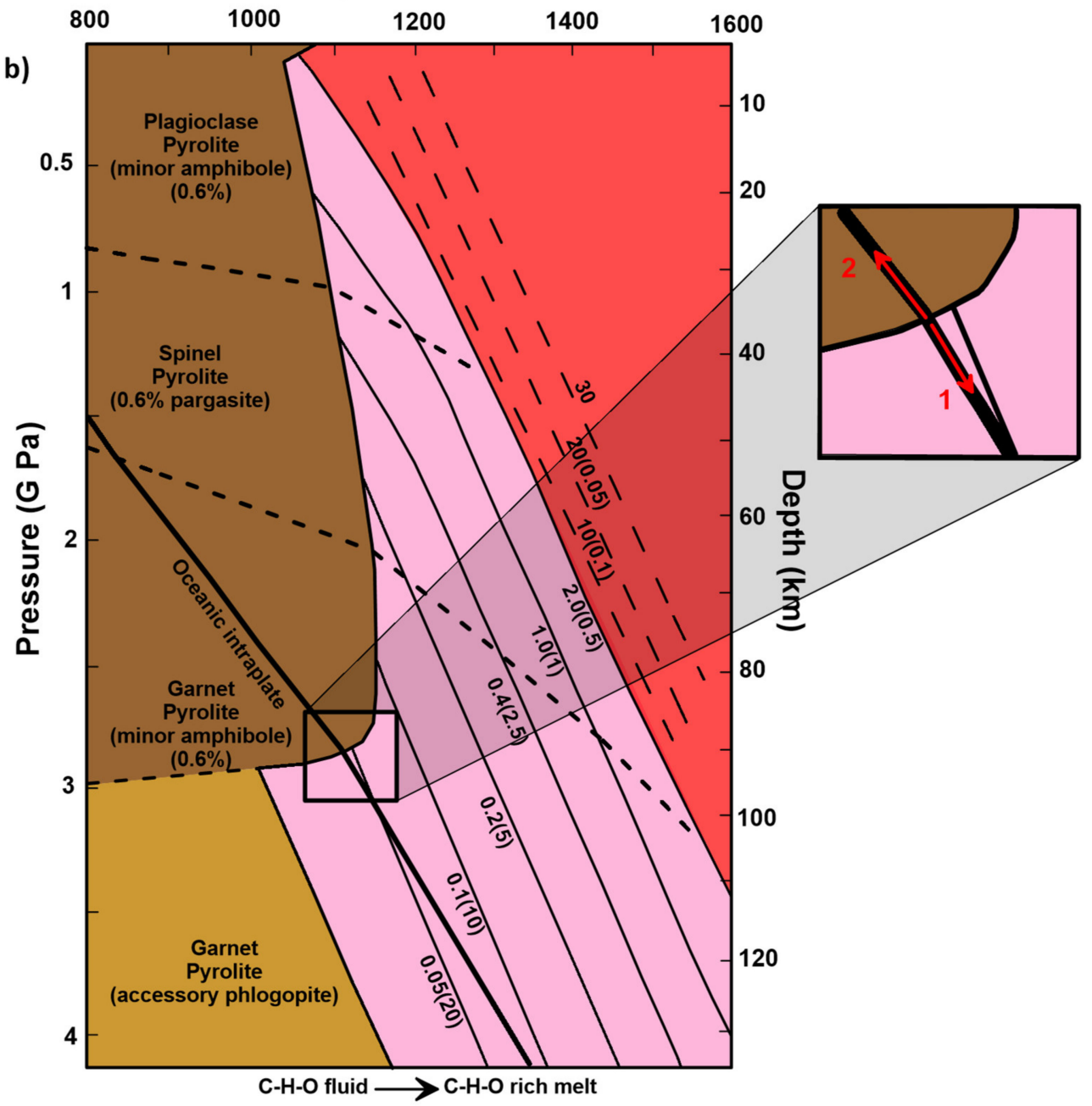

Figure 16. (a) Schematic outline of the 'plate flexure model' based on Figure 7 from [129]; (b) Experimentally determined pressure $(\mathrm{GPa})$ and temperature $\left({ }^{\circ} \mathrm{C}\right)$ phase relationships for pyrolite and pyrolite $+(\mathrm{C}+\mathrm{H}+\mathrm{O})$ containing 200 ppm $\mathrm{H}_{2} \mathrm{O}$ and 100 ppm $\mathrm{CO}_{2}$ (water-undersaturated conditions; $[130,131])$. The 'Oceanic intraplate' geotherm (thick black line) represents a geothermal gradient for old thick ocean crust, appropriate for petit-spot magmatism. If the oceanic lithosphere has $f \mathrm{O}_{2} \geq \mathrm{IW}+2 \log$ units, then the solidus along this geotherm is defined by paragasite dehydration melting which occurs at $\sim 90 \mathrm{~km}(\sim 2.7 \mathrm{GPa})$ at $\sim 1070{ }^{\circ} \mathrm{C}$ [132]. This intersection provides a petrological argument for a rheological change from lithosphere to asthenosphere with the presence of an incipient melt fraction (pink field $\% \mathrm{~F}<2 ; \% \mathrm{~F}>2$ is the 'major' melting regime in red, $\% \mathrm{~F}$ is weight fraction of melt expressed as a percentage). Dark and light brown fields are sub-solidus. Contours are marked with \%F and dissolved water content (in brackets). Dashed contours within the major melting regime are for volatile free melting (volatile contents are so low that they have no significant influence on melting relationships). Inset shows the change in phase relationships as the oceanic lithosphere undergoes lithospheric flexure. 
If petit-spot lava are derived from the $\mathrm{LAB}$, then their primary melts should be in equilibrium with the mantle at temperatures $\left(\sim 1175 \pm 50{ }^{\circ} \mathrm{C}\right.$; [133]) and pressures (appropriate to the age of the lithosphere, $100 \mathrm{Ma}=100 \mathrm{~km} \sim 3.0 \mathrm{GPa}, 81 \mathrm{Ma}=90 \mathrm{~km}$ $\sim 2.7 \mathrm{GPa}$; $[134,135])$ appropriate for the LAB. We therefore have used the whole rock and mineral composition of UVS sample 70453 and modelling using software Petrolog3 [136] to calculate a primary petit-spot melt (Table 4). Calculations used an oxygen fugacity of QFM + $0.5 \log$ units which is a suitable value for OIB magmas [137]. Further details of the mineral-melt equilibrium models used are presented in Tables 4 and S6. Mass balance calculations (Table S6) using the analyzed groundmass composition of 70454 (Table S3) and average olivine and clinopyroxene compositions indicate that the whole rock composition of 70453 contains $\sim 18 \mathrm{wt} \%$ olivine and $12 \mathrm{wt} \%$ clinopyroxene phenocrysts. Modelling with Petrolog3 software indicates that the whole rock composition of 70453 is representative of a parental liquid composition for the following reasons: (1) the calculated equilibrium olivine composition of the groundmass has an $\mathrm{Mg \#}$ of 85.1 matching the rim compositions of olivine phenocrysts (Mg\# 84-86) whereas the whole rock composition has a calculated equilibrium olivine composition of Mg\# 89.4 which is less than the maximum observed (Mg\# 90.4). This result indicates that it is unlikely that the whole rock composition of 70453 is the result of crystal accumulation; (2) modelling of fractional crystallization using the whole rock composition of 70453 can produce a reasonable match to the groundmass composition of 70454 with proportions and amounts of crystal phases extracted almost identical to the mass balance results (Table S6). In summary, we believe the whole rock composition of 70453 represents a parental melt composition and is a suitable composition for petrogenetic calculations as presented in Table 4 .

Table 4. Model Christmas Island parental liquids and estimates of potential petrogenetic conditions at 3-3.5 GPa.

\begin{tabular}{ccc}
\hline & UVS & LVS \\
\hline $\mathrm{SiO}_{2}$ & 42.92 & 45.72 \\
$\mathrm{TiO}_{2}$ & 2.19 & 2.78 \\
$\mathrm{Al}_{2} \mathrm{O}_{3}$ & 10.57 & 9.41 \\
$\mathrm{Fe}_{2} \mathrm{O}_{3}$ & 2.14 & 2.20 \\
$\mathrm{FeO}$ & 9.48 & 10.30 \\
$\mathrm{MnO}$ & 0.20 & 0.18 \\
$\mathrm{MgO}$ & 17.00 & 16.71 \\
$\mathrm{CaO}$ & 12.16 & 9.30 \\
$\mathrm{Na}{ }_{2} \mathrm{O}$ & 1.30 & 1.72 \\
$\mathrm{~K}_{2} \mathrm{O}$ & 1.44 & 1.17 \\
$\mathrm{P}_{2} \mathrm{O}_{5}$ & 0.59 & 0.49 \\
$\mathrm{Mg}$ & 0.726 & 0.708 \\
$\mathrm{H}_{2} \mathrm{O}$ & 2.38 & 1.66 \\
$\mathrm{CO}$ & 2.83 & 2.53 \\
$\mathrm{Temp}(0.2 \mathrm{GPa})$ & 1418 & 1415 \\
$\mathrm{Oliv} \mathrm{Eq}$ & 90.4 & 89.5 \\
$\%$ Oliv & 4.94 & 9.11 \\
Temp (3-3.5 GPa) & 1392 & 1551 \\
$\mathrm{~F}$ & 0.02 & 0.11 \\
$\mathrm{Tp}$ & 1360 & 1415 \\
\hline
\end{tabular}

As the most magnesian olivine composition analyzed has a Mg\# of 90.4 (Table S4) we use Petrolog3 to reverse olivine crystallization ( $5 \mathrm{wt} \%$, Table 4$)$ to calculate a parental magma (17 $\mathrm{wt} \% \mathrm{MgO}$ ) in equilibrium with this olivine (Table 4). This composition has a calculated anhydrous temperature at $0.2 \mathrm{GPa}$ of $1418^{\circ} \mathrm{C}$, which will obviously be lower, taking into account the presence of volatiles $\left(\mathrm{H}_{2} \mathrm{O}\right.$ and $\left.\mathrm{CO}_{2}\right)$.

The olivine mineral-melt model [138] oxygen fugacity model (QFM + 0.5 log units; [139]). See text for further details. 
As we have not determined the volatile contents for the Christmas Island lava series, we estimated the likely number of volatiles via natural and experimental constraints on similar alkaline compositions from other intraplate oceanic settings. We have therefore used a $\mathrm{H}_{2} \mathrm{O} / \mathrm{Ce}$ value of $200[140,141]$ to calculate a parental $\mathrm{H}_{2} \mathrm{O}$ content of $2.38 \mathrm{wt} \%$ (Table 4). We calculate $\mathrm{CO}_{2}$ contents by a $\mathrm{CO}_{2} / \mathrm{Nb}$ value of 505 [142] resulting in an estimated $\mathrm{CO}_{2}$ content of $2.83 \mathrm{wt} \%$. The resulting estimated $\mathrm{CO}_{2} / \mathrm{H}_{2} \mathrm{O}$ value of $\sim 1.2$ is consistent with natural OIB lava suites [143-145] and experimental studies of peridotitemelt equilibria [146-150]. Using these volatile abundances, we can apply an olivine liquidus depression for $\mathrm{H}_{2} \mathrm{O}$ of $\sim 55^{\circ} \mathrm{C} / 1 \mathrm{wt} \%$ (calculated from the experimental data of $[147,149]$ ) and for $\mathrm{CO}_{2}$ of $\sim 18^{\circ} \mathrm{C} / 1 \mathrm{wt} \%$ (calculated from the experimental data of [151]) to infer a temperature of $\sim 1236^{\circ} \mathrm{C}$ at $0.2 \mathrm{GPa}$ for the UVS parental magma.

To determine the pressure of mantle melting for the calculated UVS parental magma we project the composition into the CIPW normative tetrahedron and compare it with relevant experimental data at a range of pressures (Figure 17). The projected position of the UVS parental magma (Figure 17) is consistent with it being a melt in equilibrium with the mantle at pressures >3.0 GPa, significantly deeper than pressures expected for the LAB in the Indian Ocean ( 2.6 GPa; [135]). The UVS parental composition plots well away from the low-normative olivine compositions expected from the melting of amphibole bearing mantle compositions [152-154]. As the UVS parental magma composition plots between the anhydrous and $\mathrm{CO}_{2}$ bearing mantle melting cotectics at $3 \mathrm{GPa}[151,155]$ and the $\mathrm{H}_{2} \mathrm{O}$ bearing mantle melting cotectic at $4 \mathrm{GPa}$ [154], we infer a pressure of $\sim 3.5 \mathrm{GPa}$ for mantle equilibrium for the UVS primary melt (Figure 17). Using the $\mathrm{K}_{2} \mathrm{O}$ content of the parental UVS magma and MORB source mantle (MORB pyrolite $\mathrm{K}_{2} \mathrm{O} \sim 0.03 \mathrm{wt} \%$; [76,130]), we calculate that the UVS primary melt represents a $\mathrm{F}$ (weight fraction of melt) of 0.02 of a garnet lherzolite mantle composition. Using the $\mathrm{TiO}_{2}$ content of $\mathrm{MORB}$ pyrolite $(\sim 0.17 \mathrm{wt} \%)$ and the method of [151] we calculate a slightly higher melt fraction of $\sim 0.04$. To reconcile the two results the mantle source needs to be slightly more depleted with $\sim 0.13 \mathrm{wt} \% \mathrm{TiO}_{2}$. The relatively high primitive mantle normalised $(\mathrm{Dy} / \mathrm{Yb})_{\mathrm{N}}$ value of the parental UVS magma is 2.26 which is consistent with garnet being a residual phase in the mantle but is too high for a MORB source composition (e.g., DMM; [76]). Using the starting modal proportions of [89] for garnet lherzolite and the mineral-melt coefficients of [156], melting F 0.02 of a MORB source mantle only produces a melt with a $(\mathrm{Dy} / \mathrm{Yb})_{\mathrm{N}}$ value of 2.08. To be consistent with the calculated $\mathrm{F}$ using $\mathrm{K}_{2} \mathrm{O}$ abundances, the mantle source needs to be enriched in Dy relative to $\mathrm{Yb}$. This enrichment we believe reflects the nature of the mantle source to the UVS (see Section 4.4 below). Using Petrolog3 modelling and the calculated liquidus depression based on the inferred volatile contents (see above), we calculate a temperature of $\sim 1392{ }^{\circ} \mathrm{C}$ at a pressure of $3.5 \mathrm{GPa}$. Using the methods outlined in [157] this equates to a mantle potential temperature (Tp) of $\sim 1360{ }^{\circ} \mathrm{C}$.

Therefore, in summary, our calculated UVS primary melt is not consistent with a melt derived from the LAB but instead is consistent with an adiabatic mantle melting decompression path for normal MORB mantle (1375 $\pm 75^{\circ} \mathrm{C}$; [157-161]). Our results are consistent with the experimental study on Hokkaido Rise parental compositions [10,162], who suggest that petit-spot volcanism is the result of decompression melting of a buoyant mantle heterogeneity (Figure 17, see also Supplementary Discussion). Our results suggest that the lithospheric flexure of the oceanic plate must induce upwelling and subsequent decompression melting of randomly distributed enriched mantle heterogeneities, reflecting recycled metasomatized subcontinental lithospheric mantle possibly including small amounts of lower crust [10], within the shallow MORB asthenosphere. This explains why petit-spot volcanism is not ubiquitous along the flexural bends of subducting oceanic plates in agreement with previous studies $[75,116,162]$. 


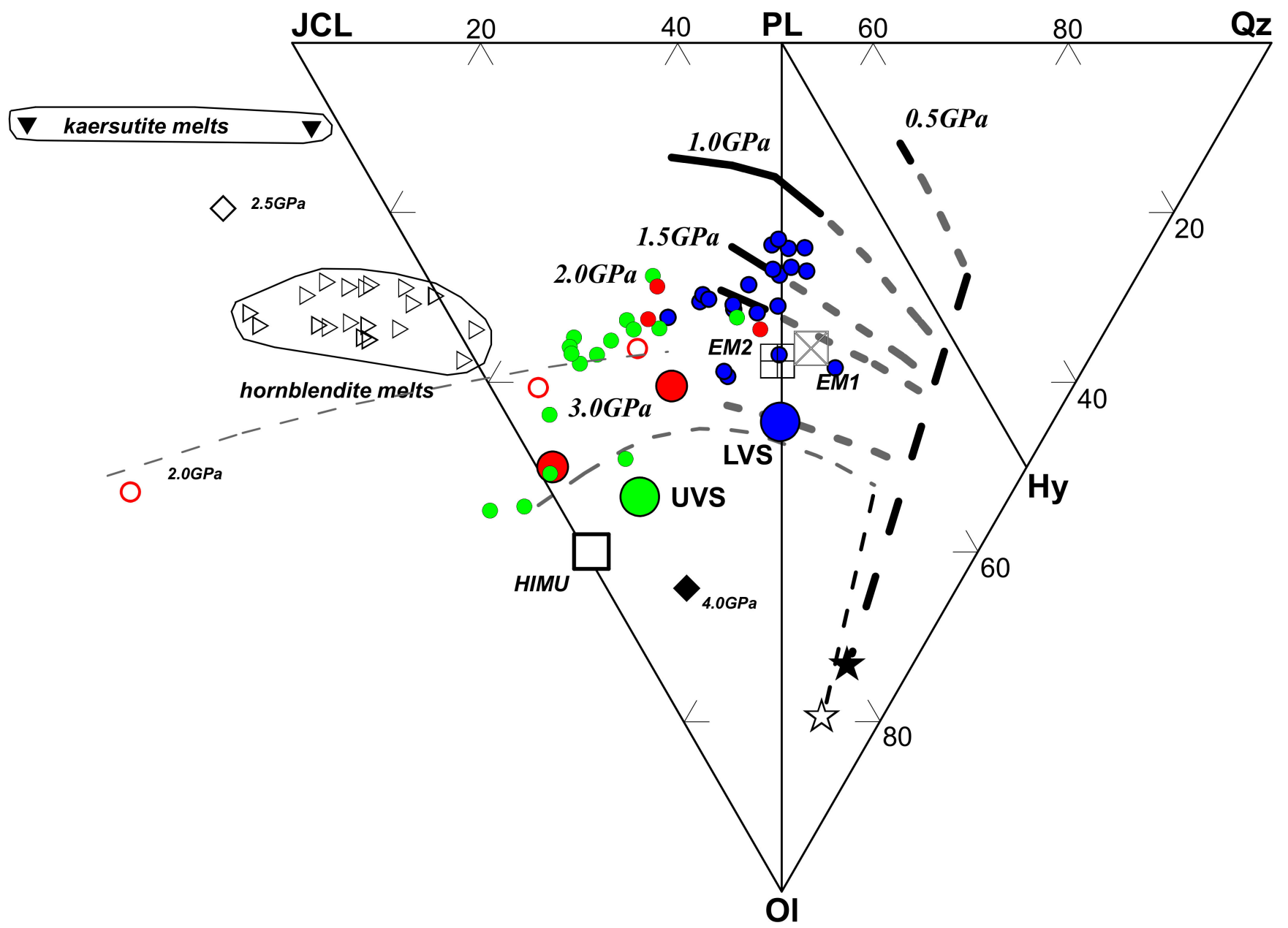

Figure 17. Calculated parental magmas for the Christmas Island lava series (Table 4, large green circle-UVS, large blue circle-LVS) and for petit-spot magmas from the Hokkaido Rise (large red circles; [162]) plotted in the projection from diopside onto the base of the CIPW molecular normative 'basalt tetrahedron'. Normative components as follows: Ol, olivine; Qz, quartz; Hy, hypersphene; $\mathrm{Pl}, \mathrm{Ab}+\mathrm{An}+\mathrm{Or}(\mathrm{Ab}$, albite; An, anorthite; Or, orthoclase); JCL, Jd + CaTs + Lc (Jd, jadeite; CaTs, Ca-Tschermaks; Lc, leucite). The position of the parental magmas is compared to experimentally determined melting cotectics for Hawaiian pyrolite (open star) from 0.5-3 GPa under nominally volatile free conditions [155] and for peridotite (PERC3; filled star) under $\mathrm{CO}_{2}$ under-saturated conditions at $3 \mathrm{GPa}$ [151]. Solid cotectic lines are melts in equilibrium with a lherzolite residue; grey dashed cotectic lines are melts in equilibrium with a harzburgite residue and black dashed cotectic lines are melts in equilibrium with a dunite residue. Other symbols and fields are as follows: small blue circles_LVS lava $>9 \mathrm{wt} \% \mathrm{MgO}$; small green circles-UVS lava $>9 \mathrm{wt} \% \mathrm{MgO}$; small filled red circles-petit-spot lava from the Hokkaido Rise with >9 wt\% MgO [27]; HIMU, EMI, EMII are calculated parental melts for mantle-end members from [56]); small red open circles are melts in equilibrium with harzburgite from the experiments of Machida et al. [162] (see also Supplementary Discussion); open and filled diamonds are the near-solidus melts for $\mathrm{HZ1}$ peridotite [163] under $\mathrm{H}_{2} \mathrm{O}$ saturated conditions at 2.5 and 4 GPa respectively [154]; right facing open triangles are experimentally determined melts of amphibole bearing mantle lithologies from [153]; filled upside triangles are natural glass in mantle xenoliths resulting from the melting of amphibole [152].

\subsection{Are the LVS Plume-Related Volcanism?}

Since in general, late-stage volcanism generally occurs within a few million years after the main volcanic phase at other hotspots (e.g., [18-20,164,165]), the long 41 Ma volcanic hiatus compared to the age of the seamounts of the VMP is of interest. Two possibilities 
are that the LVS is derived from a mantle plume and is thus unrelated to CHRISP or alternatively the LVS represents a late stage or delayed expression of the shallow-level recycling of CHRISP as outlined by [10].

To help answer this question, we have calculated a parental melt composition for the LVS using the whole rock composition of sample 70480 (Table 4, Figure 17) in a similar manner to the UVS (see above). Mass balance calculations (Table S6) using the analyzed groundmass composition of 70476 (Table S3) and average olivine, clinopyroxene and plagioclase compositions indicates that the whole rock composition of 70480 contains $\sim 19 \mathrm{wt} \%$ olivine, $\sim 12 \mathrm{wt} \%$ clinopyroxene and $\sim 1 \mathrm{wt} \%$ plagioclase phenocrysts. As was the case for 70453 , modelling with Petrolog3 software indicates that the whole rock composition of 70480 is also representative of a parental liquid as: (1) the calculated equilibrium olivine composition of the groundmass has an Mg\# of 79 matching the rim compositions of olivine phenocrysts ( $\mathrm{Mg \#} \mathrm{>} \mathrm{77),} \mathrm{whereas} \mathrm{the} \mathrm{whole} \mathrm{rock} \mathrm{composition} \mathrm{has} \mathrm{a} \mathrm{calculated} \mathrm{equilibrium}$ olivine composition of Mg\# 87.7, which is less than the maximum observed (Mg\# 89.5) and (2) modelling of fractional crystallization using the whole rock composition of 70480 can produce a very close matching to the groundmass composition of 70476 with proportions and amounts of crystal phases extracted almost identical to the mass balance results (Table S6). The calculated parental melt has $\sim 17 \mathrm{wt} \% \mathrm{MgO}$ in equilibrium with olivine Mg\# 89.5, which is the composition of the most magnesian olivine phenocryst analyzed in sample 70480, which we are confident is not xenocrystal (Figure 3, Table S4). As with the UVS we use a $\mathrm{H}_{2} \mathrm{O} / \mathrm{Ce}$ value of 200 to calculate a $\mathrm{H}_{2} \mathrm{O}$ content of $\sim 1.7 \mathrm{wt} \%$ and a $\mathrm{CO}_{2} / \mathrm{Nb}$ value of 505 to calculate a $\mathrm{CO}_{2}$ content of $\sim 2.5 \mathrm{wt} \%$ (Table 4 ). When projected into the CIPW normative tetrahedron (Figure 17), the parental composition plots at slightly lower pressures ( 3 GPa) compared to the UVS parental composition and towards $\mathrm{Hy}$, consistent with its higher calculated degree of partial melting of $\mathrm{F} \sim 0.11$, based on the $\mathrm{K}_{2} \mathrm{O}$ content of Hawaiian Pyrolite [130]. An OIB mantle source like Hawaii is appropriate for the LVS due to the similarity in olivine compositions as opposed to the MORB like olivine compositions of the UVS (Figure 3). Using the $\mathrm{TiO}_{2}$ content of Hawaiian pyrolite $(0.7 \mathrm{wt} \%)$ and the method of [151] we calculate a significantly higher melt fraction of $\sim 0.22$. To reconcile the two results the mantle source needs to have lower $\mathrm{TiO}_{2}$ abundances $(\sim 0.4 \mathrm{wt} \%)$ than Hawaiian pyrolite. As Hawaiian pyrolite is based on a Kilauea composition [130] it is more enriched in $\mathrm{TiO}_{2}$ than other OIB [166]. The high $(\mathrm{Dy} / \mathrm{Yb})_{\mathrm{N}}$ values of 2.16 for the parental LVS composition suggests garnet as a residual phase which in contrast to the UVS is inconsistent with the projected position of the LVS in the normative CIPW tetrahdron, which suggests equilibrium with a harzburgite residue (Figure 17). This inconsistency is a common problem amongst OIB magma suites $[131,166,167]$ and in the case of the LVS we believe it is due to the nature of the prior history of the recycled components in the mantle source (see Section 4.4 below). A pressure of $\sim 3.0$ GPa for the LVS is significantly higher than expected for the LAB at $41 \mathrm{Ma}$, if the LVS was erupted on normal oceanic crust with an age of $55 \mathrm{Ma}(\sim 2.5 \mathrm{GPa}, 81 \mathrm{~km} ;[10,168])$ and requires a mantle Tp of $\sim 1415^{\circ} \mathrm{C}$. This Tp is within the range of $1375 \pm 75^{\circ} \mathrm{C}$ proposed for normal mantle and is significantly lower than temperatures proposed for thermal plumes $\left(\mathrm{Tp}>1500{ }^{\circ} \mathrm{C}\right.$; [169]). So, in summary our petrogenetic calculations for a parental melt for the LVS strongly support the hypothesis that the LVS is the result of decompression melting of normal MORB mantle at $41 \mathrm{Ma}$, containing dispersed enriched heterogeneities like CHRISP. The ages of the LVS also overlap the timing of collision between the Australian and Indian plates at $40-45 \mathrm{Ma}$ resulting in a significant plate network reorganization [170]. Thus, regional plate tectonic stress may well have contributed to the origin of LVS magmatism.

\subsection{Are the LVS Related to Recycled Oceanic Crust?}

Hoernle et al. [10] noted that the LVS has affinities to E-MORB (enriched mid ocean ridge basalt) in terms of $\mathrm{Sr}-\mathrm{Nd}-\mathrm{Pb}-\mathrm{Hf}$ isotopes [10], suggesting recycling of young oceanic crust as a component in CHRISP. In this section we investigate whether the major and trace element geochemistry of the LVS is consistent with recycled oceanic crust or alternatively 
represents a heterogeneity due to pollution by major plumes in Indian Ocean, such as the Reunion (Reunion Island, $21^{\circ} 07^{\prime} \mathrm{S} 55^{\circ} 32^{\prime} \mathrm{E}$ ) and Kerguelen (Heard Island, $53^{\circ} 05^{\prime} \mathrm{S} 73^{\circ} 30^{\prime} \mathrm{E}$ ) plumes which could have potentially enriched the asthenospheric mantle source region of the Christmas Island lava $[57,171]$. In terms of major element and trace element abundances, the LVS lava compositions are very similar to lava from the currently active expression of the Kerguelen plume (Heard Island, Figures 8 and 9) and have higher $\mathrm{TiO}_{2}$ and, in general, have higher trace element abundances compared to Reunion (Figures 8 and 9). However, when average NAPs are compared (Figure 15b), the LVS are clearly distinct from both the Reunion and Kerguelen plumes in their marked enrichment in $\operatorname{HFSE}(\mathrm{Nb}, \mathrm{Ta})$ and relative depletion in LIL (Cs, $\mathrm{Rb}, \mathrm{K}$ ) and slight depletion in $\mathrm{Pb}$ relative to Ce (Figure 15b). In particular, the LVS lava have relatively high $\mathrm{Nb} / \mathrm{Rb}, \mathrm{Nb} / \mathrm{U}$ and $\mathrm{Ce} / \mathrm{Pb}$ values ( $2.34 \pm 0.73$ vs. $2.82 \pm 0.36$; $49.02 \pm 8.20$ vs. $44.05 \pm 6.19 ; 42.1 \pm 12.2$ vs. $31.9 \pm 2.3$; LVS vs. HIMU respectively) typical of HIMU derived lava [64,74,172]. Instead, the LVS NAPs (Figure 15b) are similar to NAPs for endmember HIMU [64], African HIMU suites (Figure 15b; [74,126-128,173,174]) and HIMU-type late-stage volcanism on the Walvis Ridge [125].

The HIMU signature carried in intraplate lava on and around the African continent is believed to be derived from the African LLSVP (large low s-wave velocity province; $[125,173,175])$. Therefore, the presence of this HIMU signature (young oceanic crust) in the Christmas Island LVS far from the African LLSVP is of interest. In the next section below (Section 4.4), we investigate two possibilities: (1) that the Christmas Island LVS represents shallow recycling of young oceanic crust (with HIMU trace element geochemistry and isotopic affinities similar to component $C$ of [78]) unrelated to the African HIMU suites, or (2) the Christmas Island LVS represents recycling of Gondwana lithospheric mantle, which has been cratonized by a long history of upwelling HIMU plume material (cf., [176]). During the break-up of Gondwana and the formation of the Indian Ocean, this lithospheric mantle has been incorporated into the developing Indian MORB by asthenospheric mantle flow [174,177-179].

\subsection{The Nature of Enriched Mantle Components}

As demonstrated by Hoernle et al. [10] the near-ridge seamount lava of CHRISP have strong DUPAL isotopic compositions as defined by Hart [43] $\left(\Delta^{208} \mathrm{~Pb} / \Delta^{204} \mathrm{~Pb}>+60\right.$ and ${ }^{87} \mathrm{Sr} /{ }^{86} \mathrm{Sr}>0.705$, Figure 11). The UVS are also strongly DUPAL and plot within the field of the VMP seamounts (Figure 11), however they also plot close to the composition of the extreme EM (defined by ${ }^{143} \mathrm{Nd} /{ }^{144} \mathrm{Nd}<0.512630$; [180]) Kerguelen plume (Figure 11). Hoernle et al. [10] explain the isotopic composition of the VMP lava as the result of shallow recycling of LCC and/or m-SCLM and as the UVS plot with the VMP in Figure 11, and as we have demonstrated are the result of shallow melting of a buoyant heterogeneity within the MORB mantle, it is reasonable to conclude that the mantle source for the UVS has been enriched with similar LCC and/or m-SCLM recycled components. However, it is also possible that the enrichment seen in the UVS is due to pollution by the Kerguelen Plume during the development on the Indian Ocean [181]. The ${ }^{87} \mathrm{Sr} /{ }^{86} \mathrm{Sr}$ and ${ }^{206} \mathrm{~Pb} /{ }^{204} \mathrm{~Pb}$ values of the UVS could also be explained by mixing between a C or HIMU type component with an enriched component similar to the Eastern Wharton Province Seamounts or the UVS (Figure 11b). As previously stated (Section 4.2), the nature of the enriched component is important to evaluate whether the LVS mantle source is an independent recycled component with HIMU-EM characteristics or reflects recycling of the Gondwana lithosphere (with HIMU characteristics) and/or Gondwana LCC components.

We test the above potential possibilities using the determined $\mathrm{Ce} / \mathrm{Pb}$ and $\gamma \mathrm{Os}$ values of the Christmas Island lava series (Figure 17$) . \mathrm{Ce} / \mathrm{Pb}$ values are a strong tracer of crustal sources due to the strong enrichment in $\mathrm{Pb}$ relative to the mantle [182-184]. Sims and DePaolo [185] demonstrate $\mathrm{Ce} / \mathrm{Pb}$ values can change due to plagioclase fractionation-as $\mathrm{Pb}$ is partitioned into plagioclase preferentially to Ce. If plagioclase fractionation has occurred, we would expect to find a strong negative linear relationship with $\mathrm{Eu} / \mathrm{Eu}^{*}$ [185], which is not observed in the Christmas Island lava (Figure S12). As there are no correlations 
with indices of alteration, and the samples being considered have $\mathrm{MgO}$ contents $>9 \mathrm{wt} \%$ we are confident that the $\mathrm{Ce} / \mathrm{Pb}$ values of Christmas Island lava plotted in Figure 18 are primary magmatic values. In contrast to $\mathrm{Ce} / \mathrm{Pb}, \gamma \mathrm{Os}$ values are a powerful tool to distinguish between crustal and lithospheric sources, due to the strong partitioning for Re into the crust and Os into the mantle [32,33,90-92,186]. Therefore, crustal sources will have positive $\gamma$ Os values in contrast to negative $\gamma$ Os for lithospheric mantle sources $[32,33]$.

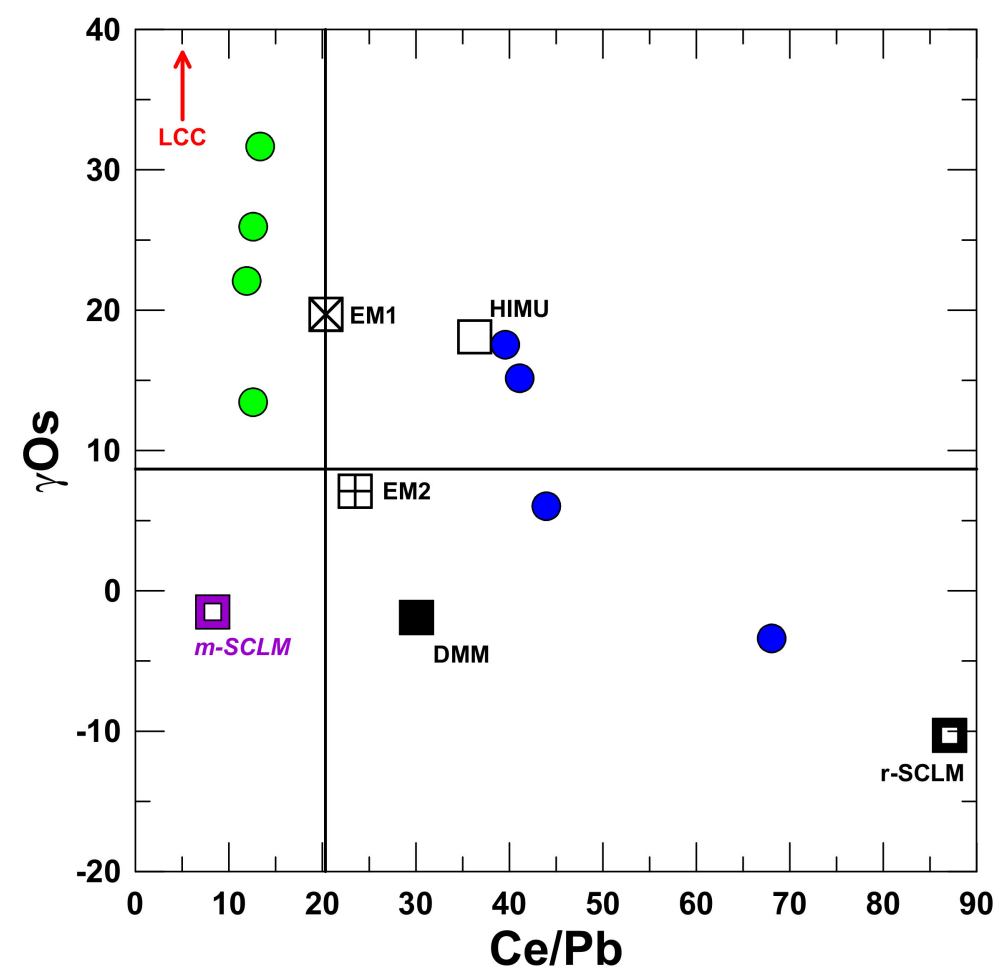

Figure 18. $\mathrm{Ce} / \mathrm{Pb}$ versus $\gamma \mathrm{Os}$ values of Christmas Island lava series. Data sources as follows: horizontal and vertical lines represent average Indian $\mathrm{N}-\mathrm{MORB}\left[(\mathrm{La} / \mathrm{Sm})_{\mathrm{N}}<1.0\right]-\mathrm{Ce} / \mathrm{Pb}$ value of 20.33 (average of $n=108$ ) calculated from the dataset of [55], $\gamma$ Os value of 8.68 is from [187]; $\gamma$ Os values for DMM, EM1, EM2 and HIMU are from [32]; m-SCLM-Ce/Pb value of 8.27 is the average for Western Australian lamproites [73], $\gamma$ Os value $=-1.5$ [35,43]; r-SCLM-refractory sub continental lithospheric mantle $-\mathrm{Ce} / \mathrm{Pb}$ value of 87.1 based on the modelling of [156], $\gamma$ Os value $=-10.3$ [35]; red arrow points to LCC $\gamma$ Os values of $>250[32,187]$ and $\mathrm{Ce} / \mathrm{Pb}$ values of $\sim 5$ [188]. Symbols as for the figure caption to Figure 11.

The UVS show a wide range in $+\gamma$ Os at relatively constant low $\mathrm{Ce} / \mathrm{Pb}$ values (Figure 18, UVS average 12.6). The UVS appear to form a steep almost vertical array lying between the composition of m-SCLM and LCC (Figure 18). The UVS array is displaced from the composition of Indian MORB mantle and extends to higher $+\gamma$ Os values than the EM1 mantle (Figure 18). These relationships strongly suggest that both m-SCLM and LCC are required to explain the enrichments in the UVS as opposed to enrichment by an EM plume such as Kerguelen. This observation is supported by the NAPs of the UVS compared to those for representative average compositions for m-SCLM and LCC (Figure 15a). The average NAP for the UVS plots in an intermediate position between m-SCLM and LCC suggesting a mixture between LCC and m-SCLM could explain the enrichments seen in the UVS (Figure 15a). The UVS NAP shares the same distinctive $\mathrm{Ba}$ and $\mathrm{Pb}$ peaks which can be seen in the NAPs for both LCC and m-SCLM (Figure 15a) but absent in the Kerguelen plume NAPs and EM1 mantle (Figure 15b).

The LVS $\gamma$ Os values correlate negatively with $\mathrm{Ce} / \mathrm{Pb}$ values (Figure 18) and Os isotope values range from $+\gamma$ Os $(\sim 17.5)$, similar to HIMU mantle, towards a more depleted mantle end-member with- $\gamma$ Os ( -3.4) values (Figure 18). The correlation between $\mathrm{Ce} / \mathrm{Pb}$ and 
$\gamma$ Os values of the LVS are inconsistent with asthenospheric mantle (e.g., Indian MORB, $\mathrm{DMM}$ ) being the high $\mathrm{Ce} / \mathrm{Pb}$ and $-\gamma \mathrm{O}$ end member. As pyroxenite is a component within refractory lithospheric mantle [32] we speculate that the high $\mathrm{Ce} / \mathrm{Pb}-\gamma \mathrm{O}$ s component in the LVS is derived from a pyroxenite component of refractory lithospheric mantle $(\mathrm{r}-$ SCLM, Figure 18). Based on the modelling of peridotite-pyroxenite melting of [156], we assign a $\mathrm{Ce} / \mathrm{Pb}$ value of 87.1 and a $\gamma \mathrm{Os}$ value of -10.3 based on the average value for on craton mantle xenoliths [35]. The presence of a r-SCLM component in the LVS lava gives strong support to the hypothesis that the LVS mantle source is not an isolated independent HIMU-EMI recycled component but is more likely to be the result of recycling of SCLM during breakup of Gondwana, specifically Greater India, Australia and the Burma block. This result supports the model of [10] that LCC and SCLM is distributed throughout the Indian Ocean due to Gondwana breakup. The model of [10] is also supported by the ages of zircons (2525-173Ma; [189]) obtained from gabbros recovered from the Central Indian Ridge (at $5^{\circ} 15^{\prime} \mathrm{S} 68^{\circ} 30^{\prime} \mathrm{E}$; [189]) suggesting episodic entrainment and dispersal of continental lithosphere during the breakup of Gondwana and the formation of the Indian Ocean crust [189].

Previous studies on Indian Ocean MORB and plumes in the South Atlantic and Indian ocean propose that three-component mixing is required to explain the range in DUPAL isotopic compositions observed [10,57,74,78,175,190-194]. In Figure 19 we qualitatively demonstrate the plausibility of three component mixing with respect to the petrogenesis of the Christmas Island lava series using ${ }^{87} \mathrm{Sr} /{ }^{86} \mathrm{Sr}$ and ${ }^{206} \mathrm{~Pb} /{ }^{204} \mathrm{~Pb}$ values (Figure 19). The end members in three-component mixing in most previous studies involve a mixture of (a) a plume component; (b) a depleted mantle component and (c) a continental component (LCC and/or SCLM).

In the case of the UVS, the three components that are plausibly required to fully encapsulate the range in isotopic values shown by lava compositions are (a) SCLM derived from Gondwana lithosphere, with an intermediate composition between r-SCLM and m-SCLM, (b) LCC from Gondwana lower crust and (c) ambient Indian MORB mantle (Figure 19, green shaded triangle). No plume component is required or is a suitable component to explain the isotopic values of the UVS lava (Figure 19). This observation agrees with other studies, which propose that the enrichments present in petit-spot lava are the result of ubiquitous shallow-level enrichment of MORB source mantle by continental components $[10,75,195]$.

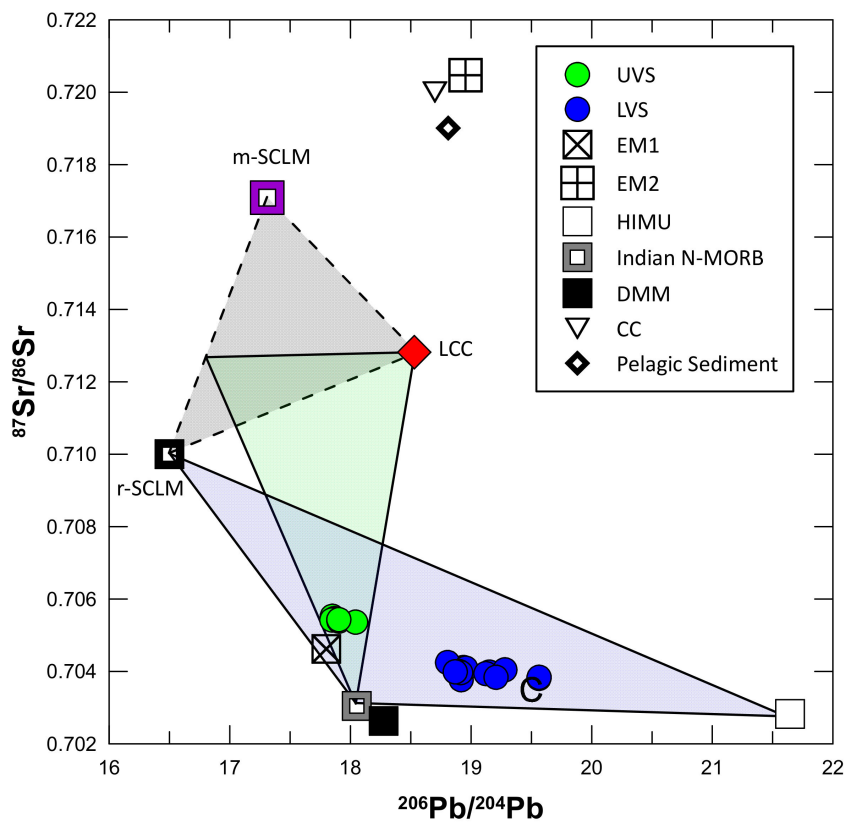

Figure 19. A proposed three component mixing model for the Christmas Island lava series schematically 
outlined in ${ }^{87} \mathrm{Sr} /{ }^{86} \mathrm{Sr}$ versus ${ }^{206} \mathrm{~Pb} /{ }^{204} \mathrm{~Pb}$ isotopic space (see text for details). Data sources as follows: Indian MORB, average $(n=157) \mathrm{N}-\mathrm{MORB}$ Indian glasses where $\mathrm{Sr}-\mathrm{Nd}-\mathrm{Pb}$ isotopes were analyzed on the same glass sample [70]; DMM, [76]; m-SCLM average Western Australian olivine lamproite [73]; r-SCLM [74]; EMII, Savaii, most isotopically enriched whole rock sample D115-21 [67]; EM1, average $(n=11)>9 \mathrm{wt} \% \mathrm{MgO}$ lava from Pitcairn Island and adjacent seamounts [65,66]; HIMU, average $(n=14)>9 \mathrm{wt} \% \mathrm{MgO}$ lava from Mangaia Island [64]; Component "C" [78]; Modern Pelagic sediment [196]; CC—average modern continental crust [172]; LCC—lower continental crust, average $(n=89)$ granulites [197-201]. LVS, and UVS lava >9 wt\% MgO (Table 2; [10,43]).

In the case of the LVS, the three components that are plausibly required to fully encapsulate the range in isotopic values shown by the lava compositions (Figure 19) are (a) a HIMU component, (b) r-SCLM derived from Gondwana lithospheric mantle and (c) ambient Indian MORB mantle. The HIMU component could either be young recycled oceanic crust [10] or potentially a mantle plume component incorporated into Gondwana lithospheric mantle during cratonization [176].

\section{Conclusions}

(1) The variable Os isotopic compositions of the Christmas Island lava series, extending from subchondritic to superchondritic values but none have typical MORB type Os isotope values, are consistent with DUPAL components being present in Indian Ocean upper mantle. These components are likely to reflect the presence of recycled LCC and/or SCLM components within the ambient Indian MORB mantle due to Gondwana break-up and continental drift [10].

(2) The geochemistry of the UVS lava of Christmas Island is consistent with a petrogenesis involving shallow-level melting of Indian MORB source mantle enriched with both LCC and SCLM components. The enrichment of the Indian MORB mantle by plume components, such as the EM1 Kerguelen mantle, is not required to explain the enriched trace element and isotopic composition of the UVS. This is supported by the MORB like olivine compositions (Mg\#, Ni ppm) of the UVS and olivine $\delta^{18} \mathrm{O}$ values, which are similar to m-SCLM. Calculated primary mantle-derived melts for the UVS petitspot lava are inferred to result from decompression melting along a MORB mantle adiabat of $\sim \mathrm{Tp} 1360{ }^{\circ} \mathrm{C}$ with melt segregation at $\sim 3.5 \mathrm{GPa}$. They do not originate from the LAB, although lithospheric flexure clearly plays a role in causing upwelling and the melting of small-scale heterogeneities present in the asthenospheric MORB source mantle as suggested by [10].

(3) The geochemistry of the LVS is consistent with recycling plume and SCLM components related to Gondwana break-up. Calculated primary mantle-derived melts for the LVS lava require a MORB like adiabat of Tp $1415{ }^{\circ} \mathrm{C}$ along with the Os isotopic evidence for the presence of r-SCLM supports the proposed idea that continental breakup causes recycling of lithospheric components into the ambient MORB mantle. As the LVS end member with radiogenic $\mathrm{Pb}$ represents a shallow recycled component, it provides a satisfactory explanation as to why there is no associated hotspot track or LIP associated with the LVS.

Supplementary Materials: The following are available online at https: / www.mdpi.com/article/ 10.3390/geosciences12030118/s1, Supplementary Discussion: (1) Geology and Regional Setting, (2) Osmium Analytical Techniques and (3) Petit-spot volcanism, References [202-222] are cited in the supplementary materials. Figure S1: Bathymetric map of the Christmas Island Seamount Province (CHRISP) summarizing seafloor morphology and Ar/Ar ages in millions of years, Table S1: Dredge locations yielding rock material during the RV Franklin 1987 voyage (expedition FR 9/87), Figure S2: A simplified geological map of Christmas Island, Table S2: Field notes and sample locations of Christmas Island volcanic rocks, Figure S3: A simplified stratigraphic column for exposed rocks on Christmas Island based on palaeontologic and stratigraphic studies, Table S3: Representatitve mineral chemistry from Christmas Island volcanic rocks, Figure S4: Schematic figure showing the 
sea-level curve of [216], Table S4: Olivine and Clinopyroxene mineral chemistry from Christmas Island volcanic rocks, Figure S5: Pillow lavas (A) and hyloclastite breccia and broken pillows (B) of the Pliocene-aged Upper Volcanic Series-exposed in the Egeria Point Peninsula of Christmas Island, Table S5: Geochemistry of volcanic rocks from Christmas Island, Figure S6: Bathymetric map of the area Southwest of Christmas Island showing the location of dredge stations during voyage FR9_87 of the RV Franklin, Table S6: Mass balance and Petrolog3 modelling results for Christmas Island lavas, Figure S7: A comparison of trace element abundances in Christmas Island lava series as determined by XRF versus ICPMS/INAA methods, Figure S8: The CHRISP volcanism displays a large range in isotopic composition, Figure S9: The ${ }^{187} \mathrm{Os} /{ }^{188} \mathrm{Os}$ values of the Christmas Island lava series versus (a) Re (ppt) and (b) $\mathrm{Re} / \mathrm{Os}$ values, Figure S10: The $\mathrm{Ce} / \mathrm{Pb}(\mathbf{a})$ and $\mathrm{Nb} / \mathrm{U}(\mathbf{b})$ versus ${ }^{187} \mathrm{Os} /{ }^{188}$ Os values for the Christmas Island lava series, Figure S11: Pressure (GPa) and temperature $\left({ }^{\circ} \mathrm{C}\right)$ for parental petit-spot magmas from the Hokkaido Rise, northwestern Pacific, Figure S12: $\mathrm{Ce} / \mathrm{Pb}$ vs $\mathrm{Eu} / \mathrm{Eu}^{*}$ values of the Christmas Island lava series.

Author Contributions: T.J.F. and K.H. conceived the project, collected samples and wrote the first versions of the manuscript. T.J.F., K.H., B.F.S., I.N.B., S.R.H., D.G.-S. and R.A.D. provided data and contributed to the final interpretation of the data and writing of the paper. All authors have read and agreed to the published version of the manuscript.

Funding: This research received no external funding.

Acknowledgments: We acknowledge the analytical and technical assistance of Simon Stephens, Katie McGoldrick, Philip Robinson, Wieslav Jablonski, Andrew McNeill (University of Tasmania) and Helen Waldron (Becquerel). Samples XI-1 to XI-5 were collected and provided by Bruce Tomich, The Phosphate Mining Company of Christmas Island, Ltd. We thank Julie Morris for help with isotope analyses. Thanks to the captain, Neil Cheshire, and crew of RV Franklin for their help in dredging operations during cruise FR9_87. This research was supported by an Australian National Research Fellowship to Trevor Falloon, the German Ministry of Education and Research (BMBF) and GEOMAR for financial support of the SO199 CHRISP project, Australian Research Council funding to Bruce Schaefer, Rick Varne (deceased) and Falloon, Australian National Marine Facility support to Rick Varne for the use of RV Franklin, NSF grant OCE88-12143 to Robert Duncan and NSF grant nos. EAR8308809 and EAR8708372 to Stan Hart. This paper is dedicated to the memory of Rick Varne, late Emeritus Professor at the University of Tasmania.

Conflicts of Interest: The authors declare no conflict of interest.

\section{References}

1. Wessel, P.; Sandwell, D.T.; Kim, S.S. The global seamount census. Oceanography 2010, 23, 24-33. [CrossRef]

2. Morgan, W.J. Convection plumes in the lower mantle. Nature 1971, 230, 42-43. [CrossRef]

3. Morgan, W.J. Deep mantle convection plumes and plate motions. AAPG Bull. 1972, 56, 203-213. [CrossRef]

4. Morgan, W.J. Hotspot tracks and the opening of the Atlantic and Indian Oceans. In The Sea, The Oceanic Lithosphere; Emiliani, C., Ed.; Wiley Interscience: New York, NY, USA, 1981; Volume 7, pp. 443-487.

5. Wilson, J.T. A possible origin of the Hawaiian Islands. Can. J. Phys. 1963, 41, 863-870. [CrossRef]

6. Duncan, R. Age progressive volcanism in the New England seamounts and the opening of the Central Atlantic Ocean. J. Geophys. Res. 1984, 89, 9980-9990. [CrossRef]

7. Richards, M.A.; Duncan, R.A.; Courtillot, V.E. Flood basalts and hot-spot tracks: Plume heads and tails. Science 1989, 246, 103-107. [CrossRef] [PubMed]

8. McNutt, M.K.; Caress, D.W.; Reynolds, J.; Jordahl, K.A.; Duncan, R.A. Failure of plume theory to explain mid plate volcanism in the southern Austral islands. Nature 1997, 389, 479-482. [CrossRef]

9. Ballmer, M.D.; Ito, G.; van Hunen, J.; Tackley, P.J. Small-scale sub lithospheric convection reconciles geochemistry and geochronology of 'Superplume' volcanism in the western and south Pacific. Earth Planet. Sci. Lett. 2010, 290, 224-232. [CrossRef]

10. Hoernle, K.; Hauff, F.; Werner, R.; van den Bogaard, P.; Gibbons, A.D.; Conrad, S.; Muller, R.D. Origin of Indian Ocean Seamount Province by shallow re-cycling of continental lithosphere. Nat. Geosci. 2011, 4, 883-887. [CrossRef]

11. Yan, Q.; Milan, L.; Saunders, J.E.; Shi, X. Petrogenesis of basaltic lavas from the West Pacific Seamount Province: Geochemical and Sr-Nd-Pb-Hf isotopic constraints. J. Geophys. Res. Solid Earth 2021, 126, e2020JB021598. [CrossRef]

12. Hieronymus, C.F.; Bercovici, D. Non-hotspot formation of volcanic chains: Control of tectonic and flexural stresses on magma transport. Earth Planet. Sci. Lett. 2000, 181, 539-554. [CrossRef]

13. Koppers, A.A.; Staudigel, H.; Pringle, M.S.; Wijbrans, J.R. Short-lived and discontinuous intraplate volcanism in the South Pacific: Hot spots or extensional volcanism? Geochem. Geophys. Geosyst. 2003, 4, 1-49. [CrossRef] 
14. Natland, J.H.; Winterer, E.L. Fissure control on volcanic action in the Pacific. In Special Papers of the Geological Society of America; Geological Society of America: Boulder, CO, USA, 2005; Volume 388, pp. 687-688.

15. Long, X.; Geldmacher, J.; Hoernle, K.; Hauff, F.; Wartho, J.A.; Garb-Schonberg, C.D. Origin of isolated seamounts in the Canary Basin (East Atlantic): The role of plume material in the origin of seamounts not associated with hotspot tracks. Terra Nova 2020, 32, 390-398. [CrossRef]

16. Wei, X.; Shi, X.F.; Xu, Y.G.; Castillo, P.R.; Zhang, Y.; Zhang, L.; Zhang, H. Mid-Cretaceous Wake seamounts in NW Pacific originate from secondary mantle plumes with Arago hotspot composition. Chem. Geol. 2022, 587, 120632. [CrossRef]

17. GeoMapApp. Marine Geoscience Data System. 2021. Available online: http://www.geomapapp.org/ (accessed on 1 December 2021).

18. Clague, D.A.; Dalrymple, G.B. The Hawaiian-Emperor volcanic chain. Part I. Geologic evolution. In Volcanism in Hawaii; U.S. Geological Survey: Reston, VA, USA, 1987; Volume 1, pp. 5-54.

19. White, W.M.; Duncan, R.A. Geochemistry and geochronology of the Society Islands: New evidence for deep mantle recycling Geophys. Monogr. 1996, 95, 183-206.

20. Garcia, M.O.; Swinnard, L.; Weis, D.; Greene, A.R.; Tagami, T.; Sano, H.; Gandy, C.E. Petrology, geochemistry and geochronology of Kaua'I lavas over 4 5Myr: Implications for the origin of Rejuvenated volcanism and the evolution of the Hawaiian Plume. $J$. Petrol. 2010, 51, 1507-1540. [CrossRef]

21. Krishna, K.; Bull, J.; Ishizuka, O.; Scrutton, R.; Jaishankar, S.; Banakar, V. Growth of the Afanasy Nikitin seamount and its relationship with the 85 E Ridge, north-eastern Indian Ocean. J. Earth Syst. Sci. 2014, 123, 33-47. [CrossRef]

22. Reinhard, A.A.; Jackson, M.G.; Blusztajn, J.; Koppers, A.A.P.; Simms, A.R.; Konter, J.G. "Petit Spot" rejuvenated volcanism superimposed on plume-derived Samoan shield volcanoes: Evidence from a 645-m drill core from Tutuila Island, America Samoa. Geochem. Geophys. Geosyst. 2019, 20, 1485-1507. [CrossRef]

23. Jackson, M.G.; Halldorsson, S.A.; Price, A.; Kurz, M.D.; Konter, J.G.; Koppers, A.A.P.; Day, J.M.D. Contrasting Old and Young Volcanism from Aitutaki, Cook Islands: Implications for the Origins of the Cook-Austral Volcanic Chain. J. Petrol. 2020, 61, egaa037. [CrossRef]

24. Hirano, N.; Sumino, H.; Morishita, T.; Machida, S.; Kawano, T.; Yasukawa, K.; Hirata, T.; Kato, Y.; Ishii, T. A Paleogene magmatic overprint on Cretaceous seamounts of the western Pacific. Isl. Arc 2021, 30, e12386. [CrossRef]

25. Hamilton, W. Tectonics of the Indonesian region. In USGS Professional Paper; Geological Society of America: Boulder, CO, USA, $1979 ; 345 p$.

26. Raghuram, G.; Capitanio, F.A.; Radhakrishna, M. Flexural analysis along the Sunda Trench: Bending, buckling and plate coupling. Tectonics 2018, 37, 3524-3544. [CrossRef]

27. Hirano, N.; Takahashi, E.; Yamamoto, J.; Machida, S.; Abe, N.; Ingle, S.; Kaneoka, I.; Hi-rata, T.; Kimura, J.; Ishii, T.; et al. Volcanism in response to plate flexure. Science 2006, 313, 1426-1428. [CrossRef]

28. Walker, R.J.; Carlson, R.W.; Shirey, S.B.; Boyd, F.R. Os, Sr, Nd and Pb isotope systematics of Southern African peridotite xenoliths: Implications for the chemical evolution of subcontinental mantle. Geochim. Cosmochim. Acta 1989, 53, 1583-1595. [CrossRef]

29. Schaefer, B.F. Radiogenic Isotope Geochemistry: A Guide for Industry Professionals; Cambridge University Press: Cambridge, UK, 2016. [CrossRef]

30. Ellam, R.M.; Carlson, R.W.; Shirey, S.B. Evidence from Re-Os isotopes for plume-lithosphere mixing in Karoo flood basalt genesis. Nature 1992, 359, 718-720. [CrossRef]

31. Pearson, D.G.; Shirey, S.B.; Carlson, R.W.; Boyd, F.R.; Pokhilenko, N.P.; Shimizu, N.; Sobolev, N.V. Re-Os, Sm-Nd and Rb-Sr isotope evidence for thick Archean lithosphere beneath Siberia modified by multi-stage metasomatism. Geochim. Cosmochim. Acta 1995, 59, 959-977.

32. Shirey, S.B.; Walker, R.J. The Re-Os isotope system in cosmochemistry and high-temperature geochemistry. Annu. Rev. Earth Planet. Sci. 1998, 26, 423-500. [CrossRef]

33. Lassiter, J.C.; Hauri, E.H. Osmium-isotope variations in Hawaiian lavas: Evidence for recycled oceanic lithosphere in the Hawaiian plume. Earth Planet. Sci. Lett. 1998, 164, 483-496. [CrossRef]

34. Graham, S.; Lambert, D.D.; Shee, S.R.; Smith, C.B.; Reeves, S. Re-Os isotopic evidence for Archean lithospheric mantle beneath the Kimberley block, Western Australia. Geology 1999, 27, 431-434. [CrossRef]

35. Pearson, D.G.; Canil, D.; Shirey, S.B. Mantle samples included in volcanic rocks: Xenoliths and diamonds. In The Mantle and Core; Treatise on Geochemistry; Carlson, R.W., Ed.; Elsevier-Pergamon: Oxford, UK, 2003; Volume 2, pp. 171-275.

36. Hart, S.R. A large-scale isotope anomaly in the Southern Hemisphere mantle. Nature 1984, 309, 753-757. [CrossRef]

37. Renne, P.R.; Swisher, C.C.; Deino, A.L.; Karner, D.B.; Owens, T.L.; DePaolo, D.J. Intercalibration of standards, absolute ages and uncertainties in ${ }^{40} \mathrm{Ar} /{ }^{39} \mathrm{Ar}$ dating. Chem. Geol. 1998, 145, 117-152. [CrossRef]

38. Wijbrans, J.R.; Pringle, M.S.; Koppers, A.A.P.; Scheevers, R. Argon geochronology of small samples using the Vulkaan argon laser probe. Proc. K. Ned. Akad. Wet. Biol. Chem. Phys. Med. Sci. 1995, 98, 185-218.

39. Steiger, R.H.; Jager, E. Subcommission on geochronology: Convention of the use of decay constants in geo- and cosmochronology. Earth Planet. Sci. Lett. 1977, 36, 359-362. [CrossRef]

40. Min, K.; Mundil, R.; Renne, P.R.; Ludwig, K.R. A test for systematic errors in ${ }^{40} \mathrm{Ar} /{ }^{39} \mathrm{Ar}$ geochronology through comparison of $\mathrm{U} / \mathrm{Pb}$ analysis of a $1.1 \mathrm{Ga}$ rhyolite. Geochim. Cosmochim. Acta 2000, 64, 73-98. [CrossRef] 
41. Duncan, R.A. A timeframe for construction of the Kerguelen Plateau and Broken Ridge. Special Issue on Kerguelen Plateau Drilling. J. Petrol. 2002, 43, 1109-1119. [CrossRef]

42. Reed, S.J.B.; Ware, N.G. Quantitative electron microprobe analysis of silicates using energy dispersive X-ray spectrometry. J. Petrol. 1975, 16, 499-519. [CrossRef]

43. Hart, S.R. Heterogeneous mantle domains: Signatures, genesis and mixing chronologies. Earth Planet. Sci. Lett. 1988, 90, 273-296. [CrossRef]

44. Norrish, K.; Hutton, J.T. An accurate X-ray spectrographic method for the analysis of a wide range of geological samples. Geochim. Cosmochim. Acta 1969, 33, 431-453. [CrossRef]

45. Robinson, P.; Townsend, A.T.; Yu, Z.; Munker, C. Determination of scandium, yttrium and rare earth elements in rocks by high resolution inductively coupled plasma-mass spectrometry. Geostand. Newsl. 1999, 23, 31-46. [CrossRef]

46. Yu, Z.; Robinson, P.; Townsend, A.T.; Munker, C.; Crawford, A.J. Determination of HFSE, Rb, Sr, Mo, Sb, Cs, Tl and Bi at ng g-1 levels in geological reference materials by magnetic sector ICP-MS after HF/HCLO4 high pressure digestion. Geostand. Newsl. 2000, 24, 39-50. [CrossRef]

47. Taras, B.D.; Hart, S.R. Geochemical evolution of the New England seamount chain: Isotopic and trace-element constraints. Chem. Geol. 1987, 64, 35-54. [CrossRef]

48. Pegram, W.J. Development of continental lithospheric mantle as reflected in the chemistry of the Mesozoic Appalachian tholeiites, USA. Earth Planet. Sci. Lett. 1990, 97, 316-331. [CrossRef]

49. Kennedy, A.K.; Hart, S.R.; Frey, F.A. Composition and isotopic constraints on the petrogenesis of alkaline arc lavas, Lihir Island, Papua New Guinea. J. Geophys. Res. 1990, 95, 6929-6942. [CrossRef]

50. Bindeman, I.N. Oxygen Isotopes in mantle and crustal magmas as revealed by single crystal analysis. Rev. Mineral. Geochem. 2008, 69, 445-478. [CrossRef]

51. Taneja, R.; O'Neill, C.; Lackie, M.; Rushmer, T.; Schmidt, P.; Jourdan, F. ${ }^{40} \mathrm{Ar} /{ }^{39} \mathrm{Ar}$ geochronology and the paleoposition of Christmas Island (Australia), Northeast Indian Ocean. Gondwana Res. 2015, 28, 391-406. [CrossRef]

52. Smith, W.C. The Volcanic rocks of Christmas Island (Indian Ocean). Q. J. Geol. Soc. Lond. 1926, 82, 44-66. [CrossRef]

53. Sobolev, A.V.; Hofmann, A.W.; Kuzmin, D.V.; Yaxley, G.M.; Arndt, N.T.; Chung, S.-L.; Danyushevsky, L.V.; Elliott, T.; Frey, F.A.; Garcia, M.O.; et al. The amount of recycled crust in sources of mantle-derived melts. Science 2007, 316, 412-417. [CrossRef]

54. Le Bas, M.J.; Le Maitre, R.W.; Streckeisen, A.; Zanettin, B. A chemical classification of volcanic rocks based on the total alkali-silica diagram. J. Petrol. 1986, 27, 745-750. [CrossRef]

55. Arevalo, R.; McDonough, W.F. Chemical variations and regional diversity observed in MORB. Chem. Geol. 2010, $271,70-85$. [CrossRef]

56. Jackson, M.G.; Dasgupta, R. Compositions of HIMU, EM1 and EM2 from global trends between radiogenic isotopes and major elements in ocean island basalts. Earth Planet. Sci. Lett. 2008, 276, 175-186. [CrossRef]

57. Barling, J.; Goldstein, S.L.; Nicholls, I.A. Geochemistry of Heard Island (Southern Indian Ocean): Characterization of an enriched mantle component and implications for enrichment of the sub-Indian Ocean mantle. J. Petrol. 1994, 35, 1017-1053. [CrossRef]

58. GeoROC. Geochemistry of Rocks of the Oceans and Continents. 2013. Available online: http://georoc.mpch-mainz.gwdg.de/ georoc/ (accessed on 1 December 2021).

59. Clague, D.A.; Holcomb, R.T.; Sinton, J.M.; Detrick, R.S.; Torresan, M.E. Pliocene and Pleistocene alkalic flood basalts on the seafloor north of the Hawaiian islands. Earth Planet. Sci. Lett. 1990, 98, 175-191. [CrossRef]

60. Sharaskin, A.Y.; Pustchin, I.K.; Zlobin, S.K.; Kolesov, G.M. Two ophiolite sequences from the basement of the northern Tonga arc Ofioliti 1983, 8, 411-430.

61. Falloon, T.J.; Danyushevsky, L.V.; Crawford, T.J.; Maas, R.; Woodhead, J.D.; Eggins, S.M.; Bloomer, S.H.; Wright, D.J.; Zlobin, S.K.; Stacey, A.R. Multiple mantle plume components involved in the petrogenesis of subduction-related lavas from the northern termination of the Tonga Arc and Lau Basin: Evidence from the geochemistry of arc and back-arc submarine volcanics. Geophys. Geochem. Geosys. 2007, 8, Q09003. [CrossRef]

62. Regelous, M.; Turner, S.; Falloon, T.J.; Taylor, P.; Gamble, J.; Green, T. Mantle dynamics and mantle melting beneath Niuafo'ou Island and the northern Lau back-arc basin. Contrib. Mineral. Petrol. 2008, 156, 103-118. [CrossRef]

63. Hirano, N.; Machida, S.; Sumino, H.; Shimizu, K.; Tamura, A.; Morishita, T.; Iwano, H.; Sakata, S.; Ishii, T.; Arai, S.; et al. Petit-spot volcanoes on the oldest portion of the Pacific plate. Deep-Sea Res. I 2019, 154, 103142. [CrossRef]

64. Willbold, M.; Stracke, A. Formation of enriched mantle components by recycling of upper and lower continental crust. Chem. Geol. 2010, 276, 188-197. [CrossRef]

65. Woodhead, J.D.; Greenwood, P.; Harmon, R.S.; Stoffers, P. Oxygen isotope evidence for recycled crust in the source of EM-type ocean island basalts. Nature 1993, 312, 809-813. [CrossRef]

66. Eisele, J.; Sharma, M.; Galer, S.J.G.; Blichert-Toft, J.; Devey, C.W.; Hofmann, A.W. The role of sediment recycling in EM-1 inferred from $\mathrm{Os}, \mathrm{Pb}, \mathrm{Hf}, \mathrm{Nd}$, Sr isotope and trace element systematics of the Pitcairn hotspot. Earth Planet. Sci. Lett. 2002, 196, 197-212. [CrossRef]

67. Jackson, M.G.; Hart, S.R.; Koppers, A.A.P.; Staudigel, H.; Konter, J.; Blusztajn, J.; Kurz, M.; Russell, J.A. The return of subducted continental crust in Samoan lavas. Nature 2007, 448, 684-687. [CrossRef]

68. Sun, S.-S.; McDonough, W.F. Chemical and isotopic systematics of oceanic basalts: Implications for mantle composition and processes. Geol. Soc. Lond. Spec. Publ. 1989, 42, 313-345. [CrossRef] 
69. Taneja, R.; Rushmer, T.; Blichert-Toft, J.; Turner, S.; O'Neill, C. Mantle heterogeneities beneath the Northeast Indian Ocean as sampled by intra-plate volcanism at Christmas Island. Lithos 2016, 262, 561-575. [CrossRef]

70. PetDB. Information System for Geochemical Data of Igneous and Metamorphic Rocks from the Ocean Floor. 2011. Available online: http:/ / www.earthchem.org/petdb (accessed on 1 December 2021).

71. Chakrabarti, R.; Basu, A.R.; Paul, D.K. Nd-Hf-Sr-Pb isotopes and trace element geochemistry of Proterozoic lamproites from southern India: Subducted komatiite in the source. Chem. Geol. 2007, 236, 291-302. [CrossRef]

72. Murphy, D.T.; Collerson, K.D.; Kamber, B.S. Lamproites from Gaussberg, Antarctica: Possible transition zone melts of Archaean subducted sediments. J. Petrol. 2002, 43, 981-1001. [CrossRef]

73. Fraser, K.J.; Hawkesworth, C.J.; Erlank, A.J.; Mitchell, R.H.; Scott-Smith, B.H. Sr, Nd and Pb isotope and minor element geochemistry of lamproites and kimberlites. Earth Planet. Sci. Lett. 1985, 76, 57-70. [CrossRef]

74. Rasoazanamparany, C.; Widom, E.; Kuentz, D.; Raharimahefa, T.; Rakotondravelo, K.; Rakotondrazafy, A.M.F. Geochemistry and mantle source characteristics of the Itasy volcanic field: Implications for the petrogenesis of basaltic magmas in intra-continentalrifts. Geochim. Cosmochim. Acta 2021, 300, 137-163. [CrossRef]

75. Machida, S.; Hirano, N.; Kimura, J.-I. Evidence for recycled plate material in Pacific upper mantle unrelated to plumes. Geochim. Cosmochim. Acta 2009, 73, 3028-3037. [CrossRef]

76. Workman, R.K.; Hart, S.R. Major and trace element composition of the depleted MORB mantle (DMM). Earth Planet. Sci. Lett. 2005, 231, 53-72. [CrossRef]

77. Salters, V.J.M.; Stracke, A. Composition of the depleted mantle. Geochem. Geophys. Geosyst. 2004, 5, Q05B07. [CrossRef]

78. Hanan, B.B.; Graham, D.W. Lead and helium isotope evidence from oceanic basalts for a common deep source of mantle plumes. Science 1996, 272, 991-995. [CrossRef]

79. Widom, E.; Hoernle, K.A.; Shirey, S.B.; Schmincke, H.U. Os isotope systematics in the Canary Islands and Madeira: Lithospheric contamination and mantle plume signatures. J. Petrol. 1999, 40, 279-296. [CrossRef]

80. Day, J.M.D. Hotspot volcanism and highly siderophile elements. Chem. Geol. 2013, 341, 50-74. [CrossRef]

81. Class, C.; Goldstein, S.L.; Shirey, S.B. Osmium isotopes in Grande Comore lavas: A new extreme among a spectrum of EM-type mantle endmembers. Earth Planet. Sci. Lett. 2009, 284, 219-227. [CrossRef]

82. Roy-Barman, M.; Allègre, C.J. ${ }^{187}$ Os $/{ }^{186}$ Os in oceanic island basalts: Tracing oceanic crust recycling in the mantle. Earth Planet. Sci. Lett. 1985, 129, 145-161. [CrossRef]

83. Schiano, P.; David, K.; Vlastélic, I.; Gannoun, A.; Klein, M.; Nauret, F.; Bonnand, P. Osmium isotope systematics of historical lavas from Piton de la Fournaise (Réunion Island, Indian Ocean). Contrib. Mineral. Petrol. 2012, 164, 805-820. [CrossRef]

84. Peters, B.J.; Day, J.M.D.; Taylor, L.A. Early mantle heterogeneities in the Reunion hotspot source inferred from highly siderophile elements in cumulate xenoliths. Earth Planet. Sci. Lett. 2016, 448, 150-160. [CrossRef]

85. Yang, H.-J.; Frey, F.A.; Weis, D.; Giret, A.; Pyle, D.; Michon, G. Petrogenesis of the flood basalts forming the Northern Kerguelen Archipelago: Implications for the Kerguelen Plume. J. Petrol. 1998, 39, 711-748. [CrossRef]

86. Workman, R.K.; Hart, S.R.; Jackson, M.; Regelous, M.; Farley, A.K.; Blusztajn, J.; Kurz, M.; Staudigel, H. Recycled metasomatized lithosphere as the origin of the Enriched Mantle II (EM2) end-member: Evidence from the Samoan Volcanic Chain. Geochem. Geophys. Geosyst. 2004, 5, Q04008. [CrossRef]

87. Jackson, M.G.; Shirey, S.B. Re-Os isotope systematics in Samoan shield lavas and the use of Os-isotopes in olivine phenocrysts to determine primary magmatic compositions. Earth Planet. Sci. Lett. 2011, 312, 91-101. [CrossRef]

88. Lassiter, J.C.; Blichert-Toft, J.; Hauri, E.H.; Barsczus, H.G. Isotope and trace element variations in lavas from Raivavae and Rapa, Cook-Austral islands: Constraints on the nature of HIMU- and EM-mantle and the origin of mid-plate volcanism in French Polynesia. Chem. Geol. 2003, 202, 115-138. [CrossRef]

89. Snortum, E.; Day, J.M.D.; Jackson, M.G. Pacific lithosphere evolution inferred from Aitutaki mantle xenoliths. J. Petrol. 2019, 60, 1753-1772. [CrossRef]

90. Chesley, J.; Righter, K.; Ruiz, J. Larger-scale mantle metasomatism: A Re-Os perspective. Earth Planet. Sci. Lett. 2004, 219, 49-60. [CrossRef]

91. Reisberg, L.; Zindler, A.; Marcantonio, F.; White, W.; Wyman, D.; Weaver, B. Os isotope systematics in ocean island basalts. Earth Planet. Sci. Lett. 1993, 120, 149-167. [CrossRef]

92. Hauri, E.H.; Hart, S.R. Re-Os isotope ystematics of HIMU and EMII oceanic island basalts from the south Pacific Ocean. Earth Planet. Sci. Lett. 1993, 114, 353-371. [CrossRef]

93. Hart, G.L.; Johnson, C.M.; Hildreth, W.; Shirey, S.B. New osmium isotope evidence for intracrustal recycling of crustal domains with discrete ages. Geology 2003, 31, 427-430. [CrossRef]

94. Mayer, B.; Jung, S.; Brauns, M.; Münker, C. The role of mantle-hybridization and crustal contamination in the petrogenesis of lithospheric mantle-derived alkaline rocks:constraints from Os and Hf isotopes. Contrib. Miner. Petrol. 2018, 173, 49. [CrossRef]

95. Schiano, P.; Burton, K.W.; Dupré, B.; Birck, J.-L.; Guille, G.; Allègre, C.J. Correlated Os-Pb-Nd-Sr isotopes in the Austral-Cook chain basalts: The nature of mantle components in plume sources. Earth Planet. Sci. Lett. 2001, 186, 527-537. [CrossRef]

96. Eiler, J.M.; Farley, K.A.; Valley, J.W.; Hauri, E.; Craig, H.; Hart, S.R.; Stolper, E.M. Oxygen isotope variations in ocean island basalt phenocrysts. Geochim. Cosmochim. Acta 1997, 61, 2281-2293. [CrossRef] 
97. Eiler, J.M. Oxygen isotope variations of basaltic lavas and upper mantle rocks. In Stable Isotope Geochemistry; Reviews in Mineralogy and Geochemistry; Valley, J.W., Cole, D.R., Eds.; Mineralogical Society of America: Washington, DC, USA, 2001; Volume 413, pp. 319-364.

98. Gaffney, A.M.; Nelson, B.K.; Reisberg, L.; Eiler, J. Oxygen-osmium isotope systematics of West Maui lavas: A record of shallowlevel magmatic processes. Earth Planet. Sci. Lett. 2005, 239, 122-139. [CrossRef]

99. Wang, Z.; Eiler, J.M. Insights into the origin of low $-\delta 18 \mathrm{O}$ basaltic magmas in Hawaii revealed from in situ measurements of oxygen isotope compositions of olivines. Earth Planet. Sci. Lett. 2008, 269, 377-387. [CrossRef]

100. Ito, E.; White, W.M.; Gopel, C. The O, Sr, Nd and Pb isotope geochemistry of MORB. Chem. Geol. 1987, 62, 157-174. [CrossRef]

101. Eiler, J.M.; Schiano, P.; Kitchen, N.; Stolper, E.M. Oxygen-isotope evidence for recycled crust in the sources of mid-ocean-ridge basalts. Nature 2000, 403, 530-534. [CrossRef] [PubMed]

102. Cooper, K.M.; Eiler, J.M.; Asimow, P.D.; Langmuir, C.H. Oxygen-isotope evidence for the origin of enriched mantle beneath the mid-Atlantic ridge. Earth Planet. Sci. Lett. 2004, 220, 297-316. [CrossRef]

103. Cooper, K.M.; Eiler, J.M.; Sims, K.W.; Langmuir, C.H. Distribution of recycled crust within the upper mantle: Insights from the oxygen isotope composition of MORB from the Australian-Antarctic Discordance. Geochim. Geophys. Geosyst. 2009, 10, Q12004. [CrossRef]

104. Bindeman, I.N.; Kamenetsky, V.S.; Palandri, J.; Vennemann, T. Hydrogen and oxygen isotope behaviors during variable degrees of upper mantle melting: Example from the basaltic glasses from Macquarie Island. Chem. Geol. 2012, 310-311, 126-136. [CrossRef]

105. Mattey, D.; Lowry, D.; Macpherson, C. Oxygen isotope compositions of mantle peridotite. Earth Planet. Sci. Lett. 1994, 128, 231-241. [CrossRef]

106. Eiler, J.M.; Farley, K.A.; Valley, J.W.; Stolper, E.M.; Hauri, E.H.; Craig, H. Oxygen isotope evidence against bulk recycled sediment in the mantle sources of Pitcairn Island lavas. Nature 1995, 377, 138-141. [CrossRef]

107. Sun, Y.; Ying, J.; Su, B.; Zhou, X.; Shao, J. Contribution of crustal materials to the mantle sources of Xiaogulihe ultrapotassic volcanic rocks, Northeast China: New constraints from mineral chemistry and oxygen isotopes of olivine. Chem. Geol. 2015, 405, 10-18. [CrossRef]

108. Day, J.M.D.; Pearson, D.G.; Macperson, C.G.; Lowry, D.; Carracedo, J.C. Pyroxenite-rich mantle formed by recycled oceanic lithosphere: Oxygen-osmium isotope evidence from Canary Islands. Geology 2009, 37, 555-558. [CrossRef]

109. Workman, R.K.; Eiler, J.M.; Hart, S.R.; Jackson, M.G. Oxygen isotopes in Samoan lavas: Confirmation of continental recycling Geology 2008, 36, 551-554. [CrossRef]

110. Taylor, H.P.; Turi, B.; Cundari, A. ${ }^{18} \mathrm{O} /{ }^{16} \mathrm{O}$ and chemical relationships in K-rich volcanic rocks from Australia, East Africa, Antarctica, and San Venanzo-Cupaello, Italy. Earth Planet. Sci. Lett. 1984, 69, 273-276. [CrossRef]

111. Downes, H.; Kempton, P.D.; Briot, D.; Harmon, R.S.; Leyreloup, A.F. Pb and Os isotope systematics in granulite facies xenoliths, French Massif Central: Implications for crustal processes. Earth Planet. Sci. Lett. 1991, 102, 342-357. [CrossRef]

112. Kempton, P.D.; Harmon, R.S. Oxygen isotope evidence for large-scale hybridization of the lower crust during magmatic underplating. Geochim. Cosmochim. Acta 1992, 56, 971-986. [CrossRef]

113. Hirano, N.; Koppers, A.A.P.; Takahashi, A.; Fujiwara, T.; Nakanishi, M. Seamounts, knolls and petit-spot monogenetic volcanoes on the subducting Pacific plate. Basin Res. 2008, 20, 543-553. [CrossRef]

114. Yamamoto, J.; Korenaga, J.; Hirano, N.; Kagi, H. Melt-rich lithosphere-asthenosphere boundary inferred from petit-spot volcanoes Geology 2014, 42, 967-970. [CrossRef]

115. Machida, S.; Hirano, N.; Sumino, H.; Hirata, T.; Yoneda, S.; Kato, Y. Petit-spot geology reveals melts in upper-most asthenosphere dragged by lithosphere. Earth Planet. Sci. Lett. 2015, 426, 267-279. [CrossRef]

116. Yamamoto, J.; Hirano, N.; Kurz, M.D. Noble gas isotopic compositions of seamount lavas from the central Chile trench: Implications for petit-spot volcanism and the lithosphere asthenosphere boundary. Earth Planet. Sci. Lett. 2020, 552, 116611. [CrossRef]

117. Korenaga, J. Plate tectonics and surface environment: Role of the oceanic upper mantle. Earth-Sci. Rev. 2020, 205, 103185. [CrossRef]

118. Green, D.H.; Liebermann, R.C. Phase equilibria and elastic properties of a pyrolite model for the oceanic upper mantle. Tectonophysics 1976, 32, 61-92. [CrossRef]

119. Niu, Y.; Green, D.H. The petrological control on the lithosphere-asthenosphere boundary (LAB) beneath ocean basins. Earth -Sci. Rev. 2018, 185, 301-307. [CrossRef]

120. Gardés, E.; Laumonier, M.; Massuyeau, M.; Gaillard, F. Unravelling partial melt distribution in the oceanic low velocity zone. Earth Planet. Sci. Lett. 2020, 116242. [CrossRef]

121. Kovacs, I.J.; Liptai, N.; Koptev, A.; Cloetingh, S.A.P.L.; Lange, T.P.; Matenco, L.; Szakacs, A.; Radulian, M.; Berkesi, M.; Patko, L.; et al. The 'pargasosphere' hypothesis: Looking at global plate tectonics from a new perspective. Glob. Planet. Chang. 2021, 204, 103547. [CrossRef]

122. Sheppard, S.; Taylor, W.R. Barium- and LREE-rich, olivine-mica-lamprophres with affinities to lamproites, Mt Bundey, Northern Territory, Australia. Lithos 1992, 28, 303-325. [CrossRef]

123. Fraser, K.J.; Hawkesworth, C.J. The petrogenesis of group 2 ultrapotassic kimberlites from Finsch Mine, South Africa. Lithos 1992, 28, 327-345. [CrossRef] 
124. Rao, N.V.C. Chelima dykes, Cuddapah Basin, Southern India: A review of the age, petrology, geochemistry and petrogenesis of World's oldest lamproites. J. Geol. Soc. India 2007, 69, 523-538.

125. Homrighausen, S.; Hoernle, K.; Geldmacher, J.; Wartho, J.-A.; Hauff, F.; Portnyagin, M.; RWerner, R.; van den Bogaard, P.; Garbe-Schönberg, D. Unexpected HIMU-type late-stage volcanism on the Walvis Ridge. Earth Planet. Sci. Lett. 2018, 492, 251-263. [CrossRef]

126. Pelleter, A.-A.; Caroff, M.; Cordier, C.; Bachelery, P.; Nehlig, P.; Debeuf, D.; Arnaud, N. Melilite-bearing lavas in Mayotte (France): An insight into the mantle source below the Comores. Lithos 2014, 208-209, 281-297. [CrossRef]

127. Melluso, L.; le Roex, A.P.; Morra, V. Petrogenesis and Nd-Pb-Sr- isotope geochemistry of the olivine melilitites and olivine nephelinites ("ankaratrites") in Madagascar. Lithos 2011, 127, 505-521. [CrossRef]

128. Rogers, N.W.; Hawkesworth, C.J.; Palacz, Z.A. Phlogopite in the generation of olivine-melilitites from Namaqualand, South Africa and implications for element fractionation processes in the upper mantle. Lithos 1992, 28, 347-365. [CrossRef]

129. Hirano, N.; Kawamura, K.; Hattori, M.; Saito, K.; Ogawa, Y. A new type of intra-plate volcanism; young alkali-basalts discovered from the subducting Pacific Plate, northern Japan Trench. Geophys. Res. Lett. 2001, 28, 2719-2722. [CrossRef]

130. Green, D.H.; Falloon, T.J. Pyrolite: A Ringwood concept and its current expression. In The Earth's Mantle: Structure, Composition and Evolution; Jackson, I., Ed.; Cambridge University Press: Cambridge, UK, 1998; pp. 311-378.

131. Green, D.H.; Falloon, T.J. Primary magmas at mid-ocean ridges, "hotspots" and other intraplate settings: Constraints on mantle potential temperature. In Plates, Plumes, and Paradigms; Foulger, G.R., Natland, J.H., Presnall, D.C., Anderson, D.L., Eds.; Geological Society of America, Special Publication: Boulder, CO, USA, 2005; Volume 388, pp. 217-247.

132. Green, D.H.; Hibberson, W.O.; Kovacs, I.; Rosenthal, A. Water and its influence on the lithosphere-asthenosphere boundary. Nature 2010, 467, 448-451. [CrossRef] [PubMed]

133. Richards, F.D.; Hoggard, M.J.; Cowton, L.R.; White, N.J. Reassessing the thermal structure of oceanic lithosphere with revised global inventories of basement depths and heat flow measurements. J. Geophys. Res. Solid Earth 2018, 123, 9136-9161. [CrossRef]

134. Steinberger, B.; Becker, T.W. A comparison of lithospheric thickness models. Tectonophysics 2018, 746, 325-338. [CrossRef]

135. Auer, L.; Becker, T.W.; Boschi, L.; Schmerr, N. Thermal structure, radial anisotropy, and dynamics of oceanic boundary layers. Geophys. Res. Lett. 2015, 42, 9740-9749. [CrossRef]

136. Danyushevsky, L.V.; Plechov, P. Petrolog3: Integrated software for modeling crystallization processes. Geochem. Geophys. Geosyst. 2011, 12, Q07021. [CrossRef]

137. Ballhaus, C.; Berry, R.F.; Green, D.H. Oxygen fugacity controls in the Earth's upper mantle. Nature 1990, 348, 437-440. [CrossRef]

138. Herzberg, C.; O'Hara, M.J. Plume-associated ultramafic magmas of Phanerozoic age. J. Petrol. 2002, 43, 1857-1883. [CrossRef]

139. Borisov, A.A.; Shapkin, A.I. A new empirical equation rating $\mathrm{Fe} 3+/ \mathrm{Fe} 2+$ in magmas to their composition, oxygen fugacity, and temperature. Geochem. Int. 1990, 27, 111-116.

140. Dixon, J.; Clague, D.A.; Cousens, B.; Monsalve, M.L.; Uhl, J. Carbonatite and silicate melt metasomatism of the mantle surrounding the Hawaiian plume: Evidence from volatiles, trace elements, and radiogenic isotopes in rejuvenated stage lavas from Niihau, Hawaii. Geochem. Geophys. Geosyst. 2008, 9, Q09005. [CrossRef]

141. Shimizu, K.; Ito, M.; Chang, Q.; Miyazaki, T.; Ueki, K.; Toyama, C.; Senda, R.; Vaglarov, B.S.; Ishikawa, T.; Kimura, J.-I. Identifying volatile mantle trend with the water-fluorine-cerium systematics of basaltic glass. Chem. Geol. 2019, 522, 283-294. [CrossRef]

142. Rosenthal, A.; Hauri, E.H.; Hirschmann, M. Experimental determination of C, F, and $\mathrm{H}$ partitioning between mantle minerals and carbonated basalt, $\mathrm{CO}_{2} / \mathrm{Ba}$ and $\mathrm{CO}_{2} / \mathrm{Nb}$ systematics of partial melting, and the $\mathrm{CO}_{2}$ contents of basaltic source regions. Earth Planet. Sci. Lett. 2015, 425, 77-87. [CrossRef]

143. Aubaud, C.; Pineau, F.; Hekinian, R.; Javoy, M. Degassing of $\mathrm{CO}_{2}$ and $\mathrm{H}_{2} \mathrm{O}$ in submarine lavas from the Society hotspot. Earth Planet. Sci. Lett. 2005, 235, 511-527. [CrossRef]

144. Boudoire, G.; Rizzo, A.L.; Muro, A.D.; Grassa, F.; Liuzzo, M. Extensive $\mathrm{CO}_{2}$ degassing in the upper mantle beneath oceanic basaltic volcanoes: First insights from Piton de la Fournaise volcano (La Réunion Island). Geochim. Cosmochim. Acta 2018, 235, 376-401. [CrossRef]

145. Moore, L.R.; Gazel, E.; Bodnar, R.J. The volatile budget of Hawaiian magmatism: Constraints from melt inclusions from Haleakala volcano, Hawaii. J. Volcanol. Geotherm. Res. 2021, 410, 107144. [CrossRef]

146. Bultitude, R.J.; Green, D.H. Experimental study at high pressures on the origin of olivine-nephelinite and olivine-melilitenephelenite magmas. Earth Planet. Sci. Lett. 1968, 3, 325-337. [CrossRef]

147. Green, D.H. Conditions of melting of basanite magma from garnet peridotite. Earth Planet. Sci. Lett. 1973, 17, 456-465. [CrossRef]

148. Brey, G.P.; Green, D.H. Systematic study of liquidus phase relations in olivine melilitite $+\mathrm{H}_{2} \mathrm{O}+\mathrm{CO}_{2}$ at high pressures and petrogenesis of an olivine melilitite magma. Contrib. Mineral. Petrol. 1977, 61, 141-162. [CrossRef]

149. Adam, J. The geochemistry and experimental petrology of sodic alkaline basalts from Oatlands, Tasmania. J. Petrol. 1990, 31, 1201-1223. [CrossRef]

150. Hirschmann, M.M. Partial melt in the oceanic low velocity zone. Phys. Earth Planet. Inter. 2010, 179, 60-71. [CrossRef]

151. Dasgupta, R.; Hirschmann, M.M.; Smith, N.D. Partial melting experiments of peridotite+CO $\mathrm{CO}_{2}$ at $3 \mathrm{GPa}$ and genesis of alkalic ocean island basalts. J. Petrol. 2007, 48, 2093-2124. [CrossRef]

152. Forbes, W.C.; Staarmer, R.J. Kaersutite is a possible source of alkali olivine basalts. Nature 1974, 250, 209-210. [CrossRef]

153. Pilet, S.; Baker, M.B.; Stolper, E.M. Metasomatized lithosphere and the origin of alkaline lavas. Science 2008, 320, 916-919. [CrossRef] 
154. Green, D.H.; Hibberson, W.O.; Rosenthal, A.; Kovacs, I.; Yaxley, G.M.; Falloon, T.J.; Brink, F. Experimental study of the influence of water on melting and phase assemblages in the upper mantle. J. Petrol. 2014, 55, 2067-2096. [CrossRef]

155. Falloon, T.J.; Green, D.H.; Hatton, C.J.; Harris, K.L. Anhydrous partial melting of a fertile and depleted peridotite from 2 to 30 kbars and application to basalt petrogenesis. J. Petrol. 1988, 29, 1257-1282. [CrossRef]

156. Gurenko, A.A.; Geldmacher, J.; Hoernle, K.A.; Sobolev, A.V. A composite, isotopically-depleted peridotite and enriched pyroxenite source for Madeira magmas: Insights from olivine. Lithos 2013, 170-171, 224-238. [CrossRef]

157. Falloon, T.J.; Green, D.H.; Danyushevsky, L.V. Crystallization temperatures of tholeiite parental liquids: Implications for the existence of thermally driven mantle plumes. In Plates, Plumes, and Planetary Processes; Geological Society of America Special Paper; Foulger, G.R., Jurdy, D.M., Eds.; Geological Society of America: Boulder, CO, USA, 2007; Volume 430, pp. 235-260. [CrossRef]

158. Stein, C.A.; Stein, S. A model for the global variation in oceanic depth and heat flow with lithospheric age. Nature 1992, 359, 123-129. [CrossRef]

159. Asimov, P.D.; Hirschmann, M.M.; Stolper, E.M. Calculation of peridotite partial melting from thermodynamic models of minerals and melts, IV. Adiabatic decompression and the composition and mean properties of mid-ocean ridge basalts. J. Petrol. 2001, 42, 963-998. [CrossRef]

160. Grose, C.J.; Afonso, J.C. Comprehensive plate models for the thermal evolution of oceanic lithosphere. Geochem. Geophys. Geosyst. 2013, 14, 3751-3778. [CrossRef]

161. Sarafian, E.; Gaetani, G.A.; Hauri, E.H.; Sarafian, A.R. Experimental constraints on the damp peridotite solidus and oceanic mantle potential temperature. Science 2017, 355, 943-945. [CrossRef] [PubMed]

162. Machida, S.; Kogiso, T.; Hirano, N. Petit-spot as definitive evidence for partial melting in the asthenosphere caused by $\mathrm{CO}_{2}$. Nat Commun. 2017, 8, 14302. [CrossRef] [PubMed]

163. Hart, S.R.; Zindler, A. In search of a bulk-Earth composition. Chem. Geol. 1986, 57, 247-267. [CrossRef]

164. Geldmacher, J.; Hoernle, K.; Klügel, A.; Bogaard, P.V.D.; Wombacher, F.; Berning, B. Origin and geochemical evolution of the Madeira-Tore Rise (eastern North Atlantic). J. Geophys. Res. 2006, 111, B09206. [CrossRef]

165. Hoernle, K.; Carracedo, J.C. Canary Islands, geology. In Encyclopedia of Islands; Gillespie, R.G., Clague, D.A., Eds.; University of California Press: Berkeley, CA, USA, 2009; pp. 133-143.

166. Jackson, M.G.; Weis, D.; Huang, S. Major element variations in Hawaiian shield lavas: Source features and perspectives from global ocean island basalt (OIB) systematics. Geochem. Geophys. Geosyst. 2012, 13, Q09009. [CrossRef]

167. Eggins, S.M. Petrogenesis of Hawaiian tholeiites: 1. Phase equilibria constraints. Contrib. Mineral. Petrol. 1992, 110, $387-397$. [CrossRef]

168. Humphreys, E.R.; Niu, Y.L. On the composition of ocean island basalts (OIB): The effects of lithospheric thickness variation and mantle metasomatism. Lithos 2009, 112, 118-136. [CrossRef]

169. Trela, J.; Gazel, E.; Sobolev, A.V.; Moore, L.; Bizimis, M.; Jicha, B.; Batanova, V.G. The hottest lavas of the Phanerozoic and the survival of deep Archaean reservoirs. Nat. Geosci. 2017, 10, 451-458. [CrossRef]

170. Parsons, A.J.; Sigloch, K.; Hosseini, K. Australian plate subduction is responsible for Northward motion of the India-Asia collision zone and $\sim 1000 \mathrm{~km}$ lateral migration of the Indian Slab. Geophys. Res. Lett. 2021, 48, e2021GL094904. [CrossRef]

171. Pyle, D.G.; Christie, D.M.; Mahoney, J.J. Resolving an isotopic boundary within the Australian-Antarctic discordance. Earth Planet. Sci. Lett. 1992, 112, 161-178. [CrossRef]

172. Stracke, A.; Bizimis, M.; Salters, V.J.M. Recycling oceanic crust: Quantitative constraints. Geochem. Geophys. Geosyst. 2003, 4, 8003. [CrossRef]

173. Janney, P.E.; Le Roex, A.P.; Carlson, R.W.; Viljoen, K.S. A chemical and multi-isotope study of the Western Cape Olivine Melilitite Province, South Africa: Implications for the sources of kimberlites and the origin of the HIMU signature in Africa. J. Petrol. 2002, 43, 2339-2370. [CrossRef]

174. Meyzen, C.M.; Blichert-Toft, J.; Ludden, J.N.; Humler, E.; Mével, C.; Albarède, F. Isotopic portrayal of the arth's upper mantle flow field. Nature 2007, 447, 1069-1074. [CrossRef] [PubMed]

175. Homrighausen, S.; Hoernle, L.; Zhou, H.; Geldmacher, J.; Wartho, J.-A.; Hauff, F.; Werner, R.; Jumg, S.; Morgan, J.P. Paired EMI-HIMU hotspots in the South Atlantic-starting plume heads trigger compositionally distinct secondary plumes? Sci. Adv. 2020, 6, eaba0282. [CrossRef] [PubMed]

176. Liu, J.; Pearson, D.G.; Wang, L.H.; Mather, K.A.; Kjarsgaard, B.A.; Schaeffer, A.J.; Irvine, G.J.; Kopylova, M.G.; Armstrong, J.P. Plume-driven recratonization of deep continental lithospheric mantle. Nature 2021, 592, 732-736. [CrossRef]

177. Panza, G.; Doglioni, C.; Levshin, A. Asymmetric ocean basins. Geology 2010, 38, 59-62. [CrossRef]

178. Doglioni, C.; Panza, G.F. Polarized plate tectonics. Adv. Geophys. 2015, 56, 1-167. [CrossRef]

179. Chalot-Prat, F.; Doglioni, C.; Falloon, T. Westward migration of oceanic ridges and related asymmetric upper mantle differentiation. Lithos 2017, 268-271, 163-173. [CrossRef]

180. Jackson, M.G.; Becker, T.W.; Konter, J.G. Evidence for a deep mantle source for EM and HIMU domains from integrated geochemical and geophysical constraints. Earth Planet. Sci. Lett. 2018, 484, 154-167. [CrossRef]

181. Storey, M.; Saunders, A.D.; Tarney, J.; Gibson, I.L.; Norry, M.J.; Thirlwall, M.F.; Leat, P.; Thompson, R.N.; Menzies, M.A. Contamination of Indian Ocean asthenosphere by the Kerguelen-Heard mantle plume. Nature 1989, 338, 574-576. [CrossRef] 
182. Hofmann, A.W.; Jochum, K.P.; Suefert, M.; White, W.M. Nb and Pb in oceanic basalts: New constraints on mantle evolution. Earth Planet. Sci. Lett. 1986, 79, 33-45. [CrossRef]

183. Hofmann, A.W. Chemical differentiation of the Earth: The relationship between mantle, continental crust, and oceanic crust. Earth Planet. Sci. Lett. 1988, 90, 297-314. [CrossRef]

184. Hofmann, A.W. Sampling mantle heterogeneity through oceanic basalts: Isotopes and trace elements. In The Mantle and Core; Treatise on Geochemistry; Carlson, R.W., Ed.; Elsevier-Pergamon: Oxford, UK, 2003; Volume 2, pp. 61-101.

185. Sims, K.W.; DePaolo, D.J. Inferences about the mantle magma sources from incompatible element concentration ratios in oceanic basalts. Geochim. Cosmochim. Acta 1997, 61, 765-784. [CrossRef]

186. Widom, E.; Shirey, S.B. Os isotope systematics in the Azores: Implications for mantle plume sources. Earth Planet. Sci. Lett. 1996, $142,451-465$.

187. Escrig, S.; Campas, F.; Dupré, B.; Allègre, C.J. Osmium isotopic constraints on the nature of the DUPAL anomaly from Indian mid-ocean-ridge basalts. Nature 2004, 431, 59-63. [CrossRef] [PubMed]

188. Rudnick, R.L.; Gao, S. Composition of the continental crust. In The Mantle and Core; Treatise on Geochemistry; Carlson, R.W., Ed.; Elsevier-Pergamon: Oxford, UK, 2003; Volume 2, pp. 1-64.

189. Saha, A.; Hazra, A.; Santosh, M.; Ganguly, S.; Li, S.-S.; Manikyamba, C. Episodic recycling of ancient metasomatized continental lithosphere: Evidence from lower oceanic crust of the Central Indian Ridge. Lithos 2021, 400-401, 106424. [CrossRef]

190. Mahoney, J.; Le Roex, A.P.; Peng, Z.; Fisher, R.L.; Natland, J.H. Southwestern limits of Indian Ocean Ridge Mantle and the Origin of Low ${ }^{206} \mathrm{~Pb} /{ }^{204} \mathrm{~Pb}$ in Mid-Ocean Ridge Basalt- Isotope systematics of the Central Southwest Indian Ridge $\left(17^{\circ}-50^{\circ} \mathrm{E}\right)$. J. Geophys. Res. 1992, 97, 19771-19790. [CrossRef]

191. Douglass, J.; Schilling, J.-G. Systematics of three-component, pseudo-binary mixing lines in 2D isotope ratio space representations and implications for mantle plume-ridge interaction. Chem. Geol. 2000, 163, 1-23. [CrossRef]

192. Meyzen, C.M.; Ludden, J.N.; Humler, E.; Luais, B.; Toplis, M.J.; Mevel, C.; Storey, M. New insights into the origin and distribution of the DUPAL isotope anomaly in the Indian Ocean mantle from MORB of the Southwest Indian Ridge. Geochem. Geophys. Geosyst. 2005, 6, Q11K11. [CrossRef]

193. Schwindrofska, A.; Hoernle, K.; Hauff, F.; van den Bogaard, P.; Werner, R.; Garbe-Schönberg, D. Origin of enriched components in the South Atlantic: Evidence from 40 Ma geochemical zonation of the Discovery Seamounts. Earth Planet. Sci. Lett. 2016, 441 , 167-177. [CrossRef]

194. Homrighausen, S.; Hoernle, L.; Wartho, J.-A.; Hauff, F.; Werner, R. Do the $85^{\circ}$ E Ridge and Conrad Rise form a hotspot track crossing the Indian Ocean? Lithos 2021, 398-399, 106234. [CrossRef]

195. Konter, J.G.; Becker, T.W. Shallow lithospheric contribution to mantle plumes revealed by integrating seismic and geochemical data. Geochem. Geophys. Geosyst. 2012, 13, Q02004. [CrossRef]

196. Hart, S.R.; Staudigel, H. Isotopic characterization and identification of recycled components. In Crust/Mantle Recycling at Convergence Zones; Hart, S.R., Gülen, L., Eds.; NATO ASI Series (Series C: Mathematical and Physical Sciences); Springer: Dordrecht, The Netherlands, 1989; Volume 258. [CrossRef]

197. DePaolo, D.J.; Manton, W.I.; Grew, E.S.; Halpern, H. Sm-Nd, Rb-Sr and U-Th-Pb systematics of granulite facies rocks from Fyfe Hills, Enderby Land, Antarctica. Nature 1982, 298, 614-618. [CrossRef]

198. Kempton, P.D.; Harmon, R.S.; Hawkesworth, C.J.; Moorbath, S. Petrology and geochemistry of lower crustal granulites from the Geronimo Volcanic Field, southeastern Arizona. Geochim. Cosmochim. Acta 1990, 54, 3401-3426. [CrossRef]

199. Rudnick, R.L.; Goldstein, S.L. The Pb isotopic compositions of lower crustal xenoliths and the evolution of lower crustal Pb. Earth Planet. Sci. Lett. 1990, 98, 192-207. [CrossRef]

200. Cameron, K.L.; Robinson, J.V.; Niemeyer, S.; Nimz, G.J.; Kuentz, D.C.; Harmon, R.S.; Bohlen, S.R.; Collerson, K.D. Contrasting styles of pre-Cenozoic and mid-Tertiary crustal evolution in northern Mexico: Evidence from deep crustal xenoliths from La Olivina. J. Geophys. Res. 1992, 97, 17353-17376. [CrossRef]

201. Lucassen, F.; Lewerenz, S.; Franz, G.; Viramonte, J.; Mezger, K. Metamorphism, isotopic ages and composition of lower crustal granulite xenoliths from the Cretaceous Salta Rift, Argentina. Contrib. Miner. Petrol. 1999, 134, 325-341. [CrossRef]

202. Grimes, K.G. Karst features of Christmas Islands. Helictite 2001, 37, 41-58.

203. Andrews, C.W. A Monograph of Christmas Island (Indian Ocean) Physical Features and Geology; British Museum (Natural History): London, UK, 1900.

204. Trueman, N.A. The phosphate, volcanic and carbonate rocks of Christmas Island (Indian Ocean). J. Geol. Soc. Aust. 1965, 12, 261-283. [CrossRef]

205. Barrett, P.J. Christmas Island (Indian Ocean) phosphate deposits. In Phosphate Deposits of the World; Phosphate Rock Resources; Notholt, A.J.G., Sheldon, R.P., Davidson, D.F., Eds.; Cambridge University Press: Cambridge, UK, 1989; Volume 2, pp. $558-563$.

206. Polak, E.J. Christmas Island (Indian Ocean), geophysical survey for groundwater, 1973. Bur. Miner. Resour. Geol. Geophys. Aust. Record 1976, 100, 13520.

207. Shirey, S.B.; Walker, R.J. Carius tube digestion for low-blank rhenium-osmium analysis. Anal. Chem. 1995, 67, $2136-2141$. [CrossRef]

208. Cohen, A.S.; Waters, F.G. Separation of osmium from geological materials by solvent extraction for analysis by thermal ionization mass spectrometry. Anal. Chim. Acta 1996, 332, 269-275. [CrossRef] 
209. Bezard, R.; Turner, S.; Schaefer, B.; Yogodzinski, G.; Hoernle, K. Os isotopic composition of western Aleutian adakites: Implications for the Re/Os of oceanic crust processed through hot subduction zones. Geochim. Cosmochim. Acta 2021, 292, 452-467. [CrossRef]

210. Day, J.M.; Waters, C.L.; Schaefer, B.F.; Walker, R.J.; Turner, S. Use of hydrofluoric acid desilicification in the determination of highly siderophile element abundances and Re-Pt-Os isotope systematics in magic-ultramafic rocks. Geostand. Geoanal. Res. 2016, 40, 49-65. [CrossRef]

211. Falloon, T.J.; Green, D.H.; Jacques, A.L.; Hawkins, J.W. Refractory magmas in back-arc basin settings-experimental constraints on the petrogenesis of a Lau Basin example. J. Petrol. 1999, 40, 255-277. [CrossRef]

212. Amante, C.; Eakins, B.W. ETOPO1 1 arc-minute global relief model: Procedures, data sources and analysis. In NOAA Technical Memorandum NESDIS NGDC-24; National Geophysical Data Center: Boulder, CO, USA, 2009.

213. Nuttall, W.L.F. A revision of the orbitoides of Christmas Island (Indian Ocean). Q. J. Geol. Soc. Lond. 1926, 82, 22-43. [CrossRef]

214. Ludbrook, N.H. Tertiary fossils from Christmas Island (Indian Ocean). J. Geol. Soc. Aust. 1965, 12, 285-294. [CrossRef]

215. Adams, C.G.; Belford, D.J. Formaniferal biostratigraphy of the Oligocene-Miocene limestones of Christmas Island (Indian Ocean). Paleontology 1974, 17, 475-506.

216. Haq, B.U.; Hardenbol, J.; Vail, P.R. Chronology of fluctuating sea levels since the Triassic. Science 1987, 235, 1156-1167. [CrossRef]

217. Woodriffe, C.D. Vertical movement of isolated oceanic islands at plate margins evidence from emergent reefs in Tonga (Pacific Ocean), Cayman islands (Caribbean Sea) and Christmas Island (lndian Ocean). Z. Geomorph. Suppl.-Bd. 1988, 69, 17-37.

218. Korsch, M.J.; Gulson, B.L. Nd and Pb isotopic studies of an Archaean layered mafic-ultramafic complex, Western Australia, and implications for mantle heterogeneity. Geochim. Cosmochim. Acta 1986, 50, 1-10. [CrossRef]

219. Borisova, A.Y.; Belyatsky, B.V.; Portnyagin, M.V.; Sushchevskaya, N.M. The petrogenesis of olivine-phyric basalts from the Aphanasey Nikitin Rise: Evidence for contamination by cratonic lower continental crust. J. Petrol. 2001, 43, 277-319. [CrossRef]

220. Geldmacher, J.; Hoernle, K.; Klügel, A.; van den Bogaard, P.; Bindeman, I. Geochemistry of a new enriched mantle type locality in the northern hemisphere: Implications for the origin of the EM-I source. Earth Planet. Sci. Lett. 2008, 265, 167-182. [CrossRef]

221. Mahoney, J.J.; Frei, R.; Tejada, M.L.G.; Mo, X.X.; Leat, P.T.; Nagler, T.F. Tracing the Indian Ocean mantle domain through time: Isotopic results from old West Indian, East Tethyan, and South Pacific seafloor. J. Petrol. 1998, 39, 1285-1306. [CrossRef]

222. Falloon, T.J.; Varne, R.; Morris, J.D.; Hart, S.R. Alkaline lavas from Christmas Island and Nearby seamounts: Magmatism of the northeastern Indian Ocean. In Continental Magmatism, Abstracts, International Association of Volcanology and Chemistry of the Earth's Interior, Santa Fe, Bulletin 131; New Mexico Bureau of Mines and Mineral Resources: Socorro, NM, USA, 1989 ; p. 86. 